$$
\text { UNIVERSIDADE DE SÃO PAULO }
$$

FACULDADE DE FILOSOFIA, LETRAS E CIÊNCIAS HUMANAS

DEPARTAMENTO DE LETRAS MODERNAS

PROGRAMA DE PÓS-GRADUAÇÃO EM LETRAS

(LÍNGUA ESPANHOLA E LITERATURAS ESPANHOLA E HISPANO-AMERICANA)

MARIA DE LOS ANGELES DE CASTRO BALLESTEROS

$Y$ si esta não for uma Oração Condicional?

A (não) influência do contexto e da instrução formal na compreensão de um enunciado complexo

Versão original

SÃO PAULO

2019 


\section{Y si esta não for uma Oração Condicional? A (não) influência do contexto e da instrução formal na compreensão de um enunciado complexo}

Versão original

Dissertação de mestrado apresentada ao Programa de Pós-Graduação em Letras (Língua Espanhola e Literaturas Espanhola e Hispano-Americana) do Departamento de Letras Modernas da Faculdade de Filosofia, Letras e Ciências Humanas da Universidade de São Paulo, como requisito parcial para a obtenção do título de Mestre em Letras.

Orientadora: Profa. Drạ. Fátima A. T. Cabral Bruno

SÃO PAULO

2019 
BALLESTEROS, M.A.C. $Y$ si esta não for uma Oração Condicional? A (não) influência do contexto e da instrução formal na compreensão de um enunciado complexo. Dissertação apresentada à Faculdade de Filosofia, Letras e Ciências Humanas da Universidade de São Paulo, para obtenção do título de Mestre em Letras.

Aprovada em:

Banca examinadora

Profa. Drạ.

Instituição:

Julgamento:

Assinatura:

Profa. Drạ.

Instituição:

Julgamento:

Assinatura:

Profa. Dra .

Instituição:

Julgamento:

Assinatura: 


\section{DEDICATÓRIA}

Mais que a capacidade intelectual, é fundamental ter a oportunidade de compartilhar espaços e experiências que permitem aprender. Por isso, ofereço, com carinho e muito orgulho, este trabalho a todos aqueles que, de alguma forma, me possibilitaram usufruir momentos de aprendizagem, em especial à professora Fátima. Mais que orientadora, grande mestra e amiga confidente, em sua forma de ser e ensinar, reflete as palavras de Paulo Freire: “A alegria não chega apenas no encontro do achado, mas faz parte do processo da busca. E ensinar e aprender não pode dar-se fora da procura, fora da boniteza e da alegria". 


\section{AGRADECIMENTOS}

Esta pós-graduação é a realização de um sonho, perseguido por cinco anos. Depois que me formei, na segunda graduação, decidi que não seria outro o Mestrado, se não o de Letras da Universidade de São Paulo (USP). Acreditei, insisti e consegui! Mas tenho a convicção de que chegar até aqui, além de meu esforço pessoal, foi uma benção e a conjunção de uma série de acontecimentos que, certamente, foram articulados por uma energia maior. Por isso, agradeço, antes de tudo ao Pai do Céu.

E se somos fruto de nossas histórias e memórias, devo muito do que sou a meus pais, Fernando e Pepita, meus filhos, Raphael e Bárbara, e aos amigos, que felizmente, não são poucos e são muito bons! Tem uma amiga, em especial, a quem devo meu afastamento no trabalho, o que possibilitou fazer o curso em São Paulo, morando a $350 \mathrm{~km}$ de distância: à Réka, por toda sua torcida e alegria, quando fui aprovada na seleção do Programa, e sua disponibilidade e boa-vontade em me "cobrir" no trabalho, muito, muito obrigada!

Minha escolha pelo mestrado no programa de Letras-Espanhol da USP foi, na verdade, consequência da minha admiração por aquela que eu desejei ter como orientadora - a professora Fátima Cabral Bruno, a quem quero declarar que nestes anos de convivência e trocas minha admiração só fez crescer. Obrigada, por sua generosidade, conselhos, compreensão e amizade. Papai do Céu foi bom demais comigo!

Na minha trajetória acadêmica, agradeço aos professores da Graduação, em especial àquelas que se tornaram amigas-irmãs Rosângela Borges e Katia Oliveira, quem me orientou e incentivou no caminho da pesquisa. Durante o Mestrado, tive o privilégio de compartilhar momentos de discussão enriquecedores e de conviver com as professoras Maria Angélica Mendes, da UNIFAL-MG, Zilda Aquino e Maria Lúcia Victório às quais agradeço por suas importantes contribuições à minha pesquisa. Também agradeço aos colegas que compartilharam suas leituras e reflexões, especialmente o Alexandre, orientando da professora Zilda, pela observação referente à influência da imagem na compreensão. Gratidão!

Às professoras Maria Lúcia da C. Victório de Oliveira Andrade e Maria Zulma M. Kulilowski, gratidão por suas palavras de incentivo e contribuições a este trabalho, como componentes da banca de Qualificação e agora, mais uma vez, generosas e disponíveis em minha Banca de Defesa. Por esta, incluo meu agradecimento à professora Kátia Oliveira, que se dispôs a me acompanhar, agora, no desdobramento daquela nossa primeira pesquisa.

Muchas gracias às professoras Jacqueline Lopes, da E.E. Dr. Emílio da Silveira, e Priscila Navarro, do projeto Idiomas sem Fronteiras, pelas horas de aula cedidas e a seus alunos que responderam aos testes. Sem a colaboração de vocês não teria sido possível realizar esta pesquisa. 
Um agradecimento especial ao meu genro e professor de inglês, Plinio, e à minha filha, Bárbara, pela ajuda com o resumo em inglês.

À UNIFAL-MG, agradeço pela colaboração dos diversos setores que de alguma forma possibilitaram a realização deste sonho: a Pró-Reitora de Extensão, Eliane, Deíse, da PróReitoria de Gestão de Pessoas e ao Setor de Transportes, que tantas vezes tornou mais confortável e rápido meu deslocamento para São Paulo.

A todos e a todas vocês, mais uma vez, gratidão, gratidão, gratidão. 


\section{RESUMO}

BALLESTEROS, M.A.C. Y si esta não for uma Oração Condicional? A (não) influência do contexto e da instrução formal na compreensão de um enunciado complexo. Dissertação (Mestrado). Faculdade de Filosofia, Letras e Ciências Humanas, Universidade de São Paulo, 2019.

É recorrente, nos estudos gramaticais do Português Brasileiro e do Espanhol, a identificação da conjunção condicional SE/SI como introdutora de Orações Condicionais. No entanto, frente a alguns enunciados introduzidos pela partícula $E / Y+S E / S I$ como " $¿ Y$ si pintamos una bailarina?" e "¿Y si jugamos a otra cosa?"(Em Batu, de Juan Matías Loiseau - Tute) dita classificação não condiz com a de uma Oração Condicional prototípica. Matte Bon (1995), Escandell Vidal (1999), Montolío (1999), Moura Neves (2000), Fernández Lanza (2008) e Perini, (2010) coincidem quanto à classificação dessa estrutura como pertencente às Orações Condicionais. A partir desta questão, discutem-se dois aspectos neste trabalho: o primeiro tem a ver com a pertinência da classificação dessas orações como "Condicionais não prototípicas" e, o segundo, refere-se à compreensão, por parte dos alunos de Espanhol como Língua Estrangeira, dos efeitos de sentido produzidos em tais enunciados, influenciados (ou não) por diferentes elementos do contexto e pela instrução formal. Tomando como base outros estudos sobre Orações Condicionais (BAGNO, 2011; KOCH, 2011; CASTILHO, 2014) e à luz de Montolío (1999) entende-se que os enunciados em questão apresentam um importante componente pragmático, que vem ao encontro da hipótese referente à possibilidade da influência de diferentes elementos do contexto (PARRET, 1985; IBAÑEZ, 1990; VAN DIJK, 2007, 2012) para a compreensão por parte dos aprendizes brasileiros de espanhol. O corpus desta pesquisa constitui-se de respostas dos sujeitos de pesquisa (alunos de E-LE do Ensino Médio e de Pós-graduação), a partir de duas atividades baseadas em uma tirinha: uma de reformulação das falas dos personagens e outra de elaboração de um relato da narrativa. A partir da análise destas respostas, argumenta-se, partindo das contribuições de Koch (2011) e dos estudos de Portolés (1988), que a partícula E/Y seria um operador argumentativo que aliado à modulação interrogativa do enunciado gera um efeito atenuador de cortesia (BRIZ, 2013). Quanto à influência do contexto, concluímos que este se constitui de componentes verbais e não verbais e estes terão maior ou menor influência na compreensão, conforme a relevância de um ou de outro elemento, para o interlocutor. Nossa análise permite afirmar que, no caso dos enunciados em questão, a instrução formal não teve qualquer influência na compreensão do efeito de sentido.

Palavras-chave: Compreensão, Contexto, Operador argumentativo 


\section{ABSTRACT}

BALLESTEROS, M.A.C. What if this is not a Conditional Sentence? The (non) influence of the context and the formal instruction on the comprehension of a complex statement. MSc Dissertation. Faculdade de Filosofia, Letras e Ciências Humanas, Universidade de São Paulo, 2019.

It is recurrent, in grammatical studies of Brazilian Portuguese and Spanish, the identification of the conditional conjunction SE/SI as introductory of Conditional Sentences. However, against some statements introduced by the particle $E / Y+S E / S I$ as " $¿ Y$ si pintamos una bailarina?”and “ ¿Y si jugamos a otra cosa?” (In Batu, de Juan Matías Loiseau - Tute) this classification doesn't match with the prototypical Conditional Sentence. Matte Bon (1995), Escandell Vidal (1999), Montolío (1999), Moura Neves (2000), Fernández Lanza (2008) e Perini, (2010) agree about this classification of the structure as belonging to Conditional Sentences. From this point of view, two aspects are discussed in this work: the first one has to do with the pertinence of the classification of this sentences as "non-prototypical conditionals" and the second one refers to the comprehension, by students of Spanish as a Foreign Language and the effects of meaning produced on those statements, influenced (or not) by different context elements and by formal instruction. Based on another studies about Conditional Sentences (BAGNO, 2011; KOCH, 2011; CASTILHO, 2014) and considering Montolío (1999) it is understood that the statements referred, presents an important pragmatic component, to the possibility of the influence of different elements of context (PARRET, 1985; IBAÑEZ, 1990; VAN DIJK, 2007, 2012) for a comprehension by Brazilians Spanish learners. The corpus of this research consists of answers of the research subjects (students of Spanish as a Foreign Language in Secondary School and Post-Graduation), based on two activities: a reformulation of the speech of the cartoon characters and an elaboration of a narrative description of the text. Considering the analysis of the answers, with the contributions of Koch (2011) and the studies of Portolés (1988), argues that the E/Y particle would be an argumentative operator that allied with the interrogative modulation of the statement, generating an attenuating courtesy effect $(B R I Z, 2013)$. About the influence of the context, we concluded that it consists of verbal and nonverbal components and these will have a bigger or smaller influence on the comprehension, according to the relevance of one or another element, for the interlocutor. The analyzes allow to affirm that in case of the statements discussed about, the formal instruction did not have any influence on the comprehension in the effect of meaning.

Keywords: Comprehension, Context, Argumentative operator. 


\section{RESUMEN}

BALLESTEROS, M.A.C. ¿Y si esa no es una Oración Condicional? La (no) influencia del contexto y de la enseñanza formal en la comprensión de un enunciado complejo. TFM (Maestría). Faculdade de Filosofia, Letras e Ciências Humanas, Universidade de São Paulo, 2019.

En los estudios gramaticales del Portugués Brasileño y del Español, es recurrente que la conjunción condicional SE/SI esté identificada como introductora de Oraciones Condicionales. Sin embargo, delante de algunos enunciados introducidos por la partícula E/Y + SE/SI como en “¿Y si pintamos una bailarina?” e "¿Y si jugamos a otra cosa?" (Batu, de Tute - Juan Matías Loiseau) dicha clasificación no condice con la de una Oración Condicional prototípica. Matte Bon (1995), Escandell Vidal (1999), Montolío (1999), Moura Neves (2000), Fernández Lanza (2008) y Perini, (2010) coinciden respecto a la clasificación de esa estructura como integrante de las Oraciones Condicionales. Sobre la base de este planteamiento se discuten dos aspectos en este trabajo: el primero tiene que ver con la pertinencia de la clasificación de esas oraciones como "Condicionales no prototípicas" y el segundo se refiere a la comprensión de los efectos de sentido que se producen con tales enunciados, influenciados (o no) por diferentes elementos del contexto y por la enseñanza formal por alumnos de Español como Lengua Extranjera. Con base en otros estudios sobre las Oraciones Condicionales (BAGNO, 2011; KOCH, 2011; CASTILHO, 2014) y en aportes de Montolío (1999) se entiende que los enunciados destacados presentan un importante componente pragmático, lo que corrobora con la hipótesis sobre la posibilidad de la influencia de diferentes elementos del contexto (PARRET, 1985; IBAÑEZ, 1990; VAN DIJK, 2007, 2012) para la comprensión por parte de aprendices de español nativos de Brasil. El corpus de esta investigación se compone de respuestas de alumnos de E-LE de la enseñanza secundaria y de posgrado, en función de dos actividades apoyadas en una historieta: una de reformulación de las hablas de los personajes y otra de producción de un relato del argumento. A partir del análisis de las respuestas, se argumenta, de acuerdo con las contribuciones de Koch (2011) y de los estudios de Portolés (1988), que la partícula $E / Y$ puede ser un operador argumentativo que, juntamente con la modulación interrogativa del enunciado, genera un efecto atenuador de cortesía (BRIZ, 2013). En cuanto a la influencia del contexto, se concluye que este se constituye de componentes verbales y no verbales y que referidos componentes tendrán mayor o menor influjo en la comprensión según la relevancia que tenga uno u otro elemento para el coenunciador. El análisis permite afirmar que, en el caso de los enunciados en cuestión, la enseñanza formal no tuvo ninguna influencia en la comprensión del efecto de sentido.

Palabras clave: Comprensión, Contexto, Operador argumentativo 


\section{SUMÁRIO}

INTRODUÇÃO 12

1 ORIGENS: A ESCOLHA DO TEMA. 12

2 NOVAS QUESTÕES, NOVOS CAMINHOS: EM BUSCA DE RESPOSTAS. 14

2.1 QUE PERGUNTAS BUSCAMOS RESPONDER E POR QUÊ? 15

3 ObjetIVOS DESTE TRABALHO 17

4 A ESTRUTURA DESTE TRABALHO 18

1.2 (DES)CONSTRUINDO OS ENUNCIADOS DOS TESTES

1.2.1 OS ELEMENTOS DOS ENUNCIADOS DOS TESTES

1.2.1.1 Estudos referentes ao Português Brasileiro (PB)

1.2.1.1.1 Sobre a estrutura prototípica das Orações Condicionais

1.2.1.1.2 Sobre a forma interrogativa do enunciado utilizado nos testes

1.2.1.1.3 Sobre as orações interrogativas e a Oração Condicional sem apódose, introduzida pela partícula $E$

1.2.1.1.4 Sobre a Classificação Sintática das Orações Condicionais

1.2.1.2 Estudos referentes ao Espanhol

1.2.1.2.1 Sobre a estrutura prototípica das Orações Condicionais

1.2.1.2.2 Sobre as Orações Condicionais sem apódose, introduzidas pela partícula Y

1.2.1.2.3 Sobre a forma interrogativa

1.2.1.2.4 Sobre a Classificação Sintática das Orações Condicionais

1.2.2 SOBRE COMPREENSÃO, CONTEXTO E RECURSOS ARGUMENTATIVOS

1.2.2.1.1 A Teoria da Compreensão de Parret (1985)

1.2.2.1.2 A Teoria do Contexto Verbal de Ibañez (1990)

1.2.2.1.3 A Teoria do Contexto de van Dijk $(2007,2012)$ 
2.1 INTRODUÇÃO 55

2.2 LOCAL E SUJEITOS DA PESQUISA 55

2.3 MetOdologia de PESQUISA 56

2.3.1 A IDENTIFICAÇÃO DOS SUJEITOS DE PESQUISA 56

2.3.2A COMPOSIÇÃO DO CORPUS 56

2.4 UMA ANÁLISE POSSÍVEL 59

2.4.1 SOBRE A TIRINHA 1 59

2.4.1.1 Um breve relato 60

2.4.1.2 Componentes do contexto 60

2.4.1.3 Nossa análise 60

2.4.2 SOBRE A TIRINHA 2 63

2.4.2.1 Um breve relato 63

2.4.2.2 Componentes do contexto 63

2.4.2.3 Nossa análise 64

2.5 A TÍTULO DE SÍNTESE 65

3.2.1.1 Ocorrências relacionadas a elementos icônicos na Tirinha 1 
3.2.1.2.3 Efeito de sentido de DÚVIDA

3.2.1.2.4 Efeitos de sentido não explicitados

3.2.1.2.5 Cruzamento entre as ocorrências de elementos icônicos e o efeito de sentido explicitado pelos sujeitos informantes na Tirinha 1

3.2.1.3 Ocorrências relacionadas a elementos linguísticos na Tirinha 1 79

3.2.1.4 Resultados parciais referentes à Tirinha 1 79

3.2.2 ANÁLISE DOS DADOS DO GRUPO 2 - TIRINHA 2 80

3.2.2.1 Ocorrências relacionadas a elementos icônicos na Tirinha 2 82

3.2.2.1.1 Batu visto como uma menina 82

3.2.2.1.2“Apagamento" de Tútum 83

3.2.2.1.3 $O$ desenho de uma árvore? 83

3.2.2.1.4 Identificação dos personagens 84

3.2.2.2 Ocorrências relacionadas a elementos socioculturais na Tirinha 2 84

3.2.2.2.1 Efeito de sentido de SUGESTÃO 84

3.2.2.2.2 Efeito de sentido de DECISÃO 85

3.2.2.2.3 Efeito de sentido de ACORDO 86

3.2.2.2.4 Efeitos de sentidos não explicitados 86

3.2.2.2.5 Cruzamento entre as ocorrências de elementos icônicos e o efeito de sentido explicitado pelos sujeitos informantes na Tirinha 2

3.2.2.3 Ocorrências relacionadas a elementos linguísticos da Tirinha 2 88

3.2.2.3.1 Questões modo-temporais da Tirinha 2 88

3.2.2.3.2 Tútum também fez uma sugestão 89

3.2.2.4 Algumas interpretações interessantes 90

3.2.2.4.1 Humor ou comicidade 90

3.2.2.4.2 O desconforto de Boris 90

3.2.2.5 Resultados parciais referentes à Tirinha 2 
4.2.1.3 À luz da semântica argumentativa

4.2.1.4 Tomando os enunciados em análise

4.2.2 QUAL EFEITO DE SENTIDO ATRIBUÍMOS À MODULAÇÃO INTERROGATIVA?

4.2.2.1 Quanto à modulação interrogativa

4.2.2.2 Y si isto for uma forma de cortesia? 95

4.3 OBJETIVOS E PERGUNTAS DE PESQUISA 96

4.3.1 A INFLUÊNCIA DE ELEMENTOS DISCURSIVO-PRAGMÁTICOS NO EIXO PRODUÇÃO-COMPREENSÃO 97

4.3.2 OS COMPONENTES DO CONTEXTO E SUA INFLUÊNCIA NA COMPREENSÃO 97

4.3.3 O QUE OS DADOS REVELARAM SOBRE A COMPREENSÃO 98

4.3.4 QUANTO À INSTRUÇÃO FORMAL 99

4.4 À GUISA DE CONCLUSÃO 99

BIBLIOGRAFIA 101

REFERÊNCIAS BIBLIOGRÁFICAS 101

BIBLIOGRAFIA DE APOIO 104

APÊNDICE ATIVIDADES - QUADROS 106

ATIVIDADES PARA COMPOSIÇÃO DO CORPUS 106

ATIVIDADES DA TIRINHA 1 106

ATIVIDADES DA TIRINHA 2 107

QUADROS 108

QuAdRo 1: TIPOS de CONTEXTo em RELAÇÃo A TIPOS de ORIENTAÇÃo PRAGMÁtICA 108

QUADRO 2: ESQUEMA APRESENTADO POR IBAÑEZ 108

QUADRO 3: COMPONENTES DO CONTEXTO 109

QUADRO 4: SÍNTESE DE NOSSO ENTENDIMENTO SOBRE "Y SI" 109

QUADRO 5: COMPILAÇÃO DE RESPOSTAS PARA A TIRINHA 1 110

QUADRO 6: CONSTRUÇÃO DE EFEITO DE SENTIDO VERSUS ELEMENTO ICÔNICO- TIRINHA 1 114

QUADRO 7: COMPILAÇÃO DE RESPOSTAS PARA A TIRINHA 2 115

QUADRO 8: CONSTRUÇÃO DE EFEITO DE SENTIDO VERSUS ELEMENTO ICÔNICO- TIRINHA 2 119 ANEXO TIRINHAS 120 


\section{INTRODUÇÃO}

"O conhecimento avança à medida que o seu objeto se amplia, ampliação que, como a da árvore, procede pela diferenciação e pelo alastramento das raízes em busca de novas e mais variadas interfaces."

(Boaventura de Souza Santos, 2003, p.66)

\section{Origens: A escolha do tema.}

Nossa pesquisa se debruça sobre a influência (ou não) do contexto para a compreensão, nos termos de Parret (1985), de um enunciado aparentemente simples, por alunos de Espanhol como Língua Estrangeira (doravante E-LE), falantes nativos de português brasileiro (doravante $\mathrm{PB})$.

Este trabalho é um desdobramento de uma pesquisa de Iniciação Científica (IC), realizada durante nossa Graduação em Letras-Espanhol ${ }^{1}$, motivada pela observação de dificuldades que alguns colegas de graduação apresentaram, durante o estudo das Orações Condicionais, em Espanhol, com relação ao efeito de sentido que determinadas combinações modo-temporais proporcionavam, especificamente quanto à gradação da possibilidade de realização ou não da ação ${ }^{2}$.

Naquela, o objeto de estudo tomava as Orações Condicionais, em sua estrutura prototípica [SE $p$ (oração subordinada), q (oração principal)] para uma comparação entre o Espanhol e o $\mathrm{PB}$, com relação a combinações modo-temporais que imprimem ao enunciado diferentes aspectos pragmático-discursivos. O objetivo daquele estudo era verificar se alunos de um curso de Letras-Espanhol, falantes nativos de PB e futuros professores de E-LE, percebiam ${ }^{3}$ esses aspectos e como essa percepção afetava a compreensão dos enunciados em questão.

Dos resultados obtidos, destacamos dois como mais relevantes. O primeiro se refere às combinações modo-temporais enquanto recurso linguístico para construção de efeito de sentido. As análises dos testes comprovaram que estas constituem um recurso linguístico muito mais utilizado no Espanhol que no $\mathrm{PB}$, embora o número de combinações elencadas por

\footnotetext{
${ }^{1}$ Sob a orientação da Profa Dra. Kátia Aparecida da Silva Oliveira, na Universidade Federal de Alfenas - UNIFALMG.

${ }^{2}$ Cabe esclarecer que, além de já ter concluído, em 2004, uma Licenciatura em Letras Português-Inglês, por ser filha de espanhóis, aprendi a falar em Espanhol antes de ser alfabetizada no Português. Esta situação me permitiu ter um olhar diferenciado para as questões do E-LE, na turma do curso de Letras-Espanhol.

3 Termos relacionados ao "perceber" foram empregados no trabalho de IC sem grande atenção ao valor semântico que este vocábulo carrega. Durante o desenvolvimento desta proposta, no entanto, uma maior atenção à distinção entre "compreensão" e "percepção" demandou um maior aprofundamento conceitual e teórico, do qual trataremos no Capítulo 1, dedicado à fundamentação teórica e conceitual.
} 
Moura Neves (2000), para o PB, seja consideravelmente maior que o relatado por Montolío (1999), para o Espanhol, conforme verificado em Ballesteros (2016):

Observou-se que somente 12 combinações modo-temporais encontram equivalência entre as quarenta e seis apresentadas para o Português e as vinte apresentadas para o Espanhol, além de diferenças na classificação quanto à graduação de possibilidade de realização das ações apresentadas nas orações principais. Algumas dessas "lacunas" têm explicação gramatical, como é o caso das ocorrências que utilizam o futuro do Subjuntivo, em Português, devido a este tempo verbal estar em desuso no Espanhol, substituído pelo presente de Subjuntivo e, em alguns casos, ainda que não amplamente documentados, pelo pretérito imperfecto do Subjuntivo. Por outro lado, o falante de Português tem a opção do uso do infinitivo pessoal ou flexionado, inexistente no Espanhol. Segundo Maurer Júnior (1968), citado por Sandes (2001, p.38), o infinitivo flexionado do português "é uma notável peculiaridade do português entre as línguas da família românica". (p.7)

Entendemos que, por ter um menor número de opções combinatórias, com relação ao PB, o Espanhol explora com maior frequência esses recursos para a codificação do estatuto realizável/irrealizável de uma condição. Além disso, o falante de PB conta com o infinitivo flexionado como recurso para uma substituição de algumas dessas formas de combinação gerando um "vazio de equivalência" (BALLESTEROS, 2016, p.7). Acreditamos ser este "vazio" um fator importante para a dificuldade de compreensão e de produção de falantes do PB em processo de aprendizagem do E-LE e que constitui uma possível explicação para outro resultado apontado por nossa pesquisa, relatado em seguida.

Em uma dada atividade, os sujeitos deveriam explicitar o sentido e avaliar a probabilidade de realização de uma determinada ação, apresentada em Espanhol com uma versão correspondente em PB. Assim, criou-se uma situação de confronto entre diferentes combinações modo-temporais para cada língua, em uma mesma situação. Diante do par de enunciados:

(1) Si hubiera sido dedicado, habría ganado el premio

(2) Se eu fosse aplicado, obteria o prêmio

Todos os sujeitos declararam que ambas as situações tinham o mesmo sentido - frustração. No entanto, a metade considerou haver alguma possibilidade de realização, desconsiderando a combinação modo-temporal que marca a ação como concluída [pretérito do Subjuntivo], bem como o sentido de frustração que denota o sentimento negativo pelo insucesso ou impedimento de realizar algo da maneira esperada, ou seja, que já aconteceu.

As atividades apresentadas aos sujeitos de pesquisa da IC foram elaboradas com base em Bruno (2006) e as análises do corpus gerado se orientaram pelo "modelo interpretativo" proposto pela mesma autora, considerando o cruzamento de informações provenientes das 
respostas às questões aplicadas, incluindo-se as reformulações ${ }^{4}$, o rascunho mental ${ }^{5}$, conhecimentos prévios e subtexto ${ }^{6}$.

Foi possível identificar uma assimetria no "eixo produção-compreensão"7 (BRUNO, 2006), pois, os sujeitos compreenderam o sentido, mas não perceberam o efeito causado por elementos pragmáticos relacionados às construções modo-temporais. Ficou evidente que, para os sujeitos, falantes nativos de $\mathrm{PB}$, os aspectos pragmáticos e os efeitos de sentido, decorrentes das combinações modo-temporais presentes nas construções condicionais em Espanhol apresentadas, são, em algumas situações, quase imperceptíveis.

Além disso, independentemente do tempo de estudos de E-LE, foi possível evidenciar que o efeito de sentido das Orações Condicionais utilizadas foi avaliado com base no conhecimento linguístico e pragmático que o sujeito tem do PB.

Considerando que, no trabalho desenvolvido na IC, somente os enunciados foram apresentados aos sujeitos, o resultado obtido nos instigou a um desdobramento daquela pesquisa. Desta vez, durante o processamento da informação, "momento em que os aprendizes manipulam os dados da língua estrangeira" (BRUNO, 2006, p. 17), foram observadas duas questões: a influência dos diferentes elementos do contexto ${ }^{8}$ e da instrução formal para a compreensão.

Também identificamos a necessidade de repensar a forma de contribuição dos sujeitos da pesquisa, passando a solicitar-lhes produzir enunciados, além de apenas explicitar sua compreensão, como havia sido feito na IC.

\section{Novas questões, novos caminhos: em busca de respostas.}

A fim de testar estas alterações e ampliar o formato da pesquisa, elaboramos um teste-piloto utilizando tirinhas, por pertencerem a um gênero que possibilita apresentar enunciados com outros elementos contextuais e de forma sintética.

\footnotetext{
${ }^{4}$ Adotamos reformulação como "a transformação de uma unidade discursiva de tamanho variável (da palavra ao texto) numa outra que seja, de uma maneira ou de outra, considerada semanticamente "equivalente»" (MAINGUENEAU, 1997, p.86)

${ }^{5}$ Processo referido em Vygotsky (2008) no qual "A passagem da linguagem interior para a exterior é uma complexa transformação dinâmica - uma transformação da linguagem predicativa e idiomática em uma linguagem sintaticamente decomposta e compreensível para todos". (p.474)

${ }^{6} \mathrm{O}$ conceito de subtexto, elaborado por Vygotsky (2008), refere-se a um pensamento oculto por trás do que foi ou não dito: um pormenor gramatical pode, às vezes, modificar todo o teor do que se diz. (p.160)

${ }^{7}$ Termo cunhado por Bruno (2006) para o "processamento e o processo em direção à língua estrangeira a partir da gênese dialética entre produção e compreensão". (p.152)

${ }^{8} \mathrm{~A}$ partir do avanço da pesquisa, aprofundamos nosso estudo sobre o contexto e seus componentes. Os resultados deste serão apresentados no Capítulo 1.
} 
Nossa escolha inicial, para a elaboração dos testes, foi por buscar tirinhas de Mafalda personagem de Quino, ou Gaturro - personagem de Nik, ${ }^{9}$ considerando serem personagens conhecidos do público-alvo de nossos testes, fator que contribui com a compreensão.

Diante de certa dificuldade em localizar, nessas historietas, o tipo e a estrutura de enunciados que buscávamos, encontramos em Batu ${ }^{10}$, personagem de Tute, uma forma "simples" de um enunciado "aparentemente condicional".

Entenda-se por forma "simples" uma referência à definição apresentada, de modo quase unânime, por gramáticos e linguistas consultados durante a pesquisa de IC (Matte Bon, 1995; Montolío, 1999; Moura Neves, 2000; Fernández Lanza, 2008; Perini, 2010; Castilho, 2014), para as Orações Condicionais, seja no Português, seja no Espanhol, como sendo basicamente, um enunciado complexo composto por dois enunciados simples que estabelecem uma relação entre uma hipótese ou condição e sua realização ou não, cuja forma mais comum será: Se S1, então S2, na qual S1 denomina-se antecedente, prótase ou hipótese e S2 consequente, apódose ou tese.

A expressão "aparentemente condicional" reflete um questionamento particular nosso que já havia surgido durante as análises na IC, mas, que devido ao recorte da pesquisa, não foi abordado naquela oportunidade. Trata-se de alguns exemplos de Orações Condicionais, encontrados nas gramáticas consultadas naquela ocasião, que apresentavam a estruturação sintática prototípica Se S1, então S2, mas não traziam em si a principal característica atribuída a esta classe de orações: a relação condicional entre um antecedente e um consequente, como se observa no exemplo:

(3) Mira, si eso es música, yo soy Beethoven ${ }^{11}$

Si eso es música introduz um não fato: yo soy Beethoven, que não constitui uma possibilidade. Por isso, não se trata de uma condição, mas sim de uma maneira modalizada de dizer que "eso" não é música.

\subsection{Que perguntas buscamos responder e por quê?}

Os enunciados encontrados em Batu apresentaram uma estrutura ainda mais instigante de análise e de pesquisa, pois são introduzidos pela partícula " $Y$ ", correspondente ao " $E$ ", em Português, em modulação interrogativa e sem o consequente, apódose ou tese.

\section{(4) ¿Y si jugamos a otra cosa?}

\footnotetext{
${ }^{9}$ Quino é um cartunista argentino, criador de Mafalda, uma menina inteligente que apresenta questionamentos sobre a vida e a sociedade, em sua maioria, desconcertantes. Nik, apelido de Cristian Dzwonik, é também um cartunista argentino, quarenta anos mais jovem que Quino. Mais conhecido pela criação do personagem Gaturro, um gato cheio de imaginação e apaixonado por Ágatha, uma gata que não corresponde ao seu amor.

${ }^{10}$ Batu é um garoto muito criativo, de cabelos ruivos, que sempre está acompanhado de seu cãozinho azul Tútum e de seu amigo Boris. O autor é o escritor argentino Tute (Juan Matías Loiseau).

${ }^{11}$ Exemplo encontrado em Montolío (1999, p.3672).
} 


\section{(5) ¿Y si pintamos una bailarina?}

Assim, as questões que nos moviam:

a) Para além das questões sistêmico-formais da língua espanhola, há influência de elementos discursivo-pragmáticos no eixo produção-compreensão;

b) O que está influenciando na compreensão? De que se compõe o contexto que ajuda ou atrapalha na compreensão?;

c) De que forma o contexto e a instrução formal podem (ou não) influenciar na compreensão deste tipo de enunciado?

Se ampliaram e estas passaram a compor nossas perguntas de pesquisa:

d) Este tipo de oração deveria ser classificado como Condicional, de fato, como a classificariam Montolío (1999) e Moura Neves (2000) ou seria melhor considerá-lo como um período hipotético; isto é, a partir de outra classificação?

e) A forma interrogativa utilizada constitui uma maneira cortês ou atenuadora de se posicionar frente ao seu interlocutor, isto é, uma hipótese ou possibilidade válida?

f) Esta locução conjuntiva " $Y$ si" seria um operador argumentativo?

g) Como consequência da instrução formal sobre as Orações Condicionais, com foco na metalinguagem, o que irá pesar mais na compreensão do aprendiz, a formalização dessas formas, o contexto, ambos ou, ainda, nenhum deles, já que, segundo analisamos anteriormente, os enunciados dos testes não se tratam de Orações Condicionais?

Como exemplo de uma possível influência do processo de ensino-aprendizagem, ao qual os alunos costumam ser submetidos, apresentamos uma observação de Bruno (2006). Em testes realizados, para a elaboração do corpus de sua pesquisa, a autora destaca que alguns alunos justificaram que a compreensão havia se dado com base nas últimas aulas que haviam tido sobre determinado tema, sendo que este não tinha nenhuma relação com a questão da impessoalidade, a qual estava sendo analisada naquela pesquisa.

O fato de o aluno buscar amparo no conteúdo das últimas aulas permite-nos supor que ele acreditava tratar-se de um exercício para a prática de temas abordados recentemente. Encontramos em Possenti (2006) uma possível explicação para este fato. Dentre as inúmeras críticas que o autor tece com relação à condução dada ao ensino da língua na Escola, destacase a prática pedagógica voltada para exercícios que nada têm a ver com a prática da linguagem (construir frases com palavras dispersas, separar sílabas, dar diminutivos...). Possenti (2006, p. 47) enuncia uma espécie de lei: "não se aprende por exercícios, mas por práticas significativas".

O aluno do qual não se exige reflexão sobre a língua e a linguagem, apresenta grande dificuldade para desenvolver sua autonomia didática, qual seja a capacidade de aprender a 
aprender e se desenvolver por conta própria. Entendemos que Fernández (1987, p. 11) citada em Bruno (2004, p.20), expressa nosso pensamento de forma bastante precisa:

As atividades e a reflexão sobre o sistema da língua - gramática - se encaixam em um objetivo mais amplo que é o de pretender dar ao aluno o domínio de todos os recursos da língua para se comunicar na sua dupla vertente de compreensão e produção. (tradução e grifo da autora).

A partir dessas reflexões e ocorrências, nos deparamos com a necessidade de um aporte teórico e uma ampliação substancial de nossa pesquisa, que detalharemos no Capítulo 1, no qual apresentamos a Fundamentação Teórica.

\section{Objetivos deste trabalho}

Esta Dissertação tem como objetivo apresentar nossas conclusões sobre a influência ou não de diferentes elementos do contexto e da instrução formal na compreensão de enunciados, que segundo alguns estudiosos, são considerados como "condicionais" (MATTE BON, 1995; MONTOLÍO, 1999; MOURA NEVES, 2000; FERNÁNDEZ LANZA, 2008; PERINI, 2010; CASTILHO, 2014), "pseudocondicionais" (JULIÁN MARISCAL, 2007; RAE, 2010), ou ainda "condicionais sem apódose" (ESCANDELL VIDAL, 1999), os quais serão manipulados por alunos de E-LE falantes nativos do PB.

Ao aprofundar os estudos iniciados na IC, referente às Orações Condicionais, do ponto de vista de sua estrutura e efeitos de sentido, discutimos a pertinência da classificação das Orações Condicionais não prototípicas ${ }^{12}$, utilizadas nos testes desta pesquisa.

A forma prototípica das Orações Condicionais Se S1, então S2, apresentada nas gramáticas como uma composição de duas orações simples, conforme apontamos anteriormente, não contempla alguns elementos que conferem à estrutura dessas orações um alto grau de complexidade. Montolío (1999) entende tratar-se de um "mecanismo cognitivo fundamental", uma das principais formas de o falante expressar sua capacidade de imaginar situações diferentes das situações reais e, por isso, exigir uma análise que combina elementos gramaticais, semânticos e pragmáticos, apresentando múltiplas possibilidades de construção de sentidos.

Consideremos que a relação $S 1 \Lambda S 2$ se dá mediante um ato linguístico, para o qual contribuem sujeitos de um discurso que compartilham informações, conhecimentos e conceitos que envolvem aspectos socioculturais, além de discursivo-pragmáticos. Mais para além, especificamente nesta construção, a relação que se estabelece depende, também, de um desenvolvimento lógico, pois o grau de possibilidade de realização da hipótese ou condição

\footnotetext{
${ }^{12}$ Adotamos a terminologia "não prototípica", visto não termos encontrado, em nossos estudos, uma classificação gramatical específica para a estrutura dos enunciados utilizados em nossos testes: "Y si S1?" (E se S1? - em PB).
} 
depende do atendimento de premissas ou condições para um resultado válido/verdadeiro ou não válido/falso.

Como objeto desta pesquisa, escolhemos uma produção não prototípica desse tipo de oração, que apresenta três novos elementos:

a) Tomando por base que a capacidade do falante de imaginar situações diferentes daquelas que são reais se materializa linguisticamente na hipótese (prótase) ou seja, na oração principal da estrutura condicional, propomos analisar um enunciado que não apresenta uma oração subordinada, ou seja, não traz a tese (apódose);

b) é introduzida pela partícula $Y$ (correspondente à $E$, em português), antecedendo a conjunção prototípica SI (correspondente ao SE, em português); e

c) apresenta-se na forma interrogativa.

Considerando a presença de todos esses elementos - uma Oração Condicional sem apódose, introduzida pela partícula $Y$, na forma interrogativa - e os efeitos de sentido possíveis esta pesquisa teve como objetivo central evidenciar de que forma os diferentes elementos do contexto e a instrução formal têm influência na compreensão deste tipo de enunciado por alunos de E-LE, falantes nativos de PB.

Avaliar a influência da instrução formal para a compreensão encontra inspiração em um dos resultados obtidos por Bruno (2006) para o teste de compreensão, cujo enunciado "Después de todo, la pintura se ha de hacer tal como uno es" ( $p .80)$ foi apresentado como mostramos abaixo.

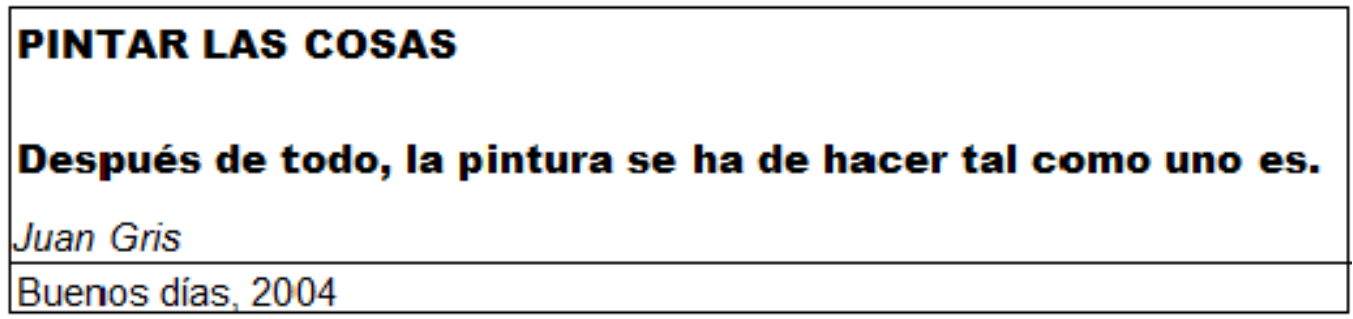

Segundo a pesquisadora, este foi o teste que obteve melhores índices de compreensão apesar de ser aquele que oferecia menor informação pragmática. O fato de não haver uma contextualização, indica que bastou aos sujeitos a informação trazida pelo co-texto (a estrutura macro-gramatical), nos termos de Parret (1985). Além disso, esse índice de compreensão se deu independentemente do tempo de instrução formal dos informantes.

\section{A estrutura deste trabalho}

A fim de apresentar as respostas para nossas questões, organizamos este trabalho da seguinte forma: no Capítulo 1, apresentamos estudos referentes a elementos componentes dos 
enunciados que utilizamos nos testes e discutimos sobre as possíveis relações que se estabelecem entre estes elementos, a partir dos conceitos de "compreensão" e "contexto", apresentados por Parret (1984, 1985), Ibañez (1990) e van Dijk $(2007,2012)$ e à luz de questões relacionadas a recursos argumentativos, trazidas por Portolés (1988) e Koch (2011), com base nos quais delineamos nossas análises. Também trazemos uma reflexão relativa ao tratamento de estruturas que, como a que adotamos em nossos testes, encontram-se em lacunas pouco exploradas nas gramáticas, no âmbito da instrução formal.

O segundo capítulo, apresenta uma descrição do local e a caracterização dos sujeitos de pesquisa, bem como a metodologia que utilizamos para a composição do corpus e possibilidades de análise baseadas nos nossos estudos.

O capítulo 3 traz uma descrição dos dados obtidos a partir das respostas dos informantes e as análises destes dados, com base nas quais chegamos aos resultados de nossa pesquisa. Nossas conclusões e considerações finais encontram-se explicitadas no quarto e último capítulo. 


\section{CAPÍTULO 1 Fundamentos teóricos}

"A teoria, qualquer que seja ela e do que quer que trate, deve explicar o que torna possível a produção da própria teoria e, se ela não pode explicar, deve saber que o problema permanece."

(Edgar Morin, 1998, p.185-186)

\subsection{Introdução}

Neste capítulo apresentamos os conceitos iniciais, à luz dos quais elaboramos os testes e baseamos nossa hipótese inicial, quanto à influência dos diferentes elementos do contexto para a compreensão de um enunciado.

Considerando que a pesquisa concluída na IC (BALLESTEROS, 2016) evidenciou que, para os sujeitos, falantes nativos de $\mathrm{PB}$, os aspectos pragmáticos e os efeitos de sentido, decorrentes das combinações modo-temporais presentes nas construções condicionais apresentadas em Espanhol, eram, em algumas situações, quase imperceptíveis e que, os testes foram somente baseados em enunciados, acreditávamos que outros elementos teriam sim, grande influência sobre a compreensão.

O que não sabíamos, naquele momento, era a complexidade envolvida na composição do contexto. Não tínhamos a dimensão da importância e do papel do elemento verbal em sua composição. Nossa noção de contexto se aproximava dos exemplos e usos citados por van Dijk (2012). Segundo o autor, em geral, "os usos de 'context(o)' que se fazem no dia a dia implicam que algo (um evento ou ação) está relacionado a uma dada situação, condições, circunstâncias ou pano de fundo." (p.33). Adquirir consciência desta complexidade exigiu-nos explorar mais profundamente este conceito.

Além disso, independentemente do tempo de estudos de E-LE dos sujeitos, foi possível evidenciar que o efeito de sentido das Orações Condicionais utilizadas foi avaliado com base no conhecimento linguístico e pragmático que o sujeito tem do PB.

\section{2 (Des)Construindo os enunciados dos testes}

Os enunciados que utilizamos em nossos testes (" ¿Y si jugamos a otra cosa?" e " ¿Y si pintamos una bailarina?") pertencem às tirinhas que apresentamos a seguir: 


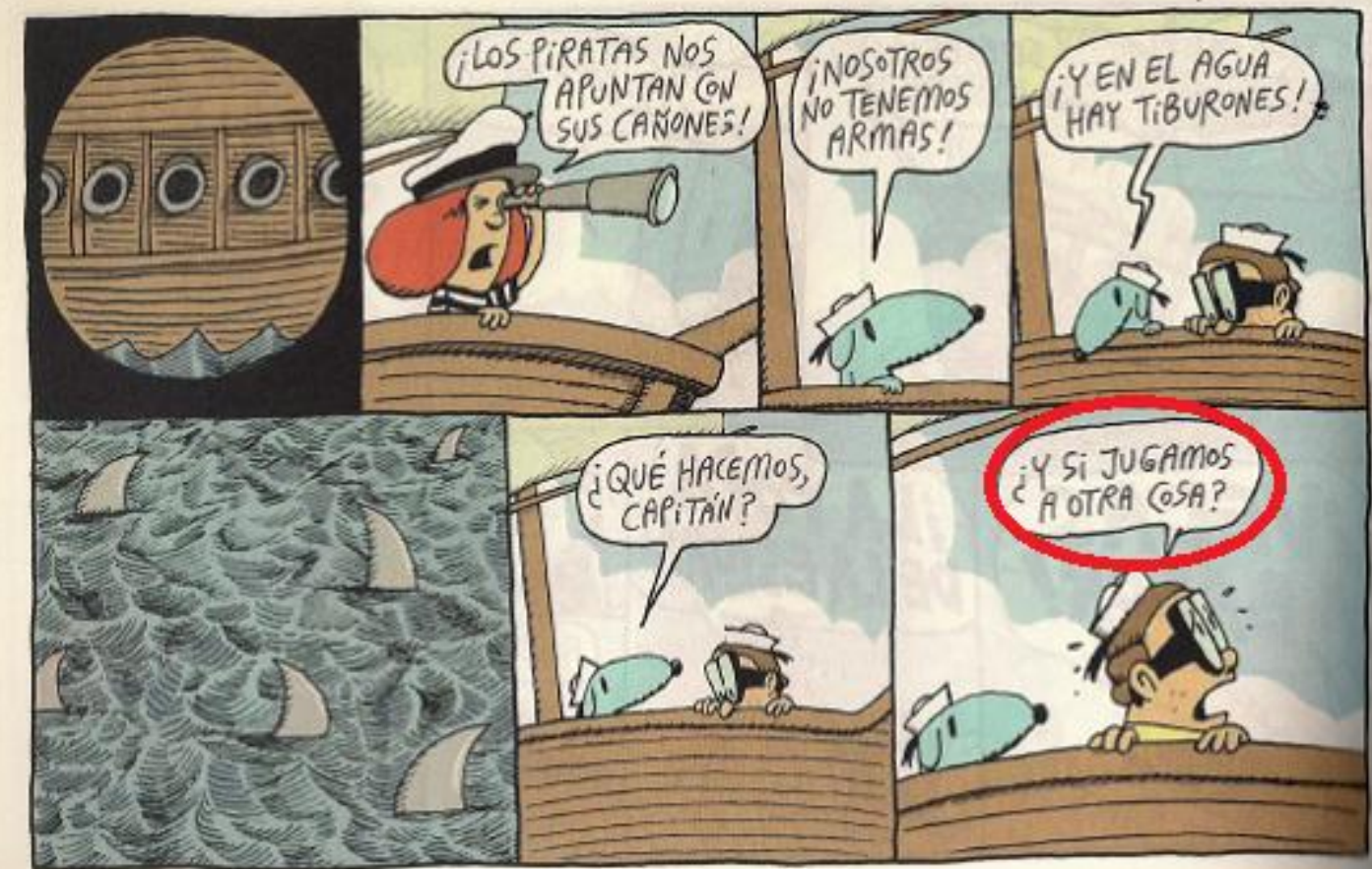

TUTE. Batu. Buenos Aires: Sudamericana, 2009

Tirinha 1

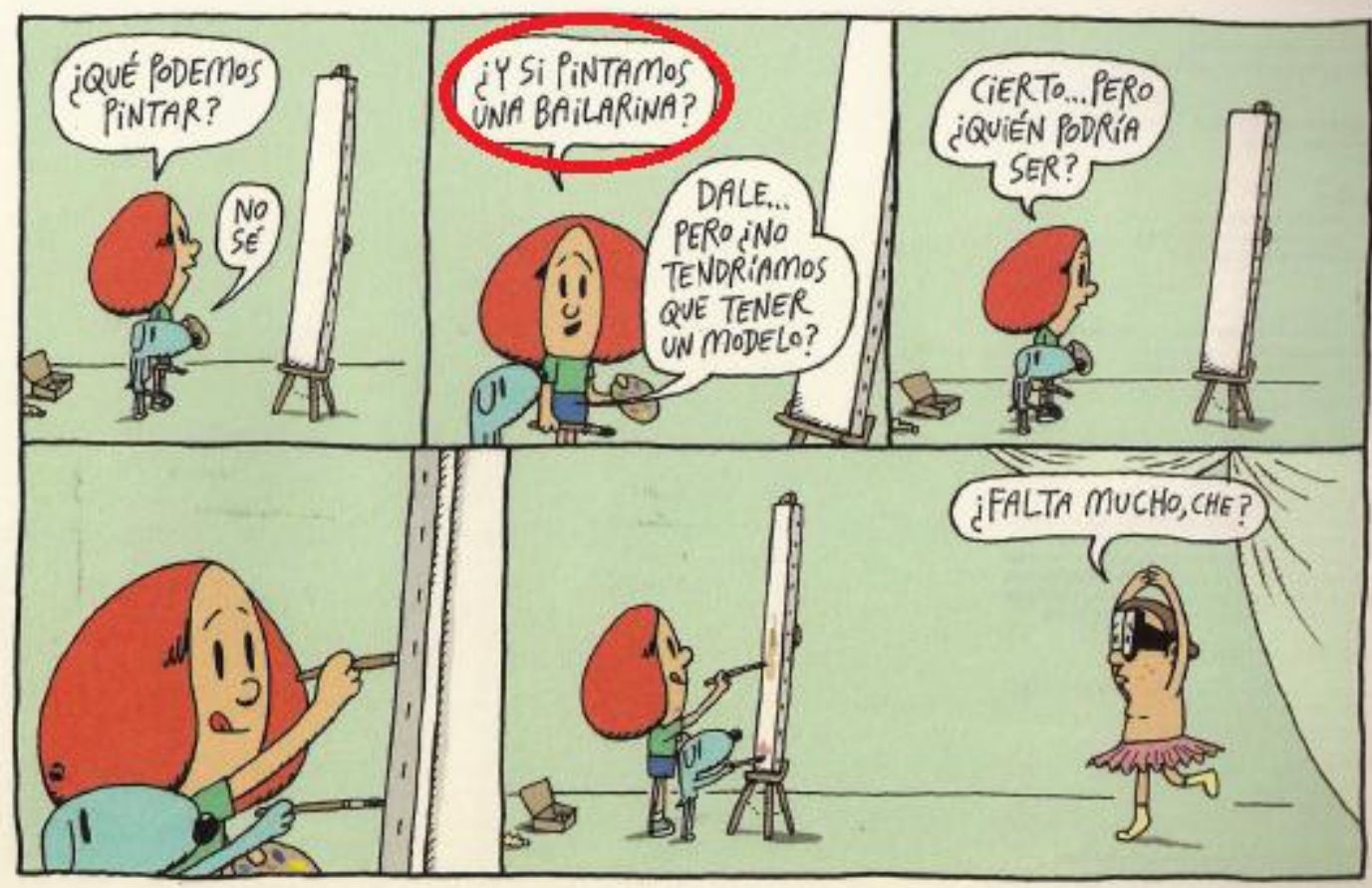

TUTE. Batu. Buenos Aires: Sudamericana, 2009

Tirinha 2

Estas falas dos personagens das tirinhas, num primeiro momento, poderiam se apresentar sob duas possibilidades de classificação gramatical, como uma estrutura: 
a) Condicional não prototípica, introduzida pela partícula " $Y$ ", na forma interrogativa e sem o consequente ou apódose. Moura Neves (2000, p. 832) classifica a forma "se $p, q$ " como a "indicação mais tradicional e comum que se faz para as construções condicionais", em que se estabelece uma relação entre o conteúdo da condicionante (prótase) e a condicionada (apódose). Por exemplo: "Se tudo está desse jeito, eu não posso confiar". Montolío (1999, p. 3647) adota o termo "esquema condicional prototípico" ao tratar das 'construcciones condicionales' introduzidas pelo conector "si".

b) Pseudocondicional. Julián Mariscal (2007, p. 572) adota a terminologia pseudocondicionais para orações que sejam compostas por dois enunciados, um deles introduzido pela partícula "SI", e que não estabeleçam entre si uma relação de condicionalidade (hipotética ou não) ou de causa-efeito. Por exemplo: "Si tienes sed, hay cervezas en la nevera". Diferentemente, a Nova Gramática da RAE (2010, p. 909) define como pseudocondicionais orações que, iniciadas por uma conjunção "SI", sem apresentar uma ideia de hipótese, são utilizadas como recurso retórico para reforçar a verdade ou a falsidade de um ou dos dois componentes da oração, como no exemplo: "Si tú eres Biancio en el pedir, yo soy Alexandro en el dar".

Em ambas definições, o termo pseudocondicional não atende, especificamente, à estrutura dos enunciados utilizados em nossos testes. Tampouco trata-se de uma forma prototípica de Oração Condicional, considerando as definições normalmente encontradas.

Pelo exposto e com base nos principais objetivos desta pesquisa, apresentaremos nesta seção, organizada em três partes, o arcabouço teórico à luz do qual desenvolvemos nossas análises.

A primeira parte apresenta estudos referentes a elementos componentes dos enunciados que utilizamos nos testes, quais sejam: Orações Condicionais, prototípicas e sem o consequente ou apódose, e orações interrogativas; as conjunções " $Y / E$ " e "SI/SE" e aspectos sintáticos de Coordenação/Subordinação. A segunda parte discute sobre a relação ou relações possíveis que se estabelecem entre estes elementos, presentes nos enunciados em questão, com base nos conceitos de "compreensão", "contexto"(PARRET, 1984, 1985; IBAÑEZ, 1990; VAN DIJK, 2007, 2012) e de recursos argumentativos (PORTOLÉS, 1988; KOCH, 2011). Na terceira parte, à luz do Pensamento Complexo (MORIN, 2003, 2006), trazemos uma reflexão relativa ao tratamento de estruturas que, como a que adotamos em nossos testes, encontram-se em lacunas pouco exploradas nas gramáticas, no âmbito da instrução formal.

\subsubsection{Os elementos dos enunciados dos testes}

Visto que para este estudo optamos por utilizar em nossos testes uma forma não prototípica de Oração Condicional, em Espanhol, os estudos referentes aos elementos estruturais e linguísticos presentes nos enunciados que propomos encontram-se separados em duas subseções: estudos referentes ao Português brasileiro e estudos referentes ao Espanhol. 
Nestas, apresentamos definições e classificações sintáticas para Orações Condicionais prototípicas, pois este conhecimento constitui a base para a discussão que propomos. Também a introdução pela partícula "Y/E" requer uma análise a parte, bem como a forma interrogativa e, por essa razão, apresentamos alguns trabalhos referentes às orações interrogativas e os efeitos de sentido que elas trazem.

\subsubsection{Estudos referentes ao Português Brasileiro (PB)}

\subsection{Sobre a estrutura prototípica das Orações Condicionais}

Para o estudo da estrutura prototípica das Orações Condicionais do PB, destacamos os trabalhos de Moura Neves (2000), Perini (2010) e Castilho (2014).

Moura Neves (2000) se apoia em Haimann (1978) quando afirma não existir uma definição satisfatória para as construções condicionais. Segundo os autores, normalmente, os estudos se atêm à construção se S1, S2, menosprezando a complexidade dessa estrutura. A maioria dos estudos citados por Moura Neves (2000) e Haimann (1978) organiza as construções condicionais da seguinte forma: denomina-se prótase $p$ a oração subordinada e apódose $q$, a oração principal. Considerando a relação que se estabelece entre $p$ e $q$, realiza-se um período hipotético, visto que a condição para a realização $\rightarrow$ consequência/resultado da resolução da condição enunciada. Dessa forma, configuram-se três possibilidades, muito próximas às classificações encontradas em outros autores: a verdade de $p$ implica a realização de $q$ - real; a falsidade de $p$ implica a não-realização de $q$ - irreal e a potencialidade de $p$ implica eventualidade de $q$ - eventual.

No entanto, com relação ao subtipo real, Moura Neves (2000) questiona essa denominação, visto que "não se pode falar em realidade, em referência ao que aparece num enunciado, já que a realidade não se confunde com a linguagem: real ou não-real" (p. 836). A autora defende ser mais adequado considerar que a proposição afirma não a realidade de um estado de coisas, mas sim a factualidade do que é dito, daí, adotar a terminologia real/factual. Da mesma forma, para o subtipo irreais, Moura Neves adota irreal/contrafactual.

Em Perini (2010), encontramos uma abordagem focada no conectivo e não nas orações - o Modo Governado. Segundo o autor, o conectivo que introduz uma oração subordinada finita pode governar o modo dessa oração. Por exemplo ${ }^{13}$ :

(6) A gente vai fechar a porta, já que o cachorro entrou.

(7) Se ela quisesse, eu bem que casava com ela.

O modo da oração subordinada será escolhido de acordo com o conectivo utilizado. 0 conectivo já que rege Indicativo. O conectivo se, em sentido condicional, rege Subjuntivo.

\footnotetext{
${ }^{13}$ Exemplos retirados de Perini (2010, p.201)
} 
No caso do conectivo SE, Perini (2010) afirma tratar-se de uma conjunção que é "peculiar e merece um estudo separado" (p.204), por apresentar quatro usos possíveis, de acordo com as correlações modo-temporais que se estabelecem: a) condicional; b) contrafactual; c) factivo e d) nominalizador.

No escopo desta pesquisa, interessam-nos as três primeiras correlações modo-temporais citadas, por expressarem condição ou hipótese: as referentes ao SE condicional, que pode coocorrer com o modo Indicativo ou com o [Imperfeito ou o Futuro do Subjuntivo], para expressar uma condição; o SE contrafactual que utilizando o [Imperfeito do Subjuntivo] denota algo que não é verdadeiro ou provável e o SE factivo que exprime um fato, sempre com o verbo no Indicativo. O SE nominalizador introduz uma interrogativa indireta, como em "Ninguém sabe se essa cerveja presta" o que, neste momento, não contempla exatamente, nosso objeto de estudo.

Castilho (2014) toma a definição de Leão (1961) que atribui a ideia de condição ou hipótese não só à conjunção $S E$, mas também ao tempo e modo verbais empregados e adota os termos prótase condicionante ou S1 e apódose condicionada ou S2 para as orações condicional e principal, respectivamente.

Com base nas possiblidades de realização, o autor considera três tipos semânticos: real ou factual, construídas com a combinação Indicativo/Indicativo; eventual ou potencial, habitualmente construídas com o esquema Subjuntivo/Indicativo; e contrafactuais ou irreais, que combinam o Subjuntivo/formas em -ria.

Em comum, Moura Neves (2000), Perini (2010) e Castilho (2014) consideram as Orações Condicionais estruturadas de forma a apresentar uma oração principal S2 condicionada à três graus de possibilidade de realização (ou não) conforme a hipótese ou condição proposta pela oração subordinada S1. Todos atribuem à combinação modo-temporal o efeito semântico de declaração dessas possiblidades de realização, sendo que Perini (2010) se diferencia dos demais ao atribuir ao conectivo a regência do modo que será empregado e apresenta uma quarta possibilidade - a introdução de uma forma interrogativa indireta.

\subsection{Sobre a forma interrogativa do enunciado utilizado nos testes}

Visto que os enunciados de nossos testes apresentam uma forma interrogativa, ainda que direta, parece-nos interessante trazer uma discussão a respeito da conjunção SE como introdutória de um enunciado interrogativo.

Encontramos em Bagno (2011) uma análise sobre a partícula SE como conjunção integrante e também como conjunção condicional. Segundo o autor, SE será empregada como 
subordinativa integrante quando há um sentido interrogativo, expresso de forma direta ou indireta (a-b) ou negativa (c), como nos exemplos ${ }^{14}$ :

(a) Você sabe se o Museu fecha às segundas-feiras?

(b) Ele perguntou se o Museu fecha às segundas-feiras.

(c) Eu não sei se o Museu fecha às segundas-feiras.

O uso da condicional SE nessas situações é assim explicado por Castilho (2010, p.357), citado por Bagno (2011, p.894) “Provavelmente, quando fazemos uma pergunta indireta, pressupomos diferentes respostas como hipóteses, o que teria levado a escolher o mesmo vocábulo conectivo em ambas as sintaxes".

Assim, o uso da partícula $S E$ nos enunciados que usamos nos testes, ainda que na forma de interrogativa direta, permite uma variedade de respostas além de um SIM ou NÃO. Ou seja, há uma possibilidade de respostas e reações, porque, na verdade, trata-se, como concluiremos mais adiante, de uma sugestão, proposta ou convite.

\subsection{Sobre as orações interrogativas e a Oração Condicional sem apódose, introduzida pela partícula $E$}

Estudos mais aprofundados sobre as orações interrogativas e a Oração Condicional sem apódose, introduzida pela partícula $E$ não serão apresentados nesta subseção, diferentemente do que veremos na subseção 2.1.2, que trata dos estudos referentes ao Espanhol. Não por considerarmos que estes elementos sejam importantes somente no âmbito do Espanhol, mas por termos encontrado estudos específicos sobre estes somente nas gramáticas espanholas.

\subsection{Sobre a Classificação Sintática das Orações Condicionais}

As Orações Condicionais, quanto a sua classificação sintática, encontram-se no grupo das orações subordinadas adverbiais.

Encontramos em Bagno (2011, p.832) voz para um dos questionamentos que vimos apresentando, com relação às classificações estabelecidas e, de certa forma, cristalizadas nos estudos gramaticais:

Os advérbios são a melhor ilustração possível para algumas das teses que temos defendido nessa gramática: a precariedade das classificações definitivas, a instabilidade inerente à gramática de qualquer língua, os processos ininterruptos de gramaticalização, a possibilidade que as palavras têm de exercerem múltiplas e distintas funções...

A mesma "precariedade das classificações definitivas", da qual padece o advérbio, pode ser estendida à classificação das orações subordinadas adverbiais. Primeiramente, por estarem

\footnotetext{
${ }^{14}$ Exemplos extraídos de Bagno (2011, p. 893)
} 
propensos ao fenômeno da discursivização, os advérbios desviam-se de sua função lexical ou gramatical para servir à organização da fala, como marcadores discursivos ou modalizadores. Em "Felizmente parou de chover" não se trata de atribuir um modo feliz para o tempo, mas uma manifestação do sentimento do enunciador com relação ao clima ${ }^{15}$.

Quanto à relação de subordinação, pesquisadores contemporâneos propõem uma quebra da dicotomia tradicional - subordinação/coordenação - incluindo a correlação como um processo intermediário. Neves, Braga e Hattnher (2008), citados por Castilho (2014, p. 373) "propõem um estatuto próprio para as adverbiais, situando-as entre as coordenadas e as subordinadas" retirando as subordinadas adverbiais do grupo das completivas e adjetivas restritivas.

Os enunciados em questão “¿Y si jugamos a otra cosa?” e “¿Y si pintamos una bailarina?” apresentam uma estrutura aparentemente condicional visto serem introduzidos pela conjunção subordinada "SI/SE". Mas como classificá-las diante da antecipação pela partícula "Y/E", apontada por Bagno (2011) como uma conjunção prototipicamente coordenativa?

Sobre coordenação e subordinação, destacamos em Bagno (2011) os conceitos de Parataxe (coordenação) e Hipotaxe (subordinação). O autor lembra que essas relações se estabelecem por meio de conjunções coordenativas e subordinativas,

que coordenação e subordinação são propriedades semânticas dos enunciados, de modo que é perfeitamente possível construir um período subordinado com o emprego de uma conjunção prototipicamente coordenativa: Faça isso de novo e eu te encho de porrada! (= Se você fizer isso de novo, eu te encho de porrada!) (BAGNO, 2011, p.884)

Segundo o autor, essa combinação de conjunções permite quatro possibilidades de organização sintática:

(a) a hipotaxe adverbial, que se realiza por meio da gramaticalização de elementos de várias classes gramaticais (BAGNO, 2011, p.886);

(b) a correlação, em que estão presentes traços tanto de coordenação quanto de subordinação (BAGNO, 2011, p.887);

(c) a coordenação, que se dá por meio de conjunções também chamadas de conectores, por ligar termos entre si, de caráter verbal ou nominal; e

(d) a subordinação que consiste de "dois processos de nominalização de sentenças, nos quais uma sentença dependente pode ser transposta para a categoria de substantivo e para a categoria de adjetivo." (BAGNO, 2011, p.893).

Retirando as hipotáticas adverbiais do rol de orações subordinadas, restam as orações substantivas e as orações adjetivas. Mas chama nossa atenção que, na relação de tipos de

15 Castilho (2014) detalha a grande variedade de funções desempenhadas pelo advérbio no capítulo 13 Sintagma adverbial. 
correlação, o autor dá como exemplo uma correlação hipotética na forma estrutural SE S1, ENTÃO S2 - Se o sexo não é bom, então nada é bom. (BAGNO, 2011, p.888).

Este exemplo nos leva a uma reflexão: A estrutura SE S1, ENTÃO S2 é tradicionalmente tratada como Oração Condicional no grupo das orações subordinadas. Essa recorrência permite-nos considerar a possibilidade de que o aluno de E-LE possa vir a compreender algo que é hipotético como condicional levado pela instrução formal, o que, segundo comprova Bagno (2011) consiste em uma simplificação.

Ainda a respeito dessa questão sobre subordinação/coordenação, encontramos em Koch (2011) o entendimento de que os conceitos de coordenação e subordinação são decorrentes de critérios meramente sintáticos ou formais. Considerando que "o funcionamento global de uma língua só pode ser devidamente explicado por um estudo integrado dos três componentes. [...] torna-se inadequado falar em orações dependentes (ou subordinadas) e independentes (ou coordenadas)" (KOCH, 2011, p.108).

A autora entende haver uma relação de interdependência, visto que qualquer uma das orações é necessária para a compreensão das demais. Inclusive, destaca que há situações em que a ideia principal se encontra em orações consideradas subordinadas (exemplos 8 e 9) e reafirma que "somente uma abordagem sintático-semântica-pragmática poderá dar solução a estas questões" (KOCH, 2011, p.113):

(8) Desejo que sejas feliz.

(9) Afirmo que não conheço esse indivíduo.

Ao encontro das observações e ideias de Koch (2011), Garcia (2006) questiona a relação de dependência e independência, considerando aspectos semânticos, mais importantes ou efetivos do que os sintáticos visto a orientação argumentativa estar na semântica.

Sobre questões argumentativas, apresentaremos uma discussão na terceira parte desta seção, dedicada a questões sobre compreensão, contexto e recursos argumentativos, visto estas estarem presentes nas duas línguas - Espanhol e PB, ainda que com diferenças na materialidade linguística.

\subsubsection{Estudos referentes ao Espanhol}

\subsection{Sobre a estrutura prototípica das Orações Condicionais}

Para o estudo da estrutura prototípica das Orações Condicionais do Espanhol, destacamos os trabalhos de Fernández Lanza (2008), Matte Bon (1995) e Montolío (1999).

Fernández Lanza (2008), em um estudo metodológico baseado na Lógica Formal, alerta para a diferença entre a implicação que há entre as premissas e a conclusão de um argumento lógico dedutivo e a relação entre antecedente e consequente de uma Condicional. Em sua 
pesquisa com falantes nativos do Espanhol, ele constatou que, apesar de haver implicações lógicas na avaliação dos antecedentes e consequentes, o ato linguístico se dá pela elaboração de forma lógica, que contrasta VERDADE/FALSIDADE, mas se resolve por meio de um conhecimento prévio e uma construção semântica, que atribui o valor de VALIDADE/NÃO VALIDADE.

Essa inter-relação de princípios da Lógica, dados pela estrutura das Condicionais, e conhecimentos situacionais e culturais, trazidos pelos sujeitos da enunciação, confere extrema complexidade a esse tipo de construção.

Matte Bon (1995) volta-se para uma análise focada no uso da língua e afirma que no Espanhol há várias maneiras de expressar condições, com destaque para a relação modo-temporal escolhida pelo falante para externar sua compreensão quanto ao grau de possibilidade de realização ou não da ação enunciada. Basicamente, quanto maior a possibilidade de realização, no presente ou no futuro, ou já efetivada no passado, utiliza-se o modo Indicativo; por outro lado, diante da impossibilidade ou menor probabilidade de realização, a Oração Condicional utilizará verbos no modo Subjuntivo. Nessa acepção, Matte Bon classifica as orações como possíveis ou reais, irreais e eventuais.

Montolío (1999) afirma que as Orações Condicionais são, provavelmente, o tipo mais complexo de expressão composta por constituírem uma das principais formas de o falante expressar sua capacidade de imaginar situações diferentes das reais e, por isso, exigem uma análise que combina elementos gramaticais, semânticos e pragmáticos. Em sua concepção, é questionável ter por base que toda a Oração Condicional implica a formulação de uma hipótese visto que uma condição que se refere a um evento passado não pode ser hipotética, por já ter-se realizado. Assim, a autora considera que uma condição apresenta uma noção mais ampla que uma hipótese e, portanto, as condicionais hipotéticas podem ser consideradas como um subconjunto das Orações Condicionais.

A autora aponta a relação, quase universal, estabelecida entre a ideia de condição e hipótese. Com base nessa relação, as Orações Condicionais introduzidas pela conjunção SE ficam submetidas a um silogismo hipotético ou condicional [se $p$, então q]. Em Se tiver um vestido, vou à festa, ir à festa está condicionado ao fato de eu ter um vestido. Mas essa relação não se reproduz em Se ela é bonita, sou Julia Roberts.

Como uma forma de abarcar esse tipo de enunciação, Montolío (1999) apresenta uma distinção entre condicionalidade e suposição, ao afirmar que "cuando un hablante utiliza una construcción del tipo [si $p, q]$ está estableciendo una suposición y una implicación pragmática entre dos enunciados." (p.3649).

Compartilhamos com Montolío (1999) a distinção entre hipótese e condição, no entanto, não entendemos as hipotéticas como um subconjunto das condicionais, pois acreditamos que 
condicionalidade e hipótese são duas noções distintas ${ }^{16}$. Parece-nos, inclusive, que ela mesma, de certa forma se contradiz, ao falar da relação quase universal estabelecida entre essas duas ideias. Ao apresentar uma terceira possibilidade - a suposição, parece fazer uma crítica ou um questionamento a essa relação estabelecida. Ou seja, o enunciador pede ao seu interlocutor que suponha, por algum tempo, a proposição de $p$ para que possa interpretar $q$. Nessa acepção, Montolío(1999) afirma que a relação que se estabelece não envolve fenômenos existenciais, mas atos de fala. Daí provém considerar a complexidade desta estrutura.

Como se pode observar até o momento, algumas Orações Condicionais apresentadas como exemplos por alguns destes autores não se encaixam nas definições estruturais e pragmáticas que eles mesmos apresentam. Por exemplo, Matte Bon (1995, p.201) afirma que:

Cuando se considera la condición introducida por si como algo que puede haberse realizado en el pasado o que puede realizarse o ser verdad en el presente o en el futuro, el verbo de la oración condicional introducida por si va en uno de los tiempos de indicativo:

[2] - Yo creo que estaban en casa.

o Pero si estaban en casa, ¿’por qué no contestaron?

No exemplo [2], "si estaban en casa" atende às especificações de uma oração antecedente, que apresenta um sentido hipotético, visto que o $S E$ introduz algo que pode ser verdadeiro. Porém, não é tão simples atribuir a “¿por qué no contestaron?” o sentido de consequência, justamente por estar na forma interrogativa.

Ao apresentar este exemplo, Matte Bon (1995) destaca a escolha modo-temporal adotada para a Oração Condicional - o Indicativo [estaban], sem revelar que sentido ele atribui à oração consequente.

Encontramos em Moura Neves (2000, p. 837), de forma explícita, o sentido por ela atribuído a uma oração semelhante, no seguinte exemplo:

\footnotetext{
_ Pois não vinha da Itália.

_ Se não vinha da Itália, então de onde vinha? (ANA)

Assim se pode indicar o processo de condição dos enunciados:

[...]

a) Se/desde que (é um fato que) não vinha da Itália,

b) então (daí, em consequência) de onde vinha?
}

\footnotetext{
${ }^{16}$ Esta distinção nos remete à uma observação de Bagno (2011), com relação à dificuldade em separar uma classe lexical de uma função sintática. O autor afirma que esta é uma das dicotomias que a linguística aplica aos elementos da linguagem com objetivos de análise, mas que, devido à complexidade do processamento linguístico, "só mesmo 'forçando a barra', delimitando fronteiras e isolando os fenômenos temos condições de teorizar minimamente sobre essa fabulosa capacidade cognitiva!" (p.834)
} 
Da mesma forma que no exemplo de Matte Bon (1995), a forma interrogativa, portanto aberta, não possibilita construção de sentido de um fato como consequência, mas de uma hipótese, dúvida ou questão.

Montolío (1999, p.3689) classifica [si p, ¿X q?] como uma "pregunta condicional". A autora apresenta duas possiblidades de uso para tal estrutura: a) a prótase apresenta uma asserção assumida e a pergunta busca a informação que se apresenta na apódose: Si, como usted dice, recibe a todos en la misma consulta, ¿cómo se las apaña para guardar el secreto?; b) a prótase apresenta uma forma verbal de caráter hipotético e a questão, no tempo verbal condicional, busca saber qual seria a possibilidade de atuação ou realização: Si fuese obispo, ¿condenaria el aborto?

A primeira possibilidade se aplica ao exemplo apresentado por Moura Neves (2000). Porém, o exemplo apresentado por Matte Bon (1995) não encontra respaldo em nenhuma das duas possiblidades. Essas ocorrências instigaram ainda mais nossas indagações sobre se esses enunciados devem ser classificados como Orações Condicionais.

Consideramos que orações dessa natureza, com esse tipo de estrutura, foram classificadas e têm sido estudadas/ensinadas como Orações Condicionais, tomando por base tão somente sua introdução pela partícula $S I$ (ou $S E$, no $P B$ ) e sob influência da manutenção de uma organização linear e hierárquica que se cristalizou no meio científico e, por conseguinte, no ensino.

\subsection{Sobre as Orações Condicionais sem apódose, introduzidas pela partícula Y}

Iniciamos este tópico com um questionamento: Quanto à classificação taxonômica, os enunciados dos testes podem ser considerados condicionais? Escandell Vidal (1999) afirma tratar-se de uma Oração Condicional "sin apódosis".

As Orações Condicionais não são introduzidas exclusivamente pela partícula SI. Mas não é esse o fato que provoca a questão apresentada. No caso que apresentamos ¿ $Y$ si jugamos a otra cosa? ou ¿Y si pintamos una bailarina?, tratam-se de enunciados que apresentam somente uma parte da estrutura prototípica de uma Oração Condicional - a prótase sem a apódose.

Conforme Escandell Vidal (1999): “Además de introducir sintagmas nominales, la partícula y puede introducir oraciones condicionales sin apódosis, que presentan un nuevo supuesto que el emisor somete a la consideración del destinatario" (p.3955).

A autora afirma que a função da partícula $Y$ é introduzir um novo tema esperando do interlocutor o aporte de uma informação a respeito ${ }^{17}$. Este entendimento vem ao encontro daquele apresentado por Montolío (1999), com relação à implicação pragmática, visto que o

\footnotetext{
${ }^{17}$ Chamamos a tenção para uma distinção que Escandell Vidal (1999) faz entre a conjunción copulativa $Y$, em que o elemento introduzido depende do turno anterior da conversa, e a partícula $Y$, como introdutora de um novo tema e, portanto, independente, além da função introdutora de Orações Condicionais sem apódose.
} 
interlocutor terá que aceitar a suposição $p$ e, para além de interpretar $q$, terá que complementar a ideia do enunciador.

Aproxima-se dessa mesma função introdutória a consideração apontada pela RAE (2010), no item "La coordinación copulativa":

Usada al comienzo de un período, la conjunción y se interpreta como marca de ENLACE EXTRAORACIONAL con lo dicho o pensado anteriormente. En COMIENZO ABSOLUTO se emplea para abrir discursos o para encabezar réplicas. Su valor de enlace copulativo se atenúa en estos contextos y las expresiones que introduce pueden expresar reticencia, ironía o contrariedad, entre otras nociones: iY qué sórdida me resulta desde aquí Inglaterra! (Villena, L. A., Burdel). (p. 609)

No entanto, Escandell Vidal (1999) não apresenta nenhum argumento ou aprofundamento para a afirmação de que além de introduzir um novo tema, a oração introduzida pela partícula $Y$ seja uma Oração Condicional, contrariando todos os trabalhos consultados que afirmam existir nesse tipo de oração uma relação de condicionalidade, hipótese ou suposição entre dois enunciados - o antecedente e o consequente.

\subsection{Sobre a forma interrogativa}

Montolío (1999, p.3689) considera que

Al igual que el imperativo, la interrogación constituye una forma de interpelación al interlocutor, por lo que estas estructuras aparecen, obviamente, en contextos dialógicos, y juegan un importante papel en la negociación conversacional; de hecho, cuando aparecen en corpus de lengua escrita, lo hacen en entrevistas o en las invocaciones al interlocutor que lleva a cabo la publicidad. Todos los ejemplos muestran que el hablante utiliza la prótasis para introducir y presentar la motivación o justificación de la pregunta, y guiar así a su interlocutor en relación tanto a por qué se lleva a cabo la pregunta cómo, en consecuencia, respecto a cuál es la respuesta que se espera.

Partindo do princípio de que o objetivo do enunciador, nos enunciados que compõem nosso objeto de estudo ${ }^{18}$, não é o de solicitar ao destinatário uma informação que aquele não possui, podemos afirmar que, ainda que na forma interrogativa, este enunciado não pode ser considerado uma pergunta. Conforme Escandell Vidal (1999)

Si la finalidad de una pregunta es solicitar al destinatario que proporcione una información de la que se carece, resulta claro que ni todas las interrogativas son preguntas, ni todas las secuencias que pretenden que el destinatario dé una determinada información tienen que presentar, necesariamente, una formulación interrogativa." (p. 3931-grifo nosso).

\footnotetext{
${ }^{18}$ ¿Y si jugamos a otra cosa? / ¿Y si pintamos una bailarina?
} 
Entendemos, portanto, que os enunciados utilizados em nossos testes são apresentados de forma interrogativa como uma pergunta retórica. Segundo Escandell Vidal (1999)

[...] los enunciados interrogativos pueden utilizarse para introducir un tema nuevo, como en el ejemplo de (74)

- ¿Y Paco?

_ Salió a comprar el periódico.

Para ello, es necesaria la presencia de la partícula y, que precisamente marca explícitamente como tema nuevo al constituyente que la sigue." (p. 3955)

A introdução do tema, conforme apontado por Escandell Vidal (1999), se materializa na forma habitual de apresentação das Orações Condicionais, em que a prótase antecede a apódose. Montolío (1999) explica que dessa forma se introduz a informação que está sendo compartilhada.

Neste sentido, é relevante o que afirma Haimann (1978), citado por Montolío (1999), ao analisar certos comportamentos das Orações Condicionais, considerando a noção de tema como informação compartilhada ou pressuposta, o autor identifica uma semelhança entre prótases condicionais e orações interrogativas, "ya que tanto en unas como en otras el hablante pretende que el oyente acepte el contenido como 'dado'" (MONTOLíO, 1999, p.6667).

Especificamente, com relação a orações interrogativas introduzidas pela partícula $Y$, na gramática da RAE (2010), encontramos que:

Se asimilan a las condicionales suspendidas, por cuanto mantienen su carácter hipotético, las interrogativas encabezadas por la conjunción y en las que se propone algo, como ¿Y si lo dejamos para otro día?, o se conjetura que pueda ser cierto algún estado de cosas: ¿Y si estuviéramos todos equivocados? (p.903).

Destacamos o sentido de "proposta", atribuído a esta construção, que vem ao encontro do que declararam ter compreendido os informantes dos nossos testes, conforme se detalhará no Capítulo 2.

No entanto, quando a oração interrogativa vem introduzida pela partícula SI, a RAE (1999) destaca como única combinação modo-temporal possível, as formas verbais do modo condicionado (cantaré, cantaría) visto serem "precisamente incompatibles con las prótasis condicionales". Como nos exemplos ${ }^{19}$ :

¿Si estaré yo tan lelo como este pobre hombre? (85.1879).

¿Si sus ojos estarían distraídos al fijarse en mí? (1.180).

¿Si habré yo visto visiones? (1.180).

${ }^{19}$ Transcritos de RAE (1999), p. 380 
¿Si habría hecho el idilio trapístico más efecto que los otros? (85.1809).

Novamente, colocamos em questão a afirmação de Escandell Vidal (1999) quanto à possibilidade de estarmos tratando com um tipo de Oração Condicional sem apódose. Conforme a RAE (1999) tais orações não devem ser nem "classificadas" como condicionais.

\subsection{Sobre a Classificação Sintática das Orações Condicionais}

Segundo classificação encontrada na RAE (2010), as Orações Condicionais fazem parte das "subordinadas adverbiales impropias" (p.898), muito próxima da classificação encontrada nas gramáticas brasileiras - subordinadas e adverbiais.

No entanto, a mesma RAE (2010, p. 899) aponta a condição que "De hecho, no existen en español advérbios condicionales" o que, de certa forma, permite questionar a classificação "adverbial", para estas orações.

Por outro lado, a subordinação também é controversa, visto que

Los períodos condicionales y concesivos contienen subordinadas que no están insertas o incluidas en las principales. Así, la prótasis de una condicional no está incluida en la apódosis, mientras que una subordinada sustantiva lo está en la oración principal y constituye por tanto un segmento de ella. (RAE, 2010, p. 899).

Ou seja, no caso das Orações Condicionais, os dois elementos têm papel fundamental na composição da estrutura. Nenhum dos dois pode ser eliminado sem alterar ou comprometer o sentido do enunciado. O que se estabelece é uma relação de "interdependência", conforme a RAE (2010). Vejamos o exemplo: "Si perdió el tren de las 7.30, llegó tarde." no implica "Ilegó tarde" (p.899).

Rojo (1978) citada por Montolío (1999) considera que "la relación sintáctica que establecen los miembros de una condicional no es de subordinación, sino de interordinación" (p.3648).

Estas ponderações nos dão maior embasamento para questionar a classificação recorrentemente encontrada nas gramáticas e que, da forma como são tratadas na instrução formal, podem comprometer a possibilidade de uma reflexão crítica e uma compreensão pragmática, ou sequer a função desses enunciados, por parte dos aprendizes.

Estamos de acordo com Bruno (2004) quando afirma que "Os professores se fixam na forma e não em melhorar a capacidade discursiva do aluno, potencializando sua capacidade de comunicação e compreensão em língua estrangeira" (p.41). Ainda de acordo com a

\footnotetext{
${ }^{20} \mathrm{Tal}$ classificação remete, novamente, ao que discute Bagno (2011) com relação à necessidade de separação entre classe e função, conforme apontamos na nota de rodapé 16.
} 
professora, é preciso estar atento ao valor que estas formas assumem dependendo do contexto.

\subsubsection{Sobre compreensão, contexto e recursos argumentativos}

As descrições que apresentamos na primeira parte desta seção ilustram a complexidade e a particularidade dos enunciados utilizados nos testes. Em função disso, outras teorias foram mobilizadas para a leitura e análise dos dados da pesquisa, apresentadas no Capítulo 2. Para que o leitor possa compreender tais escolhas, tecemos, na sequência, algumas considerações.

Montolío (1999) aponta para diversos estudos que identificam uma relação de implicação entre as duas orações que compõem uma estrutura condicional [se $p, q$ ] considerando que não se trata de uma relação entre fenômenos existenciais, mas entre dois atos de fala. Segundo a autora, há uma implicação pragmática entre os dois enunciados, visto que ao usar a partícula $S I / S E$ o falante solicita a seu interlocutor que, mentalmente, suponha $p$ para dar sentido a $q$.

No exemplo que ela chama de "problemático": Si te encuentras mal, nuestro vecino el médico acaba de llegar a casa ${ }^{21}$, há uma implicação entre estar doente ou se sentindo mal e a necessidade de buscar um médico, consequente de um conhecimento de mundo e um senso comum, que deve ser partilhado por ambos os interlocutores para que haja um sentido.

À luz de Montolío (1999), entendemos que os enunciados que compõem nosso objeto de estudo apresentam um importante componente pragmático ${ }^{22}$ que vem ao encontro de nossa hipótese sobre a influência do contexto para a compreensão.

A fim de delinear os conceitos de compreensão e contexto, fundamentais para a análise dos enunciados e das respostas dos participantes aos testes, em uma primeira subseção partiremos dos estudos da Teoria da Compreensão, de Parret (1985), que discute a compreensão a partir de processos de interação, em situação de diálogo. Apresentaremos uma interface com a proposta de Teoria de Contexto Verbal, de Ibañez (1990), que examina o conceito de contexto a partir da construção de significados por meio de textos, orais ou escritos e discutiremos a Teoria do Contexto, proposta por van Dijk (2007, 2012), numa perspectiva sociocognitiva.

Ainda com relação ao componente pragmático e considerando o fator interacional, nos termos de Parret $(1984,1985)$, estamos de acordo com Koch $(2011$, p. 23) ao defender que a Pragmática deve ser vista como "o estudo da atividade interindividual realizada no discurso",

\footnotetext{
${ }^{21}$ Exemplo citado em Montolío (1999, p.3649)

${ }^{22}$ Cf. Charaudeau \& Maingueneau (2016, p. 393-394) "De uma maneira geral, quando se fala em componente pragmático ou quando se diz que um fenômeno está submetido a "fatores pragmáticos", designa-se com isso o componente que trata de processos de interpretação dos enunciados em contexto". (grifos do autor).
} 
este tomado como ação verbal dotada de intencionalidade ${ }^{23}$ e que constitui uma unidade pragmática e uma atividade capaz de produzir efeitos e reações, por meio da argumentação ${ }^{24}$.

Defendemos que os elementos que compõem a estrutura não prototípica das Orações Condicionais dos enunciados que trazemos para análise - introdução pela partícula $Y / E$ e a forma interrogativa - constituam uma estratégia argumentativa. Visto termos como um de nossos objetivos checar se, para além das questões sistêmico-formais da língua espanhola, há influência de elementos discursivo-pragmáticos no eixo produção-compreensão ${ }^{25}$ dos participantes, desenvolvemos, na segunda subseção, um arcabouço teórico voltado para estes aspectos, com ênfase nos operadores argumentativos (PORTOLÉS, 1988; KOCH, 2011) e nas estratégias de cortesia e atenuação (BRIZ, 2013).

\subsubsection{Compreensão e contexto}

Inicialmente, chamamos a atenção para o conceito de contexto que predomina no senso comum e que consideramos inadequado para os interesses de nossa proposta de trabalho. Nas palavras de van Dijk (2007, p. 295):

Muito do que é tradicionalmente chamado de 'contexto' é o conhecimento que as pessoas trazem para ter uma conversa. Deve-se notar, no entanto, que este tipo de conhecimento específico ou geral, conforme representado em modelos mentais e as representações sociais, respectivamente, serve para entender sobre o que é o discurso: ele é a base semântica do discurso. Aqui, no entanto, estamos lidando com um outro tipo de 'conhecimento', ou seja, o conhecimento sobre a situação comunicativa [...]: os participantes, suas propriedades relevantes, relações e ações na configuração atual. Poderíamos simplesmente chamar este de conhecimento contextual ou pragmático." ${ }^{26}$ (tradução nossa).

Consideramos que o mesmo ocorre com o entendimento comum que se têm de compreensão, termo normalmente empregado como sinônimo de decodificação, como afirma Bruno (2004, p. 27):

\footnotetext{
23“A noção de intenção aqui é puramente linguística, determinada pelo sentido do enunciado". (KOCH, 2011, p.19).

${ }^{24}$ Entendemos argumentação tal como Koch (2011, p.21): “[...] partindo do postulado de que a argumentatividade está inscrita no uso da linguagem, adota-se a posição de que a argumentação constitui a atividade estruturante de todo e qualquer discurso, já que a progressão deste se dá, justamente, por meio das articulações argumentativas, de modo que se deve considerar a orientação argumentativa dos enunciados que compõem um texto como fator básico não só de coesão, mas, principalmente, de coerência textual.".

${ }^{25}$ Eixo produção-compreensão, nos termos de Bruno (2006), conforme citado na nota de rodapé 7.

26 "Much of what is traditionally called the 'context' is the knowledge people bring to bear in conversation. It should be noted though that this kind of specific or general knowledge, as represented in mental models and social representations, respectively, serves to understand what the discourse is about: it is the basis of the semantics of discourse. Here, however, we are dealing with another kind of 'knowledge', namely knowledge about the current communicative situation [...]: the participants and their relevant properties, relations and action in the current setting. We might simply call this contextual or pragmatic knowledge." (VAN DIJK, 2007, p.295)
} 
Em sala de aula, pode-se dizer que se trabalha a compreensão como um exercício didático, reflexo de uma conduta pedagógica que visa trabalhá-la como uma das habilidades linguísticas a serem desenvolvidas em um projeto didático: produção e compreensão oral e escrita. Temos em muitos casos a compreensão, nestes moldes, como uma tarefa a ser executada durante uma parte do tempo de uma aula, uma compreensão que muitas vezes se limita, inclusive, à compreensão/discriminação auditiva ou, no caso de textos lidos, à determinação dos clássicos "o quê, quem, quando, onde, como, etc.".

Nos itens seguintes, desenvolvemos as concepções de Parret (1985), Ibañez (1990) e van Dijk (2007, 2012) sobre compreensão e contexto. Tais conceitos são tratados como complementares pelos três autores. No nosso entender, tratam-se de noções indissociáveis, sob o ponto de vista da interação e de elaborações cognitivas.

\subsection{A Teoria da Compreensão de Parret (1985)}

Parret (1985) destaca a interação como elemento fundamental do processo dialógico e um forte conceito para a proposição de sua Teoria da Compreensão. Questiona a representação clássica do fluxo da informação, que considera haver uma simetria entre produção e compreensão e defende que "uma teoria da compreensão deve ser assimetricamente central em relação a qualquer teoria de produção, sendo, portanto, o núcleo de uma teoria da interação discursiva e do diálogo" (PARRET, 1985, p. 160).

O autor entende a compreensão como sendo "um conjunto de estratégias práticas que nos possibilitam inferir ${ }^{27}$ a significância, limitada pelo contexto, de fragmentos linguísticos determinados pela interação" (PARRET, 1985, p.161), dependente de um "esquema de aceitação" entre o falante e o ouvinte ${ }^{28}$. Trata-se de mobilizar estratégias baseadas em processos racionais e que se relacionam a valores constituídos social e culturalmente, possibilitando ao ouvinte "aceitar" o enunciado do falante, desde que ambos compartilhem do mesmo conhecimento linguístico. O significado do enunciado tem um co-texto ou "texto que circunda" (PARRET, 1985, p.163), que tem como função desfazer ambiguidades, porém de maneira limitada, visto ter uma estrutura macro-gramatical. Neste caso, a contextualização será mais eficiente para a desambiguação por meio do processo de inferência da significação das sequências dialógicas. Mas é a co-textualização gramatical que oferecerá subsídios para essa inferência.

O autor afirma que "os membros de uma comunidade compreendem as sequências em uma situação dialógica somente se eles interpretam os contextos nos quais esses fragmentos de diálogo são produzidos." (PARRET, 1985, p.161). Esta afirmativa reforça a importância dada

\footnotetext{
${ }^{27} \mathrm{Em}$ acordo com Bruno (2004, p.29), pode-se considerar nesta terminologia a influência do modelo proposto por Paul Grice e David Lewis, ao qual Sperber \& Wilson (1994a, p. 13) denominam modelo inferencial. Segundo estes autores, a compreensão é de natureza inferencial (SPERBER \& WILSON, 1994a, p.87).

${ }^{28}$ Sobre o "esquema de aceitação", identificamos uma relação com o que diz Marcuschi (1996) e van Dijk (2012), referente à necessidade de que os sujeitos compartilhem interesses e conhecimentos, não só linguísticos, mas principalmente, sociais e culturais (pragmáticos).
} 
ao contexto e sua influência sobre a compreensão. Mas, ao mesmo tempo, elimina outras possibilidades ou a importância de outros elementos para a compreensão, dando a entender que Parret acredita que a compreensão se concretiza com alguma facilidade e efetividade, já que a contextualização dará conta da ambiguidade, como se o falante tivesse controle sobre os diversos fatores que interferem na compreensão. Ou seja, a compreensão está condicionada a uma colaboração mútua e à possibilidade de interpretação, pelos sujeitos envolvidos, dos contextos em que os diálogos são produzidos.

Trata-se de compartilhar de um conhecimento pragmático, ou seja, "A interpretação e reciprocidade de perspectivas dos membros de uma comunidade fazem com que seja possível uma significação ser praticamente inferida quando há compreensão" (PARRET, 1985, p.167). Assim, há de se considerar esta condição como fator complicador para a compreensão, quando se tratar de falantes do PB, no papel de aprendizes de E-LE, submetidos a enunciados produzidos em contexto linguístico e cultural distinto do seu.

Parret (1984) afirma que uma "competência comunicativa pragmática" é uma competência de compreensão e esta é uma faculdade, uma capacidade, uma habilidade extrínseca. A compreensão, mais que uma operação psicológica, é uma operação-no-mundo. Aquilo que se compreende é um correlato de sentido de três componentes: um operador universal de racionalidade, uma estrutura modal e um conteúdo proposicional $\rightarrow$ "É racional/razoável (operador de racionalidade universal) que eu/você julgue/deseje (estrutura modal) que p".

A partir desses três componentes, o autor identifica três diferentes contextos que podem ser construídos:

- do operador de racionalidade, o contexto é a comunidade dos utilizadores e as suposições prévias que essa comunidade discursiva oferece aos seus membros;

- da modalidade, o contexto são as circunstâncias interacionais. Opiniões que os utilizadores têm em uma situação comunicativa relacionadas aos objetivos e necessidades de um em relação ao outro;

- do conteúdo proposicional, o contexto consiste das crenças partilhadas entre os utilizadores.

Estes três contextos são fruto da combinação de cinco tipos de contexto que, caracterizam o que ele chama de "atitude pragmática", de acordo com a orientação que lhe é dada, conforme sintetizamos no Quadro1, a seguir: 
Quadro 1: Tipos de Contexto em relação a Tipos de Orientação Pragmática

\begin{tabular}{|l|l|}
\hline \multicolumn{1}{|c|}{ Tipos de Contexto } & \multicolumn{1}{c|}{ Orientações da pragmática } \\
\hline Co-textual & Do texto \\
\hline Existencial & Lógica indicial \\
\hline Situacional & "mundos possíveis" \\
\hline Acional & Orientada sociologicamente \\
\hline Psicológica & Teoria dos atos de fala \\
\hline
\end{tabular}

Fonte: PARRET (1984)

No contexto co-textual, a sintaxe se atém à sentença e a semântica não vai além da proposição. Em contraste às gramáticas sentenciais e proposicionais, o co-texto tem um papel de decodificação em uma relação com os outros tipos de contextualidade.

Contextos existenciais são expressos por sequências linguísticas que representam objetos, estados de coisas ou acontecimentos, do mundo real ou dos mundos possíveis. A relação com o contexto existencial leva a dois tipos de pragmática:

- $\quad$ Indicial - na qual os objetos, estados de coisas e acontecimentos no mundo "são 'indiciados' ou relativizados com respeito a sua localização pessoal e espaçotemporal" (PARRET, 1984, p.40).

O deslocamento da semântica para a pragmática ocorre quando o espaço-temporal ocupado pelos interlocutores, ao qual a expressão linguística faz referência, é considerado como índice desse contexto existencial. Esse deslocamento trata do contexto referencial ao passar da unidade à qual a expressão linguística faz referência para considerar quem fala e quem compreende, bem como sua localização espaçotemporal como índice do contexto existencial.

- $\quad$ mundos possíveis - "não só o mundo real, mas todos os mundos possíveis podem ser tomados como contextos existenciais de sequências linguísticas" (PARRET, 1984, p.41). Parret (1984) defende que um mundo possível só poderá ser um referente se houver uma intermediação psicológica, como a imaginação ou a construção de conceitos.

O contexto situacional relacionado a convenções sociais, hierarquia e autoridade do falante, como determinante dos conteúdos significativos das sequências linguísticas. Consiste no cenário social das instituições e nos ambientes do dia-a-dia, normatizados por regras e 
convenções sociais e culturais, que "dão forma principalmente às propriedades convencionais de unidades textuais amplas, e às estruturas argumentativas e persuasivas do discurso." (PARRET, 1984, p.41). A autoridade reconhecida por uma micro-comunidade, por exemplo, determina os conteúdos significativos das sequências linguísticas.

Sobre o contexto acional, Parret (1984) lembra que Austin (1962) defende que as sequências linguísticas não expressam ações. Elas são as ações. A sentença tem, então, uma força ilocucionária.

Numa perspectiva pragmática, a Teoria dos atos de fala, na qual a língua é vista como uma ação, elabora que a) as condições de produção de um ato de fala estão submetidas a regras e b) que a ação linguística é uma ação intencional.

O falante tem uma intenção e pretende que ela seja reconhecida. Acrescenta-se então a condição de interação. Os demais participantes da situação comunicativa constituem o contexto de produção do discurso. Na interação se dá uma troca na produção, de constituição de contexto de forma sucessiva e alternada. "nenhuma comunicação, nenhum reconhecimento de intenções é possível sem uma interação cooperativa e coordenada.", segundo Grice (1968), citado por Parret (1984).

Ou seja, as "ações linguísticas dos outros falantes que participam da situação comunicativa, são o contexto de produção do meu discurso, agindo com uma capacidade produtiva semelhante, e assim sucessivamente." (PARRET, 1984, p.42).

O contexto psicológico, ao considerar o discurso como ação e os atos de fala como ação intencional, leva a incorporar categorias mentais e psicológicas à teoria pragmática da língua. Compõem o contexto psicológico intenções, crenças e desejos, desde que se traduzam em interações, como parte da atividade mental realizada para a compreensão e produção de processos linguísticos determinados gramaticalmente.

Assim, Parret (1984, p.44) considera que os contextos NÃO SÃO conjuntos de variáveis autônomas e independentes do processo de comunicação entre indivíduos. São dinâmicos e frutos de uma competência criativa de compreensão baseada em estratégias.

As estratégias baseiam-se em processos racionais. São inferenciais e não-lógicas, porque são realizadas no e por meio do uso da língua natural. A atividade inferencial é um procedimento de transposição de sentido, diferente da inferência lógica que "pressupõe uma metalinguagem em que todo sentido pode ser finalmente traduzido".

As razões daqueles que raciocinam no e pelo discurso e, portanto, realizam inferências a fim de compreender, são razões 'não naturais', prescritivas. A semântica clássica trabalha com um conceito bipolar de racionalidade: pensamento $\leftrightarrow \rightarrow$ realidade. A pragmática inclui um terceiro vértice: a intermediação do conceito de um ser racional como raciocinador. Esse 
terceiro elemento com um "toque antropológico" implica que as estratégias relacionam-se a valores.

A título de síntese, podemos entender que, para Parret:

- a compreensão é um conjunto de estratégias práticas que nos possibilitam inferir a significância, limitada pelo contexto, de fragmentos linguísticos determinados pela interação. Essas estratégias estão baseadas em processos racionais e relacionam-se a valores social e culturalmente constituídos;

- a compreensão se dá por meio da combinação de contextos, estes constituídos por elementos linguísticos e de caráter social e psicológico;

- a compreensão é um processo de inferência prática que os contextos tornam dinâmicos por razões de ordem psico-pragmática. Elementos de ordem psicopragmática estão relacionados a aspectos verbais e extra verbais, concomitantemente;

- a con-textualização faz parte do processo de inferência que permite a significação, no entanto, é a co-textualização que molda o significado do qual a significação será inferida;

- o co-texto é o "texto que circunda" e intervém quando ocorre a ambiguidade gramatical, no entanto, por sua estrutura macro-gramatical, está limitado nessa desambiguação.

\subsection{A Teoria do Contexto Verbal de Ibañez (1990)}

Ibañez (1990) propõe uma Teoria do Contexto Verbal, partindo do princípio de que o texto, oral ou escrito, é o resultado de uma composição de signos linguísticos organizados de forma a expressar uma intenção do seu autor. Destacando uma distinção entre função comunicativa (ilocução) e função expressiva, Ibañez (1990) deixa clara sua intenção de contemplar qualquer forma interacional, com ou sem função comunicativa, como é o caso do texto literário.

A proposta desta teoria parte da hipótese de que um texto não traz um significado em si. É sua estrutura que tem a função de "evocar" um significado ${ }^{29}$ que será elaborado pelo receptor, em determinado contexto, a partir de informações prévias que este possui. A fonte dessas informações é ao que Ibañez (1990) denomina "contexto do evento verbal".

\footnotetext{
${ }^{29}$ Quando Ibañez (1990) diz que a estrutura "evoca" um significado (mantivemos o termo porque é o que ele utiliza), entendemos que, na verdade, ele poderia estar falando de sentido. Em nossa forma de interpretar, a relação entre os elementos da estrutura + o contexto é que evocaria um sentido. Dependendo da época e das opções teóricas que se faz as leituras são diferentes. Nossa interpretação passa pela relação que estabelecemos com a Análise do Discurso e, também, pela diferenciação que, a partir do Pensamento Complexo de Edgar Morin $(2003,2006)$, fazemos entre significado (restrito, isolado, uma parte) e sentido (que é formado a partir dos subsistemas da estrutura, o todo). O próprio Ibañez (1990) parece nos incentivar nessa direção ao esclarecer: "y en lo que sigue con el término 'significado' me refiero al significado real de un texto, es decir con el que fue concebido por su autor o con el que es recibido por su lector u oyente en circunstancias reales de actualización. Este concepto de significado coincide con el de la SEMÁNTICA DE LA COMUNICACIÓN o de ACTOS DE HABLA" (IBAÑEZ, 1990. p.3).
} 
O contexto será, portanto, um "provedor de informações", no sentido de criar expectativas relativas aos significados que irão se construindo durante a produção do texto, originadas de experiências individuais e/ou coletivas dos participantes ${ }^{30}$, independentemente do tipo textual (que interpretamos como narrativo, descritivo, argumentativo, por exemplo) ${ }^{31}$.

Ibañez (1990) chama a atenção para a falta de consenso conceitual para a noção de contexto, apesar de sua reconhecida importância para a interpretação do texto. Em sua opinião, o contextualismo inglês, ao tratar indistintamente contexto e contexto situacional, não abrange de forma suficiente a questão, pois, no entender de Ibañez (1990) este é um componente daquele. Tampouco o modelo de Halliday (1974), conforme cita, Ihe parece abrangente o suficiente, mesmo contemplando a interação entre fatores textuais e contextuais, pois restringe-se ao co-texto e à situação comunicativa. Na opinião de Ibañez (1990), é a Psicologia Social da Linguagem que apresenta uma definição "mais convincente", por entender contexto como o conjunto de elementos, linguísticos (co-texto) ${ }^{32}$, não línguísticos e situacionais, que interferem cognitivamente na construção de significados. O esquema a seguir representa essa sua forma de conceituar contexto.

30 No texto analisado, lbañez(1990) utiliza diferentes termos (receptoremissor/actante/interactante/participante) predominando o termo "actante". Porém, o autor não apresenta, formalmente, uma definição ou justificativa (filiação teórica) para essa variação. Encontramos em Galisson \& Coste (1983, p.20-21), no Dicionário de Didáctica das Línguas, uma relação com o teatro, onde o "actante" referese ao "actor". Observamos que o termo "actante" (usado 8 vezes), aparece sempre que Ibañez (1990) se refere ao participante de um ato comunicativo, com um caráter individual. Por sua vez, o termo "interactante" (usado 3 vezes) aparece nos trechos em que o autor descreve ou discorre sobre a relação interacional que se estabelece entre os participantes em um processo discursivo, verbal ou não, por ocasião das trocas que se realizam em um determinado contexto.

${ }^{31}$ Ibañez (1990) não deixa claro o que é, para ele, "tipo textual". Nossa interpretação se dá considerando a seguinte referencia: "El contexto produce expectativas en cuanto a los tipos de textos que pueden ocurrir en él $y$, si se trata de un texto ya en desarrollo, expectativas en cuanto a los significados que se van construyendo" (IBAÑEZ, 1990, p. 5-6).

${ }^{32}$ Maingueneau (2008, p.26) denomina co-texto como contexto linguístico. "São sequências verbais que mobilizam a memória do intérprete (pelos antecedentes) que relacionam uma unidade com outra no mesmo texto". O que poderíamos interpretar como estrutura, como pensado por Durand (2002, p. 10 apud BRUNO, 2018, p. 387). O antropólogo afirma que “[...] toda a 'estrutura' implica por definição uma relação entre elementos que são os seus subsistemas, e isto até o infinito [...]". 


\section{Quadro 2: Esquema apresentado por Ibañez}

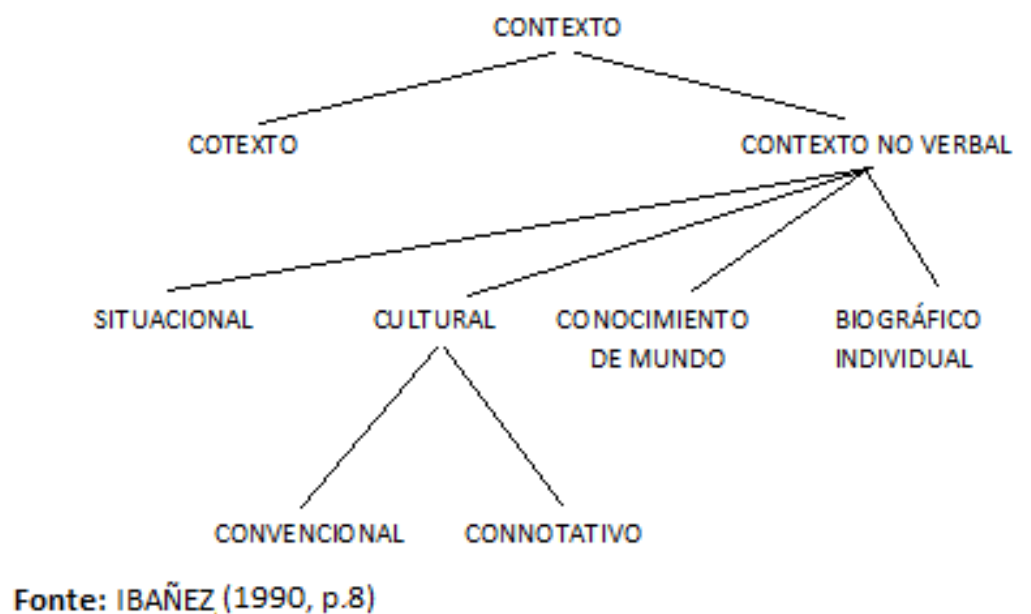

Onde:

COTEXTO ${ }^{33}$ - Elementos de coerência e coesão, presentes antes e depois do texto em questão, que constituem objetos da gramática textual;

CONTEXTO SITUACIONAL - Todos os fatores percebidos pelo interactante, de forma consciente ou inconsciente, na situação de interação - "una construcción mental con elementos de la realidad circundante en la interación" (IBAÑEZ, 1990, p. 10);

CONTEXTO CULTURAL - código resultante da experiência social de uma determinada comunidade. Convencional, quando trata da conduta dos actantes em determinada situação de interação verbal; e conotativo, quando reúne condutas sociais de caráter estável.

CONOCIMIENTO DE MUNDO - faz parte das condutas sociais de caráter transitório. É o conjunto de informações sobre o meio-ambiente e o meio social necessárias para o êxito da interação - identificação da intenção comunicativa e para a construção de sentido do texto.

BIOGRÁFICO INDIVIDUAL - contexto relacionado à vivência do actante e, por conseguinte, a forma como ele percebe os eventos. A percepção está relacionada à relevância que determinado evento tem em uma determinada situação de interação. "La percepción de eventos es controlada por la resultante biográfica (código de percepción y campo de percepción), siendo el código de percepción el 'como' se percebe y el campo de percepción el 'que' se percebe" (IBAÑEZ, 1990, p.14).

Os elementos situacionais são percebidos de forma consciente ou inconsciente pelos participantes desde que estes os considerem relevantes para o êxito da interação. Esse aspecto de relevância coincide com Sperber e Wilson (1994b) que identificam que "para ser

\footnotetext{
${ }^{33}$ O termo COTEXTO está grafado na norma da língua espanhola. Mas a definição apresentada por Ibañez (1990) nos permite afirmar tratar-se do mesmo conceito de co-texto, já citado em Parret (1985). Assim, optamos por manter a grafia em Espanhol para os componentes do esquema apresentado no Quadro 2.
} 
relevante em um contexto, uma suposição tem que estabelecer, de alguma maneira, uma conexão com esse contexto" ${ }^{34}$.

Por essa razão, o autor afirma que o contexto situacional é uma criação individual, "uma construção mental com elementos da realidade circundante à interação"35 (IBAÑEZ, 1990, p.10). Considerando que o que é relevante para um participante pode não ser relevante para o outro, acontecerá uma "negociação de contexto", imprimindo um caráter dinâmico ao contexto. As considerações relativas a esse dinamismo do contexto situacional, bem como à sua origem em um processo cognitivo, parecem ter sua fonte em estudos anteriores de van Dijk ${ }^{36}$, dos quais falaremos no próximo item, desta subseção.

Segundo Ibañez (1990), o sucesso ou o fracasso do processo comunicativo dependerá, portanto, do conhecimento do meio ambiente e do meio social que os participantes compartilham, denominado contexto cultural. Malinowski (apud IBAÑEZ, 1990, p. 11) propõe para o contexto cultural uma composição por dois subsistemas: um convencional e um individual. O convencional se constitui de regras tacitamente determinadas para a conduta social dos indivíduos de uma determinada comunidade. O individual consiste na forma particular como cada membro dessa comunidade percebe os eventos, em função de suas vivências.

Desta forma, as experiências prévias dos participantes, seu conhecimento de mundo e as convenções sociais da comunidade à qual pertencem provocam uma reconstrução ou adaptação do contexto, levando a novas interpretações daquele texto, em processo circular. Esta forma de perceber a relação entre texto e contexto se assemelha à relação entre compreensão e contexto proposta por Parret (1985), à qual este chamou bi-direcional. Ou seja, a compreensão "cria" seu contexto e este influencia na compreensão. O diálogo, "como um caso paradigmático de interação verbal e intersubjetividade semiótica", determina o contexto, que, por sua vez, restringe a significação dialógica.

Como forma de síntese, destacamos as seguintes formulações de lbañez (1990):

- o contexto é o resultado de uma composição de signos linguísticos organizados de forma a expressar uma intenção do autor;

- o receptor constrói um significado "estimulado" pelo texto, complementando com informações que ele já trazia. Ou seja, o texto funciona como um "provedor de informações evocadas pelo texto";

- o contexto é um conjunto de elementos, linguísticos (palavras), não linguísticos (gestos) e socioculturais (individual e institucional), que interferem cognitivamente na

\footnotetext{
34 "para ser relevante en un contexto un supuesto tiene que guardar de alguna manera alguna conexión con ese contexto." (SPERBER \& WILSON, 1994b, p.156).

35 "una construcción mental con elementos de la realidad circundante en la interacción." (IBAÑEZ, 1990, p.10)

${ }^{36}$ Citado por Ibañez (1990, p.11), van Dijk (1984, p. 274) define contexto como uma sequência de acontecimentos que variam no tempo.
} 
construção de significados. Segundo o autor, o sucesso ou o fracasso do processo comunicativo dependerá, portanto, do conhecimento do meio ambiente e do meio social que os participantes compartilham, denominado contexto cultural.

Assim, em comum, Parret (1985) e Ibañez (1990), entendem contexto como o conjunto de elementos, linguísticos (co-texto), não linguísticos e situacionais, que interferem cognitivamente na construção de significados, e defendem haver um movimento dinâmico de (re)elaboração do contexto em um processo de recursividade ou retroalimentação, como forma de promover a compreensão.

Este mesmo tipo de movimento se observa no "eixo produção-compreensão". Segundo Bruno (2006), dentro do processo de aquisição de uma língua estrangeira, o aprendiz testa hipóteses com base em seus conhecimentos prévios em confronto com os novos conteúdos ${ }^{37}$.

\subsection{A Teoria do Contexto de van Dijk $(2007,2012)$}

Van Dijk (2007), como Ibañez (1990), considera que "a noção de contexto apresenta um papel controverso no estudo do discurso, da conversação e da interação em geral" (VAN DIJK, 2007, p. 282) ${ }^{38}$. Ele identifica contextos sendo descritos como a situação social diferenciados entre local - em uma situação imediata de produção, como a interação face a face, ou global - em uma situação mais abrangente, envolvendo também grupos ou comunidades, em um maior intervalo de tempo ou espaço de localização. Considerando que interações locais e globais ocorrem ao mesmo tempo, o autor considera que essa distinção não deve ser vista como dois tipos de contexto, mas como descrições ou construções diferentes de um mesmo evento ou situação.

O autor afirma que o pressuposto fundamental da teoria que ele propõe é que os fatores e situações sociais que têm sido considerados ou nomeados contexto, descritos em estudos anteriores, "não podem, eventualmente, ter uma relação direta sobre a fala ou sobre o texto como um todo e, portanto, não devem ser chamados 'contexto', em primeiro lugar." (VAN DIJK, 2007, p. 288) ${ }^{39}$. Pois, ao assumir que é a situação social (local ou global) que influencia diretamente a fala ou o texto, teríamos o mesmo discurso sempre que houvesse a mesma situação social. Mas o que ocorre é exatamente o contrário: é a interpretação dos participantes, sobre uma determinada situação social que influencia na sua produção ou compreensão de um texto. Uma vez que em uma mesma situação comunicativa os participantes podem interpretar os aspectos daquela situação social de maneiras diferentes,

\footnotetext{
${ }^{37}$ Bruno (2004, p.107) toma de Schacter (1994, p. 38) a seguinte afirmação: “O aprendiz infere o domínio dentro do universo do qual a solução para o corrente problema de língua será exigida, partindo de seu conhecimento prévio. Então, o aprendiz prova as hipóteses daquele domínio."

38 "the concept of 'context' plays a controversial role in the study of discourse, conversation and interaction in general." (VAN DIJK, 2007, p.282).

39 "cannot possibly have a direct influence on talk or text at all and therefore should not be called 'context' in the first place." (VAN DIJK, 2007, p.288).
} 
em conformidade com seu objetivo pessoal, pode-se considerar que contextos são, por definição, subjetivos.

Por conseguinte, sendo um conceito subjetivo, o que é socialmente relevante para um participante em um determinado momento pode não ser para o outro participante ou alterase para o mesmo participante em outro momento. E com isso, van Dijk (2012) aponta outro aspecto fundamental desta teoria: a relatividade do contexto com relação à relevância.

Considerando a subjetividade do processo de entendimento/interpretação, o autor adota a noção de modelo mental como a mais satisfatória para suas análises, enfatizando que participantes de uma situação comunicativa constroem dinamicamente um modelo mental da conversa em curso, de acordo com a relevância daquela situação social. Dessa forma, entender o que está sendo dito em uma conversação demanda a construção de dois tipos de modelos: um modelo mental semântico sobre o que é a conversa (referência, co-referência, coerência no texto e fala) e um modelo mental pragmático quanto a aspectos relevantes do evento comunicativo.

Desenvolvendo um pouco mais sua fundamentação, van Dijk (2012) destaca que o contexto não é uma representação mental estática, mas um modelo dinamicamente alterado, controlado ao longo da conversa em curso a cada momento. Nesse sentido, esta teoria é de contexto e, ao mesmo tempo, uma teoria de relevância, porque considera-se para a análise o que é situacionalmente relevante para cada participante, entendido relevância nos termos de Sperber \& Wilson ${ }^{40}$.

O autor desenvolve, a partir desses fundamentos, o conceito de modelo de contexto. Modelos de contexto estão relacionados de maneira geral a representações sociais compartilhadas com outros membros do mesmo grupo social ou comunidade. Assim, "modelos mentais de contextos são subjetivos, mas não arbitrários" (VAN DIJK, 2012, p.293), pois, a experiência dos participantes, nas milhares de situações de comunicação, Ihes permite generalizar e normalizar tais situações. A partir dessas experiências, os usuários da língua constroem modelos mentais generalizados para compartilhar representações sociais de tais situações.

Crucial, neste caso, é a representação mútua que os participantes têm uns do conhecimento dos outros, uma condição fundamental para qualquer interação. $\mathrm{O}$ autor postula, portanto, que nos modelos de contexto há um dispositivo de conhecimento - o dispositivo-K, por meio do qual a cada momento da interação os participantes avaliam o que já sabem. "Em cada ponto na conversa, um orador precisa 'calcular' o que o destinatário já sabe, e aproveitar este

\footnotetext{
${ }^{40}$ Van Dijk (2007) usa a versão de Sperber \& Wilson em inglês: Relevance: Communication and Cognition. Cambridge, MA: Blackwell, 1995.
} 
meta-conhecimento na produção do próximo fragmento de discurso." (VAN DIJK, 2007, p. $296)^{41}$. Essa afirmação reforça a característica essencial desta teoria: o fator cognitivo.

Podemos destacar que, para van Dijk (2007, 2012), contextos

- são fruto de interpretações subjetivas dos participantes de situações interacionais ou comunicativas, aliando experiências individuais e bases sociais "compartilhadas de uma comunidade discursiva (conhecimentos, atitudes, ideologias, gramática, regras, normas e valores)" (VAN DIJK, 2012, p. 36);

- são dinâmicos, visto que, como modelos mentais, vão se construindo de acordo com as experiências vividas pelos participantes, sejam anteriores à situação comunicativa, seja durante o processo em que se desenrola a situação;

- "os contextos não representam situações sociais ou comunicativas completas, mas somente aquelas propriedades que são relevantes de passagem" (VAN DIJK, 2012, p. 39).

Concluindo, van Dijk (2007, 2012) acredita que o dinamismo na reelaboração de estratégias e interpretações dos participantes só pode ser explicado por representações mentais, utilizadas para a criação de modelos de contexto que são a interface entre as estruturas sociais e a fala. O autor reconhece que a Análise da Conversação utiliza estas noções, mas não as explicita. "Uma abordagem irracional da conversação é uma ilusão ou uma redução, nada menos do que uma teoria da mente sem uma dimensão interacional ou social." (VAN DIJK, 2007, p. $300)^{42}$. Daí ser necessário desenvolver uma teoria integrada, "à luz de uma abordagem sociocognitiva mais sofisticada, que combina análise interacional, discursiva e cognitiva" (VAN DIJK, 2007, p.312) ${ }^{43}$.

\subsection{O que entendemos por contexto}

Parret (1985), Ibañez (1990) e van Dijk (2007, 2012) analisam e percebem o contexto sob o ponto de vista de sua natureza complexa, implicada com o texto, em sua dimensão dialógica. Apontam, assim, para a inter-relação existente entre o processo cognitivo e o processo discursivo que constitui o contexto. Tais processos estão influenciados pelas representações dos participantes e, por essa razão estamos de acordo com Maingueneau (1997, p.28), quando afirma que "O contexto não é um dispositivo que um observador exterior possa apreender".

Parret (1985) considera a interação um elemento fundamental do processo dialógico criticando as teorias linguísticas que têm seu foco no ponto de vista do falante. Ele postula uma tipologia de contextualizações, sendo estas componentes do contexto e, de certa forma,

\footnotetext{
41 "At each point in talk a speaker needs to 'calculate' what the recipients already know, and take this metaknowledge into account in the production of the next discourse fragment." (VAN DIJK, 2007, p.296).

42 "A mindless approach to conversation is an illusion or a reduction, no less than a theory of mind without an interactional or social dimension." (VAN DIJK, 2007, p.300).

43 "in the light of a more sophisticated sociocognitive approach that combines interactional, discursive and cognitive analysis." (VAN DIJK, 2007, p.312).
} 
atribui a este tal importância que parece desconsiderar outros fatores que interferem na compreensão, como se a contextualização pudesse dar conta da ambiguidade e como se o falante tivesse controle sobre o processo.

Ibañez (1990) elabora sua proposta teórica com base na criação subjetiva e individual do contexto. Este constituído por uma construção situacional, fruto da seleção de elementos da realidade, relevantes naquele dado instante, para aquele participante, e por um contexto cultural, composto pelas regras e convenções sociais da comunidade da qual aquele participante faz parte. Ibañez (1990) se aproxima de van Dijk (2007) ao entender que a elaboração do contexto é uma construção mental.

Van Dijk $(2007,2012)$ baseia sua teoria de contexto em modelos mentais: um modelo mental semântico relacionado a elementos linguísticos e um modelo mental pragmático relacionado a experiências individuais e sociais dos interlocutores. Atribui à interpretação dos participantes sobre uma determinada situação social o fator primordial de influência na produção ou compreensão de um texto. Sendo a interpretação um processo subjetivo, o autor defende uma teoria baseada em modelos mentais de contexto. O contexto, por sua vez se reelabora no instante mesmo da produção, por meio de um dispositivo de conhecimento, que ele denominou 'dispositivo-K'. Este mecanismo mental permite ao participante ir adaptando seu discurso num processo de retroalimentação de conhecimentos, selecionados conforme sua relevância para aquela situação. Neste sentido, a teoria proposta por van Dijk $(2007,2012)$ dialoga com a Teoria da Relevância de Sperber \& Wilson (1994).

Essencialmente, a partir dos pressupostos teóricos e reflexões de Parret (1985), Ibañez (1990) e van Dijk (2007, 2012), entendemos contexto como uma construção mental elaborada pelos interlocutores em um processo recursivo e retroativo, que se dá a partir da combinação de fatores verbais (elementos linguísticos) e não verbais (conhecimentos prévios, compartilhados ou não) presentes em uma situação social específica que os participantes inconscientemente selecionam, de acordo com a relevância que tenham para aquela situação, para a sua compreensão e produção discursiva, em decorrência de sua compreensão sobre a situação comunicativa.

Para fechar a subseção Compreensão e Contexto, apresentamos um esquema para melhor visualização sobre o que entendemos por contexto e, na sequência, daremos continuidade ao desenvolvimento do referencial teórico. 


\section{Quadro 3 - Componentes do contexto}

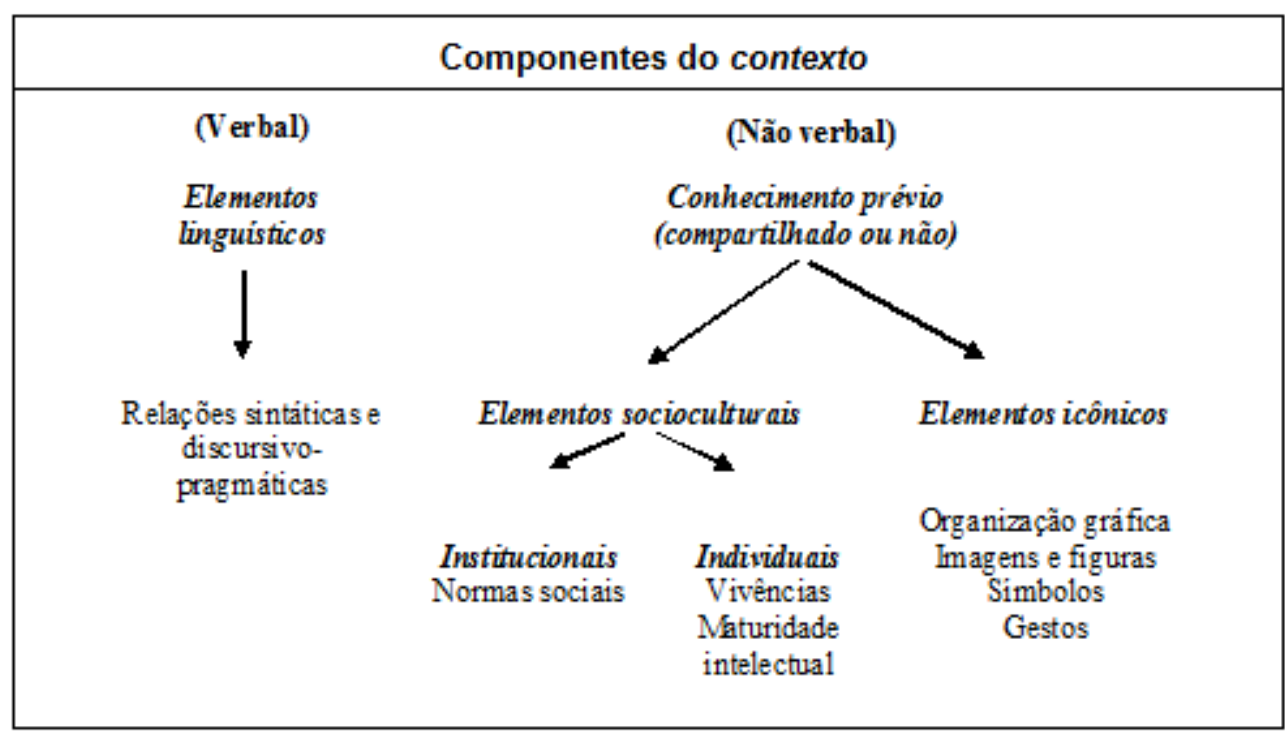

Fonte: Elaborado pela autora

\subsubsection{Recursos argumentativos}

Nesse movimento de construção colaborativa, interacional, o falante para ser bem interpretado faz escolhas, conscientes ou não, que consideram "certas hipóteses concernentes à interpretação e às reações do ouvinte", afirma Kerbrat-Orecchioni (1995, p. 25) citada por Hilgert (2008, p.127). Portanto, pode-se considerar ambos como sujeitos da enunciação e da compreensão, considerando que tanto enunciador quanto enunciatário se empenham na busca da compreensão.

Porém, ainda que partilhem de uma mesma língua, de uma mesma cultura, Hilgert (2008) alerta para o risco de problemas de compreensão, pelo simples fato de estarem interagindo pessoas diferentes, que ocupam lugares diferentes na relação.

Relações interpessoais envolvendo sujeitos diferentes em posições diferentes demandam estratégias para a manutenção de uma relação harmoniosa. Nesse sentido, a cortesia tem um papel fundamental e se manifesta, prevalentemente por ato linguístico, visto que as relações humanas, como destaca Hilgert (2008, p. 134), "em sua maioria, se realizam linguisticamente, ou ao menos vêm acompanhadas de atos linguísticos".

No caso dos enunciados utilizados em nossos testes-piloto, a introdução pela partícula " $Y / E$ " e a forma interrogativa, nos permitem supor tratar-se de procedimentos linguísticos com objetivos argumentativos. Assim, nesta seção, apresentaremos estudos e concepções teóricas de alguns recursos e estratégias argumentativas com ênfase em operadores argumentativos (PORTOLÉS, 1988; KOCH, 2011) e marcas de cortesia e/ou atenuação (BRIZ, 2013). 


\subsection{Operadores argumentativos}

Em ambas as tirinhas, o enunciado em destaque não apresenta uma Oração Condicional prototípica, conforme já evidenciamos:

(10) ¿Y si jugamos a otra cosa?

(11) ¿Y si pintamos una bailarina?

Castilho (2014) afirma que a partícula $E$, do português, no início de enunciados, preserva seu valor latino original de adicionador de atos de fala (p. 350) e cita a opinião de Scorretti (1988, p. 234) que considera que essa partícula, no início de sentença parece ser sintaticamente inativa e apresenta como exemplo: E se eu não o encontro?. Castilho (2014) contrapõe essa ideia argumentando que o $E$ é sintaticamente ativo, pois, há um discurso preexistente ao enunciado introduzido pela partícula.

Da mesma forma, considerando um discurso preexistente, Escandell Vidal (1999, p.3955) aponta como uma função para a partícula $Y$ apresentar "un nuevo supuesto que el emisor somete a la consideración del destinatario".

Nos enunciados em questão, podemos entender que a partícula $Y$ (elemento linguístico) articula os elementos não linguísticos do contexto em cada uma das situações sociais (brincadeira de criança) dos personagens:

(10) situação de perigo por estarem desarmados, frente a um ataque de piratas

(11) discussão em busca de um tema para a nova pintura

a uma nova proposição a seu interlocutor:

(10) mudar de brincadeira

(11) pintar uma bailarina

A conjunção Si remete a uma construção de hipótese e a introdução do enunciado pela partícula $Y$ permite-nos entender que seu papel é o de ampliar a força argumentativa que ambos teriam, em separado. A junção [ $Y$ si / E se] pode ser considerada um operador argumentativo analisado à luz da Teoria da Argumentação.

De acordo com Portolés (1988, p. 80),

Un conector argumentativo consiste en una unidad que articula dos miembros del discurso, o más, que intervienen en una estrategia argumentativa única ( $v$. gr. pero, sin embargo, además, etc.), y un operador argumentativo es una unidad que, aplicada a un contenido, transforma las potencialidades argumentativas de este contenido (v. gr. bien, casi, un poco, etc.). (grifos nossos)

Segundo Koch (2011), considerando que o enunciado orienta o discurso ao determinar os encadeamentos possíveis com outros enunciados, de forma a continuá-lo, pode-se admitir que há enunciados que são empregados para orientar o interlocutor na direção de certos tipos 
de conclusão em detrimento de outros. A gramática identifica uma série de morfemas como responsáveis por esses encadeamentos - os conectivos.

Portolés (1988) afirma que os conectores carregam em si uma carga semântica que constrói o sentido dos enunciados em que se encontram e se distinguem entre conectores que mantém a orientação argumentativa (además, así pues, por tanto, entonces) e conectores que alteram a orientação argumentativa (sin embargo, no obstante, por el contrario, antes bien, ahora bien) de enunciados. O autor dá como exemplo: "Este chico está gordo. Sin embargo, no quiere adelgazar." O conector sin embargo "vincula el primer enunciado con el segundo e indica por su significación que, contrariamente a lo que se debería esperar de la orientación argumentativa de este chico está gordo, el muchacho no quiere adelgazar."(PORTOLÉS, 1988, p. 78-79).

A conjunção $Y$ interpretada enquanto conector argumentativo tem, na maioria das vezes, a função de vincular dois elementos do discurso, como coordenativa. No entanto, da forma como se apresenta nos enunciados que estamos analisando, deixa de ter a função de coordenação, no sentido lato, e adquire força argumentativa alterando a orientação argumentativa da conjunção $S /$ que, prototipicamente seria de condição. Neste caso, nos termos de Portolés (1988), a partícula $Y$ passaria à função de operador argumentativo.

Portolés (1988, p.80) ressalta a importância de diferenciar conectores de operadores argumentativos. E afirma que todos os conectores são um tipo de marcadores do discurso ${ }^{44}$, mas a maioria dos operadores argumentativos não o são, visto estarem integrados gramaticalmente ao sintagma em que aparecem, como no exemplo:

Así, un adjetivo como mero varía la potencialidad argumentativa de su enunciado. Por ejemplo, de:

(13) Ha sido un accidente.

Se puede proseguir el discurso:

(14) a. Se pueden pedir responsabilidades.

b. No se pueden pedir responsabilidades.

Mientras que de:

(15) Ha sido un mero accidente,

difícilmente se seguiría con (14a). El adjetivo mero limita las posibles continuaciones del discurso a partir de ha sido un accidente, actúa, pues, como un operador argumentativo. Sin embargo, no es un marcador del discurso, ya que carece de fijación morfológica -tiene flexión de género y número-y de la independencia sintáctica -forma constituyente de accidentepropia de estos elementos.

\footnotetext{
${ }^{44} \mathrm{Cf}$. Portolés (1988) marcadores do discurso pertencem a uma determinada categoria gramatical o que restringe seu uso a determinadas construções. O autor esclarece que o termo "marcador do discurso" não pertence à Teoria da Argumentação, na qual se baseia o texto. Mas sua utilização se dá no sentido genérico, conforme concebido no livro que integra.
} 
Fica claro, então, que a orientação argumentativa não está somente na sintaxe, mas na semântica e, por que não, também nos diferentes elementos que compõem o contexto. Portanto, nos termos de Portolés (1988), podemos considerar a junção dos conectores $Y+S I$, presente nos enunciados (10) e (11) como um operador argumentativo, porque estabelece uma determinada orientação argumentativa.

Nesta discussão, incluímos Koch (2011) por apresentar um questionamento para as classificações dadas, nas gramáticas, aos conectores e conjunções tratados como operadores relacionais. Na opinião da autora, estes constituem operadores argumentativos ou discursivos. Koch (2011) defende a macrossintaxe do discurso (ou semântica argumentativa) porque considera que são esses elementos que determinam o valor argumentativo dos enunciados. São marcas linguísticas importantes da enunciação.

Esses operadores formulam diversos paradigmas. É essa relação paradigmática que vai determinar a que classe argumentativa o enunciado pertence. Já que todos os operadores fazem parte da gramática, é evidente que essas instruções, codificadas, de natureza gramatical, supõem evidentemente um valor retórico da construção, ou seja, um valor retórico ou argumentativo - da própria gramática. $O$ fato de se admitir a existência de relações retóricas ou argumentativas inscritas na própria língua é que leva a postular a argumentação como o ato linguístico fundamental. (KOCH, 2011, p.106)

Considerar " $Y$ si" como operador argumentativo nos dá sustentação para afirmar que os enunciados (10) e (11) não são Orações Condicionais sem apódose, nem pseudocondicionais ou mesmo orações hipotéticas. Por quê, então, não analisar estes enunciados do ponto de vista de uma estratégia argumentativa?

Koch (2011) acredita, e estamos de acordo com ela, que conscientizar os usuários da língua do valor argumentativo dessas marcas lhes possibilita percebê-las no discurso do outro e utilizá-las, com eficácia, no seu próprio. Para além do viés discursivo-pragmático, essa observação nos leva novamente ao questionamento que vimos apresentando com relação ao tratamento dado, em alguns casos, a esses conteúdos na instrução formal que, normalmente, reproduz classificações gramaticais sem reflexão.

\subsection{Cortesia e atenuação}

A partir das discussões apresentadas no item anterior, concluímos que a locução conjuntiva $Y$ si / E se constitui um operador argumentativo que altera a orientação argumentativa criando um efeito de sentido de proposição ou de sugestão. Aliado à forma interrogativa com que se apresentam os enunciados (10) e (11), identificamos que se trataria, por outro lado, de uma estratégia argumentativa que visa à cortesia como uma maneira de atenuar alternativas assertivas. Vejamos nosso argumento. 
Charaudeau e Maingueneau $(2016$, p383) destacam os atos de linguagem indiretos como "o caso mais espetacular" de formulação determinada pela polidez, e explicam:

Por que nos preocupamos em formular enunciados como "Você poderia fechar a janela?", se "Feche a janela" diz a mesma coisa, e de forma mais simples e clara? É que, tendo ares menos coercitivos, a formulação indireta brutaliza menos a face do destinatário: o custo cognitivo suplementar (para o codificador e para o decodificador) é amplamente compensado pelo benefício psicológico usufruído por ambos.

Considerando que nas tirinhas, os enunciados apresentam uma proposição ou sugestão para uma nova brincadeira (10) e um tema para a pintura (11), os enunciadores (Boris e Batu, respectivamente) utilizam uma forma atenuadora em busca de adesão à sua ideia.

Segundo Briz (2013, p. 284) a atenuação é o lado linguístico da manifestação de cortesia.

A atenuação é uma categoria pragmática, um mecanismo estratégico e tático (portanto, intencional), que se relaciona à efetividade e à eficácia do discurso, ao alcance dos objetivos na interação, além de se tratar de uma função só determinável a partir do contexto.

É o contexto, nos termos de van Dijk (2007, 2012), que fornece, ao enunciador, elementos para a elaboração mental da situação comunicativa, bem como da receptividade de seu interlocutor, a fim de produzir o efeito de sentido que viabiliza atingir seu objetivo discursivo.

\subsubsection{O Pensamento Complexo como campo de conhecimento para uma reflexão sobre a instrução formal}

À luz do Pensamento Complexo, com base em Edgar Morin (2003, 2006), destacamos o princípio sistêmico-organizacional. Do ponto de vista sistêmico-organizacional o todo não pode ser definido pela soma das partes. Morin (2003) defende que as partes possuem qualidades próprias, mas que sofrem influências por fazerem parte do todo. Da mesma forma, em um movimento de retroação e recursividade, o todo é afetado pelas ações e interações entre as partes que se organizam entre a ordem e a desordem. O princípio se compõe de um movimento dinâmico de auto-produção e auto-organização.

Neste sentido, podemos interpretar que a escola é formada por uma multiplicidade organizacional constituída pelo professor, pelo aluno e pelo processo de ensino e aprendizagem (dentre outros componentes), que, por sua vez, dependem desta (auto)organização (muitas vezes aleatória), enquanto constituintes da própria escola.

Encontramos em Fiedler-Ferrara (2003, p. 72) uma colocação que reflete nossa preocupação e reforça nossa proposta:

Em educação, há de se reconhecer e reafirmar o pioneirismo do pensar já complexista de Piaget. Mais recentemente, alguns autores têm se preocupado em construir metodologias e curricula que possibilitem a 
transição de um pensamento simples para um complexo. Busca-se, dessa forma, uma perspectiva sistêmica do mundo, que permita superar visões baseadas em causalidade estrita e linear, muitas vezes presentes na práxis escolar e nos livros didáticos, e que responda à necessidade de superação do processo de fragmentação do conhecimento. Interdisciplinaridade, nesse contexto, passa a ter, no processo de aprendizagem, um significado mais preciso. Em particular, a seleção e a organização de conteúdos escolares a partir de uma perspectiva sistêmica-complexista torna-se essencial e têm sido tratada por alguns autores.

Tomando por exemplo a complexa estrutura dos enunciados que utilizamos nos testes e das próprias Orações Condicionais, defendemos uma mudança de paradigma quanto à organização linear de determinados conteúdos curriculares. A segmentação e a fragmentação destes, principalmente quando se trata de aquisição/aprendizagem e ensino de uma língua estrangeira, em especial de E-LE, deixa lacunas importantes que, certamente, comprometem o processo ${ }^{45}$ dos alunos.

Considerando a complexidade dos elementos envolvidos em um ambiente de instrução formal, bem como a dinamicidade do processo de aquisição, aprendizagem e ensino de uma LE, nossa pesquisa, com relação a este campo de estudo, se pauta pelos princípios do Pensamento Complexo, de Edgar Morin $(2003,2006)$, o qual acreditamos ofereça o suporte necessário para uma proposta de revisão na forma como tratamos estes e, por que não dizer, outros conteúdos, em aula.

A tradição do pensamento que forma o ideário das escolas elementares ordena que se reduza o complexo ao simples, que se separe o que está ligado, que se unifique o que é múltiplo, que se elimine tudo aquilo que traz desordens ou contradições para nosso entendimento. $O$ pensamento que recorta e isola [...] projeta sobre a sociedade e as relações humanas as restrições e os mecanismos inumanos da máquina artificial com sua visão determinista, mecanicista, quantitativa, formalista, que ignora, oculta e dissolve tudo o que é subjetivo, afetivo, livre e criador. (MORIN, 2009, p.18)

Nas palavras de Morin (2009) temos a confirmação de uma prática que observamos no ambiente de educação formal - a organização de conteúdos de forma fragmentada e desconectada, que, especificamente no ensino de línguas, recorrentemente, enfatiza o ensino de regras gramaticais descoladas do discurso.

Segundo Possenti (2009), haveria uma separação entre o que é gramática e o que é discurso originada pela concepção de linguagem de Jakobson, na qual o falante organiza sintaxe, semântica, pragmática e discurso em camadas, nessa ordem. Essa forma de estabelecer a

\footnotetext{
${ }^{45}$ Cf. Bruno (2006, p. 152) o processo em direção à língua-alvo é mediado pela produção e compreensão, que funcionam em simetria e assimetria.
} 
linguagem teria reflexos na interpretação ${ }^{46}$. Ou seja, também realizada em camadas de forma que só se apela para a próxima camada quando a anterior foi insuficiente.

Também em oposição a essa dissociação, Koch (2011, p. 19) entende a pragmática como um nível intermediário entre o sintático e o semântico, e considera os três níveis como "indissoluvelmente interligados". Em nossa forma de ver, os enunciados que ora analisamos refletem essa proposição e, por essa razão, entendemos que o ensino deve-se desenvolver de forma dialógica ${ }^{47}$ a fim de permitir ao aprendiz explorar as incontáveis possiblidades pragmáticas que a língua oferece ao falante, durante o processo de aquisição de LE.

A análise dos dados obtidos nos permitirá verificar se há influência da instrução formal para a compreensão dos enunciados utilizados nesta pesquisa.

\subsubsection{Para fechar este capítulo}

Salientamos que ao apresentar as análises dos dados, no Capítulo 3, usamos outros aportes, de outros autores, com o propósito de melhor elucidarmos os enunciados utilizados nos testes. Tais aportes não fazem parte desta descrição porque as considerações usadas são de ordem pontual.

\footnotetext{
${ }^{46}$ Bruno (2006, p.16) apresenta uma reflexão relacionada a essa forma de organizar a interpretação, inclusive revendo o uso da teoria de aquisição de Schachter (1994), na qual a noção de "domínios" considera apenas o conhecimento sintático do aprendiz para a elaboração de hipóteses.

${ }^{47}$ Cf. Morin (2003, p. 36) "o princípio dialógico pode ser definido como associação complexa (complementar, concorrente, antagônica) de instâncias necessárias, conjuntamente necessárias à existência, ao funcionamento e ao desenvolvimento de um fenômeno organizado".
} 


\section{CAPÍTULO 2 \\ Caminhos da pesquisa: Metodologia e análise das tirinhas}

"Digo: o real não está na saída nem na chegada: ele se dispõe para a gente é no meio da travessia."

(Guimarães Rosa,2001, p. 80)

\subsection{Introdução}

Neste capítulo, apresentamos uma descrição do local e a caracterização dos sujeitos de pesquisa, a metodologia utilizada para a composição do corpus e possibilidades de análise, a partir dos nossos estudos.

\subsection{Local e sujeitos da pesquisa}

Conforme mencionamos anteriormente, nossa proposta para o desenvolvimento deste trabalho teve como motivação um desdobramento dos resultados obtidos na pesquisa realizada na IC. Naquela, contamos com a colaboração de licenciandos de diferentes períodos do Curso de Letras-Espanhol, do qual participávamos como licencianda também. Ou seja, nem todos os informantes em questão, naquela oportunidade, haviam tido contato com o conteúdo que estávamos analisando - as Orações Condicionais.

Para a composição do corpus que elaboramos para este trabalho, contamos com as respostas de 41 informantes aprendizes iniciantes de E-LE: 30 alunos do Ensino Médio, de uma escola pública estadual, do município de Alfenas, Minas Gerais, com idades entre e 15 e 18 anos e 11 estudantes de pós-graduação, de diversas áreas, alunos de E-LE do projeto Idiomas sem Fronteiras (IsF), da Universidade Federal de Alfenas - UNIFAL-MG, com idades entre 19 e 48 anos.

A escolha desse perfil de informantes teve como motivação a busca por alunos de E-LE, nativos de $P B$, que não fossem discentes de Letras-Espanhol. Desta forma, privilegiamos futuros usuários de Espanhol que não refletem, necessariamente, sobre a língua como objeto de ensino. $O$ contato com os sujeitos estudantes de pós-graduação foi facilitado pela professora responsável pelas aulas em um curso de E-LE, integrante do IsF, na UNIFAL-MG, onde atuo como servidora, na Pró-Reitoria de Extensão, como Técnico em Assuntos Educacionais. Aos jovens alunos de Ensino Médio, nosso acesso foi facilitado pela professora regente de E-LE, na Escola Estadual Dr. Emílio da Silveira, uma companheira do Curso de Letras-Espanhol daquela universidade.

A maioria dos sujeitos não havia estudado, formalmente, o conteúdo gramatical que inclui as Orações Condicionais. Este, também, foi outro fator importante na escolha dos sujeitos, visto que buscávamos verificar se a instrução formal teria (ou não) influência sobre a compreensão, considerando os resultados obtidos por Bruno (2006), mencionados anteriormente. 


\subsection{Metodologia de pesquisa}

Descrevemos, nesta seção, a organização dos informantes e a forma de identificação, além das atividades das quais eles participaram e cujas respostas constituem nosso corpus.

\subsubsection{A identificação dos sujeitos de pesquisa}

Os sujeitos de pesquisa foram organizados, aleatoriamente, em dois grupos, nomeados como G1 (grupo 1) e G2 (grupo 2), conforme a Tirinha com a qual trabalharam - Tirinha1 e Tirinha 2 , respectivamente.

O Grupo 1 foi composto por 17 alunos do Ensino Médio ${ }^{48}$ e 5 universitários, estudantes de pós-graduação das áreas de Farmácia, Fisioterapia, História e Letras. O Grupo 2 contou com a colaboração de 13 alunos do Ensino Médio e 6 estudantes de pós-graduação das áreas de Biomedicina, Enfermagem, Farmácia, Medicina e Pedagogia. Dentre eles, um servidor administrativo da Universidade.

Para cada participante foi atribuído um número, de forma sequencial e aleatória, a fim de preservar sua identidade. Incluímos, também, no código do informante, uma identificação da categoria à qual este pertence - EM-Ensino Médio ou UN-Universitário, a fim de facilitar a observação relativa à influência da idade ou maturidade intelectual nas repostas dadas.

Desta forma, G1-EM-007 identifica o informante número 7, aluno do Ensino Médio, do grupo 1; G2-UN-004, identifica o participante número 4, estudante universitário, do grupo 2, e, assim, sucessivamente.

\subsubsection{A composição do corpus}

Conforme citado anteriormente, os enunciados utilizados nas atividades propostas aos sujeitos foram destacados de duas tirinhas de Tute - Juan Matías Loiseau, escritor argentino, que nos apresenta Batu, um garoto de cabelos ruivos, sempre acompanhado de seu cãozinho azul Tútum e de seu amigo Boris.

O corpus que analisaremos se constitui das respostas obtidas a partir do desenvolvimento de atividades propostas aos sujeitos, relacionadas aos enunciados em questão.

Cada grupo de participantes desenvolveu duas atividades referentes a uma das tirinhas: o Grupo 1, com a Tirinha 1 e o Grupo 2, com a Tirinha 2.

Como introdução às atividades, todos os participantes receberam a seguinte informação:

\footnotetext{
${ }^{48}$ Cabe informar que um dos sujeitos, aluno de Ensino Médio, componente do Grupo 1, apresentou respostas incompreensíveis e, por esta razão suas respostas, foram desconsideradas.
} 
As atividades estão relacionadas a uma tirinha de Tute (Juan Matías Loiseau), escritor argentino, que nos apresenta alguns personagens: Batu, um garoto de cabelos ruivos, sempre acompanhado de seu cãozinho azul, Tútum e de seu amigo Boris (garoto com óculos).

Na sequência, acompanhadas pela imagem da tirinha correspondente, foram apresentadas as atividades de cada teste.

Os sujeitos componentes do Grupo 1 receberam as seguintes atividades, juntamente com a imagem da Tirinha 1, conforme se segue:

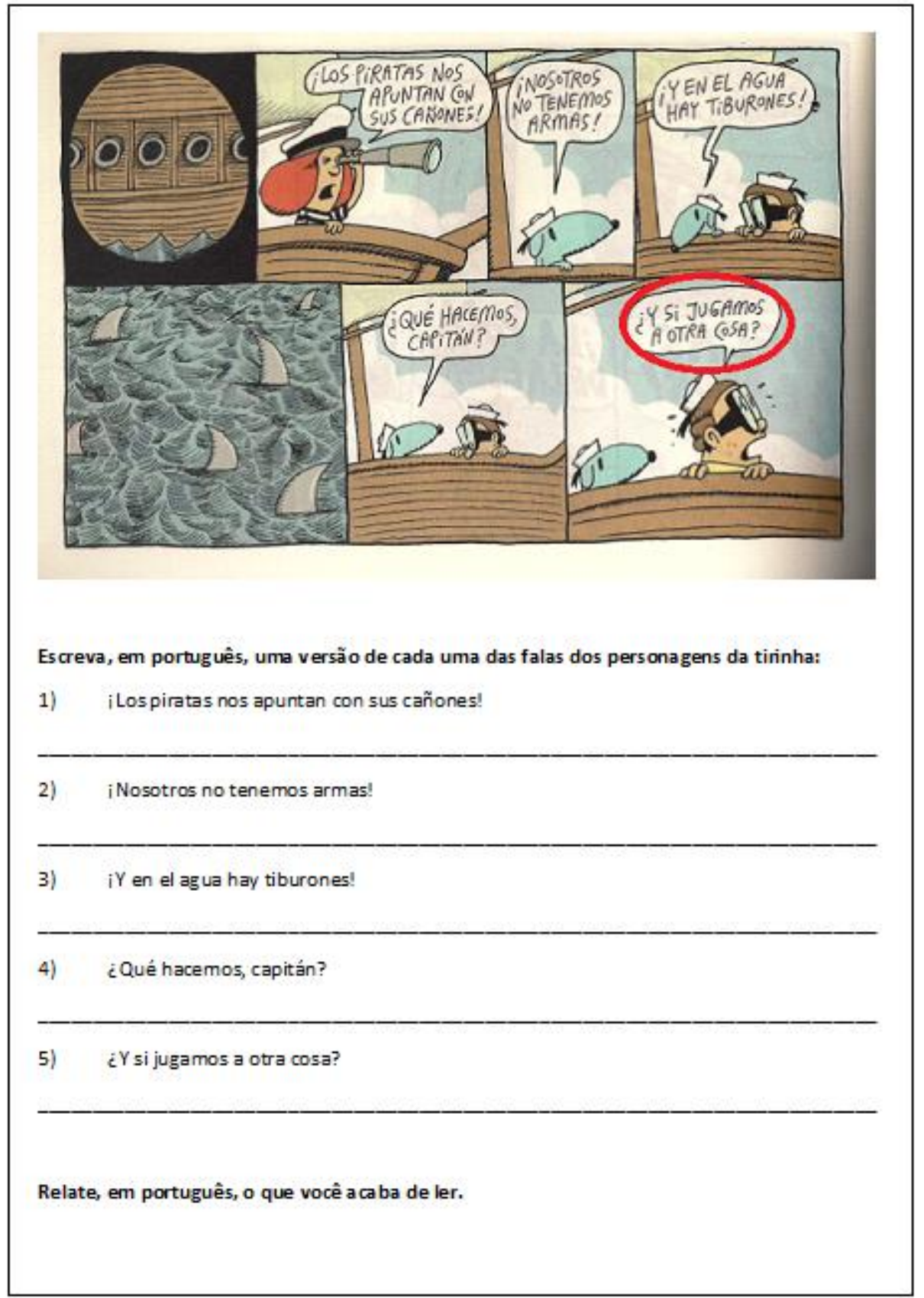


Os sujeitos componentes do Grupo 2 receberam as seguintes atividades, juntamente com a imagem da Tirinha 2, conforme se segue:

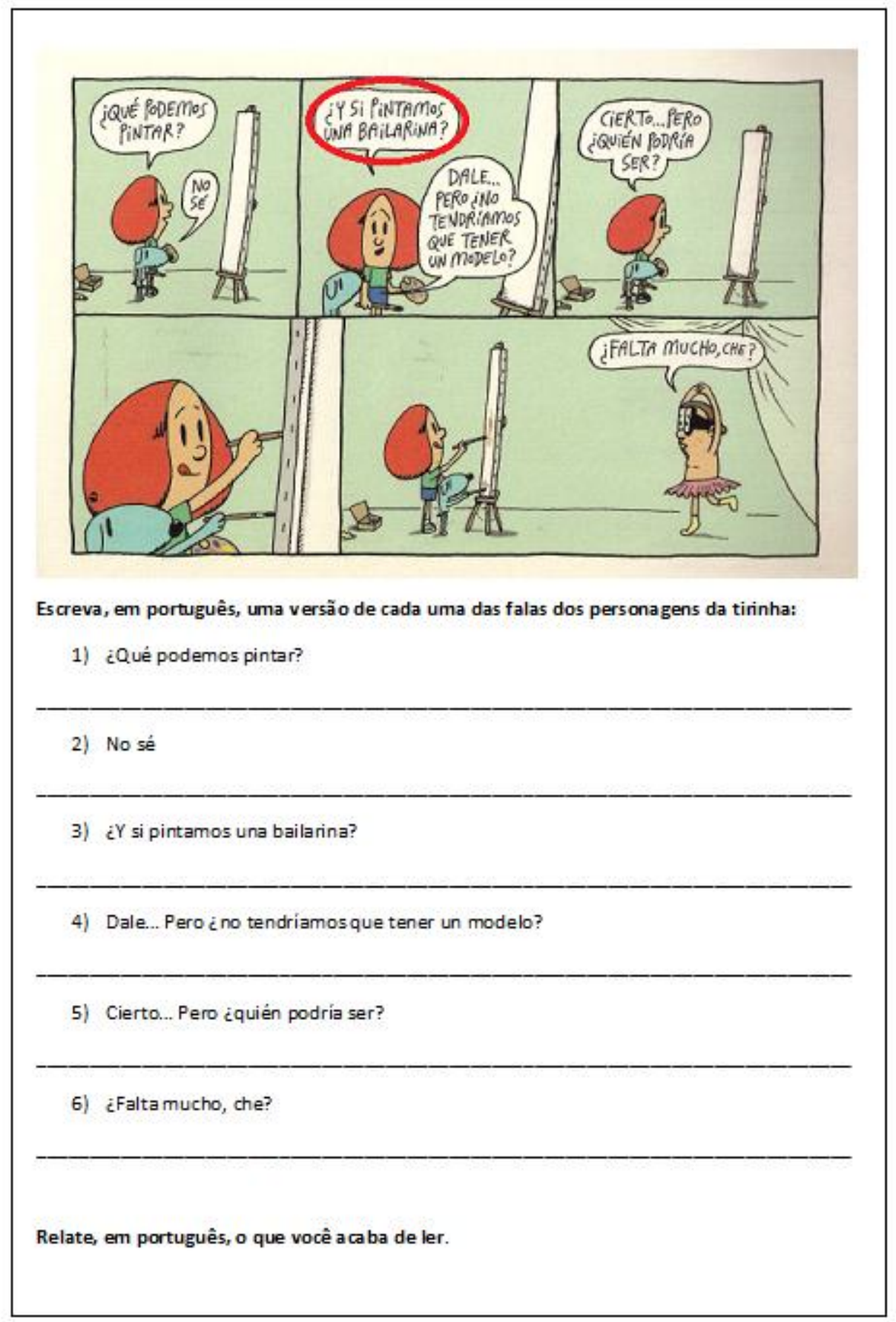

A reformulação dos enunciados, em português, referente à primeira atividade, teve por objetivo verificar qual a compreensão que o sujeito teve da situação e, de acordo com a forma ou recurso linguístico utilizado, checar se houve a influência ou não da LM ou ainda do conhecimento de outras línguas para sua elaboração. A produção de uma versão em português ou reformulação, nos termos de Maingueneau (1997, p. 86), visa à "transformação de uma unidade discursiva de tamanho variável (da palavra ao texto) numa outra que seja, de uma maneira ou de outra, considerada semanticamente "equivalente»". 
$\mathrm{Na}$ atividade 2, o relato da situação representada, em português, possibilitou evidenciar quais foram os elementos discursivo-pragmáticos que interferiram na compreensão da enunciação, influenciado (ou não) pelo contexto. Nos termos de Parret (1985), a compreensão "cria" seu contexto e o contexto influencia na compreensão.

Cada uma das atividades do teste foi apresentada aos participantes sequencial e separadamente, com o objetivo de minimizar qualquer influência sobre cada uma das propostas de exercício. Ou seja, o participante teve acesso a uma atividade por vez, sendo-lhe entregue a segunda atividade somente após ter respondido à primeira. Desta forma, evitamos que o informante, tendo conhecimento da próxima atividade, sofresse alguma influência em suas respostas ou as alterasse. Buscamos, com isso, obter as respostas mais imediatas, sem possibilidade de uma revisão, diante da atividade seguinte.

\subsection{Uma análise possível}

Nesta seção, a partir de reflexões embasadas nos pressupostos teóricos que apresentamos incialmente, apresentamos uma possibilidade de interpretação, com base na qual realizamos as análises dos dados de pesquisa, obtidos por meio das atividades de reformulação das falas componentes de cada uma das tirinhas e a produção de um relato da situação representada, conforme explicitado na seção anterior.

\subsubsection{Sobre a Tirinha 1}

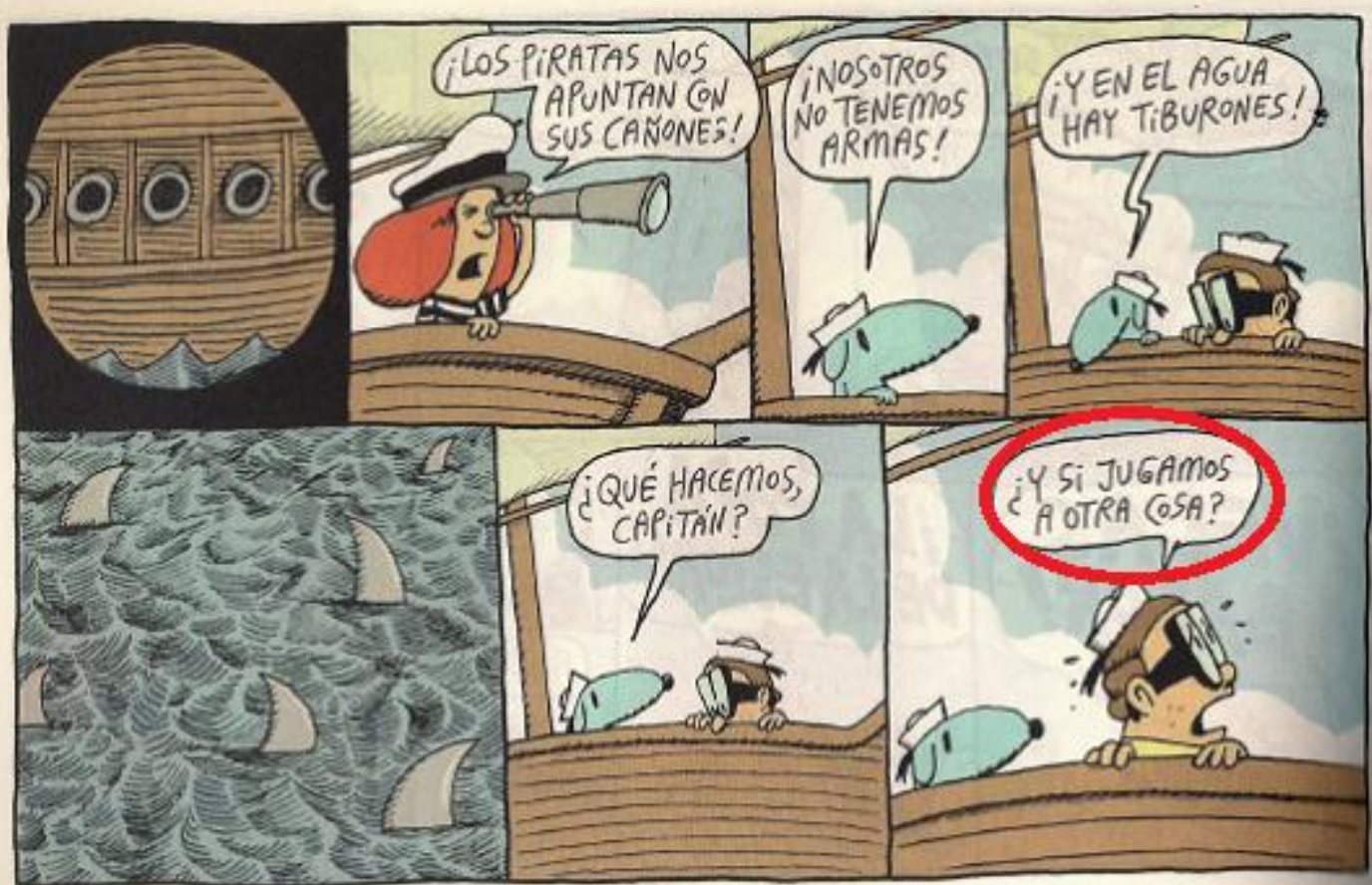

TUTE. Batu. Buenos Aires: Sudamericana, 2009 


\subsubsection{Um breve relato}

Os personagens estão em meio a uma brincadeira imaginativa, na qual se encontram em situação de perigo: em alto mar, cercados por tubarões, lutando contra piratas armados com canhões e sem armas. Esta situação é apresentada por meio da fala do capitão Batu, no segundo quadrinho que, com sua luneta, avista os canhões apontados em sua direção, conforme a imagem que aparece no primeiro quadrinho. Quem complementa a descrição dessa situação é o marinheiro Tútum, nos quadrinhos três e quatro, bem como a imagem de tubarões na água, no quinto quadrinho. A seguir, no quadrinho seis, Tútum pergunta ao capitão Batu o que vão fazer e o marinheiro Boris, que até este momento permanecia imóvel, somente olhando para a água, se manifesta no último quadrinho e, assustado, interfere: ¿Y si jugamos a otra cosa?

\subsubsection{Componentes do contexto}

Com base no esquema que apresentamos no Quadro 3: Componentes do contexto, destacamos a importância dos elementos não verbais para a compreensão da situação "contexto situacional", nos termos de Parret (1984) ou "situação comunicativa", nos termos de van Dijk (2012).

Os quadrinhos 1 e 5, sem apresentar falas, dão ideia do perigo que os personagens estão enfrentando: canhões e a água infestada de tubarões. Sabemos que Batu está no papel de capitão e Tútum e Boris são os marinheiros pelos quepes que usam. Esta condição determina que há uma hierarquia entre eles. É por isso que Tútum, no sexto quadrinho, consulta o capitão sobre o que fazer, ainda que, na imagem, pareça que ele está se dirigindo a Boris, por estar voltado em sua direção. Na verdade, quem está à direita deles, é o capitão Batu. Isto se confirma quando Boris, no último quadrinho, olha para a mesma direção que Tútum está olhando e sugere mudar de brincadeira.

A hierarquia marcada pelos quepes é um conceito construído socialmente - contexto psicológico, de Parret (1984) ou modelo mental pragmático, de van Dijk (2012) - porque envolve um conhecimento de mundo e cultural. Não identificar esta situação de hierarquia não compromete a compreensão da situação global, apresentada pela tirinha. No entanto, pode interferir na compreensão do efeito de sentido de sugestão como forma de cortesia ou atenuação. É possível afirmar que os quepes dos personagens (elemento icônico) identificando seus papéis (elemento sociocultural) permitam compreender que a pergunta (elemento linguístico) é uma forma de sugestão e cortesia, visto ser um marinheiro dirigindose a seu capitão.

\subsubsection{Nossa análise}

Diante da situação de perigo, percebe-se que Boris está apreensivo e não parece estar se divertindo. Ele transparece preocupação e medo. Assim, é possível afirmar que, apesar de formular um enunciado na forma interrogativa, ele não quer uma resposta. Trata-se de uma forma retórica de propor uma mudança na situação que o incomoda, conforme encontramos 
em Escandell Vidal (1999, p. 3955). O que Boris deseja é ver-se livre dessa situação e, para tal, podemos interpretar sua manifestação como uma sugestão para mudar de brincadeira ${ }^{49}$.

A construção escolhida por Boris - forma interrogativa, introduzida pela partícula $Y$ - denota uma estratégia com dois aspectos:

a) a introdução de um novo tema, uma "mudança de assunto" e

b) a solicitação de uma consideração por parte do destinatário, neste caso, Batu, para que se busque outra forma de diversão, como uma estratégia argumentativa, nos termos de Koch (2011).

Quanto à conjunção $S E$, considerando sua recorrência na introdução das Orações Condicionais prototípicas e a complexidade destas, apontada por Montolío (1999), podemos assumir que na situação apresentada, dentro do contexto criado pelo autor, esta opera para materializar uma situação irreal e imaginativa ${ }^{50}$, o que van Dijk (2007) chama de 'dispositivo K'.

Assim, entendemos que o enunciado em destaque ¿Y si jugamos a otra cosa? pode ser analisado com base em teorias que levem em conta fatores cognitivos, considerando que

diversas relações vitais estruturam o espaço mental: a mudança operada entre os participantes de uma cena, sua identidade, o tempo que é relacionado com a memória e a mudança, o espaço físico em que se situam os participantes, e que é comprimido no espaço combinado, a relação de causa-efeito entre os participantes, tanto quanto a relação parte-todo, a representação do participante, seu papel, a similaridade ou analogia que estabelecemos entre os participantes, suas propriedades, a similaridade que reúne participantes com propriedades comuns, a categoria a que pertencem os participantes, sua intencionalidade, a experiência primária, maiormente conectada com a visão (só sabemos quando vemos), a contrafactualidade, a contradição e a compreensão. (CASTILHO, 2014, p.466)

Assim, como mencionamos antes, as Orações Condicionais prototípicas não só apresentam hipóteses ou condições, mas também suposições. Estas envolvem uma elaboração mental ou

\footnotetext{
${ }^{49} \mathrm{Cf}$. o Diccionario panhispánico de dudas, em sua segunda definição para o verbo jugar(se):

2.Cuando significa 'practicar un juego o un deporte', en la lengua culta se usa como intransitivo y el nombre del juego va con artículo y precedido de la preposición a: «Jugaban AL fútbol de la mañana a la noche» (Martínez Evita [Arg. 1995]); "Mi madre no estaba, se había ido a jugar A LA canasta con las Caballero» (Mendicutti Palomo [Esp. 1991]). No es uso propio de la lengua española suprimir el artículo, algo habitual entre hablantes catalanes por influjo de su lengua regional: «Los niños juegan A fútbol en la enseñanza primaria» (Vanguardia [Esp.] 27.2.94). Con este mismo sentido, en el habla coloquial de amplias zonas de América, probablemente por calco del inglés (to play tennis, to play football, etc.), se usa a menudo como transitivo, esto es, sin que el sustantivo que denota el juego vaya precedido de preposición, además de no llevar artículo: «Es empleado bancario y juega fútbol» (Bryce Vida [Perú 1981]); «Juntaba a sus paisanos para jugar cartas» (Mastretta Vida [Méx. 1990]); es uso que, por su arraigo en el español americano, ha de considerarse válido. (RAE, 2016, grifo nosso)

${ }^{50}$ Fauconnier (1985 apud CASTILHO, 2014), no âmbito de sua Teoria dos Espaços mentais, afirma que a conjunção SE marca um espaço mental hipotético.
} 
cognitiva e conhecimentos compartilhados que o falante pode manipular buscando obter êxito em seu discurso.

Além do processo cognitivo que essa estrutura não prototípica demanda, a situação de enunciação presente no enunciado em questão, certamente apresenta muitos dos elementos identificados por Castilho (2014), principalmente a relação causa-efeito. Por essa razão, entendemos que a análise das respostas dadas pelos sujeitos, à luz da Teoria do Contexto, de van Dijk (2007), contribui para a identificação da influência do contexto na construção de sentidos e, consequentemente, para a compreensão do enunciado.

O contexto provê informações ao enunciador (tubarões na água e nenhuma arma para contraatacar os piratas) que o leva à construção mental de uma situação de perigo iminente. No entanto, a fim de preservar sua imagem e, inclusive a do amigo Batu, conforme Briz (2003), e continuar brincando, Boris apresenta uma sugestão para a troca de brincadeira, de forma cortês.

Por outro lado, é interessante observar que a combinação de $S E$, pensada como conjunção subordinativa $+E$, pensada como conjunção coordenativa, nos remetem ao que Bagno (2011, p. 884) diz sobre coordenação e subordinação enquanto propriedades semânticas dos enunciados; quer dizer, é perfeitamente possível construir um período subordinado com o emprego de uma conjunção prototipicamente coordenativa, como no exemplo: Faça isso de novo e eu te encho de porrada! = Se você fizer isso de novo, eu te encho de porrada!. O autor apoia a quebra dessa dicotomia, proposta por alguns gramáticos que defendem a ideia de uma relação correlacional, em que aparecem traços tanto de coordenação quanto de subordinação. No entanto, ele vai além, identificando uma quarta possibilidade de organização sintática: a hipotaxe adverbial. Trata-se de uma subdivisão das orações subordinadas, mantendo nestas as orações substantivas e as orações adjetivas, retirando as orações adverbiais. Bagno (2011) considera que a hipotaxe adverbial se estabelece predominantemente por locuções conjuntivas, em sua maioria, formadas por [preposição + QUE] ou [advérbio + QUE] (da mesma forma que, ainda que, desde que), representadas pelas orações temporais, comparativas, causais, condicionais e concessivas.

Assim, poderíamos considerar que o enunciado em questão, introduzido por " $E$ se" se encaixa nessa classificação - hipotaxe adverbial condicional, ainda que consideremos tendenciosa a classificação "condicional". Porém, Bagno (2011) apresenta uma alternativa para a conjunção $S E$, empregada como integrante quando tiver um sentido interrogativo, de forma direta ou indireta, ou negativo, citando Castilho que afirma que

Provavelmente, quando fazemos uma pergunta indireta, pressupomos diferentes respostas como hipóteses, o que teria levado a escolher o mesmo vocábulo conectivo em ambas as sintaxes. (CASTILHO, 2010, p. 357 apud BAGNO, 2011, p.894)

Exatamente é o que ocorre no enunciado em análise. Boris não espera uma resposta simples "sim" ou "não". Trata-se de uma questão retórica, que reforça a ideia de uma estratégia 
argumentativa. Por essa razão, propomos, para além das formas de emprego já apresentadas para "Y si" a função de operador argumentativo.

\subsubsection{Sobre a Tirinha 2}

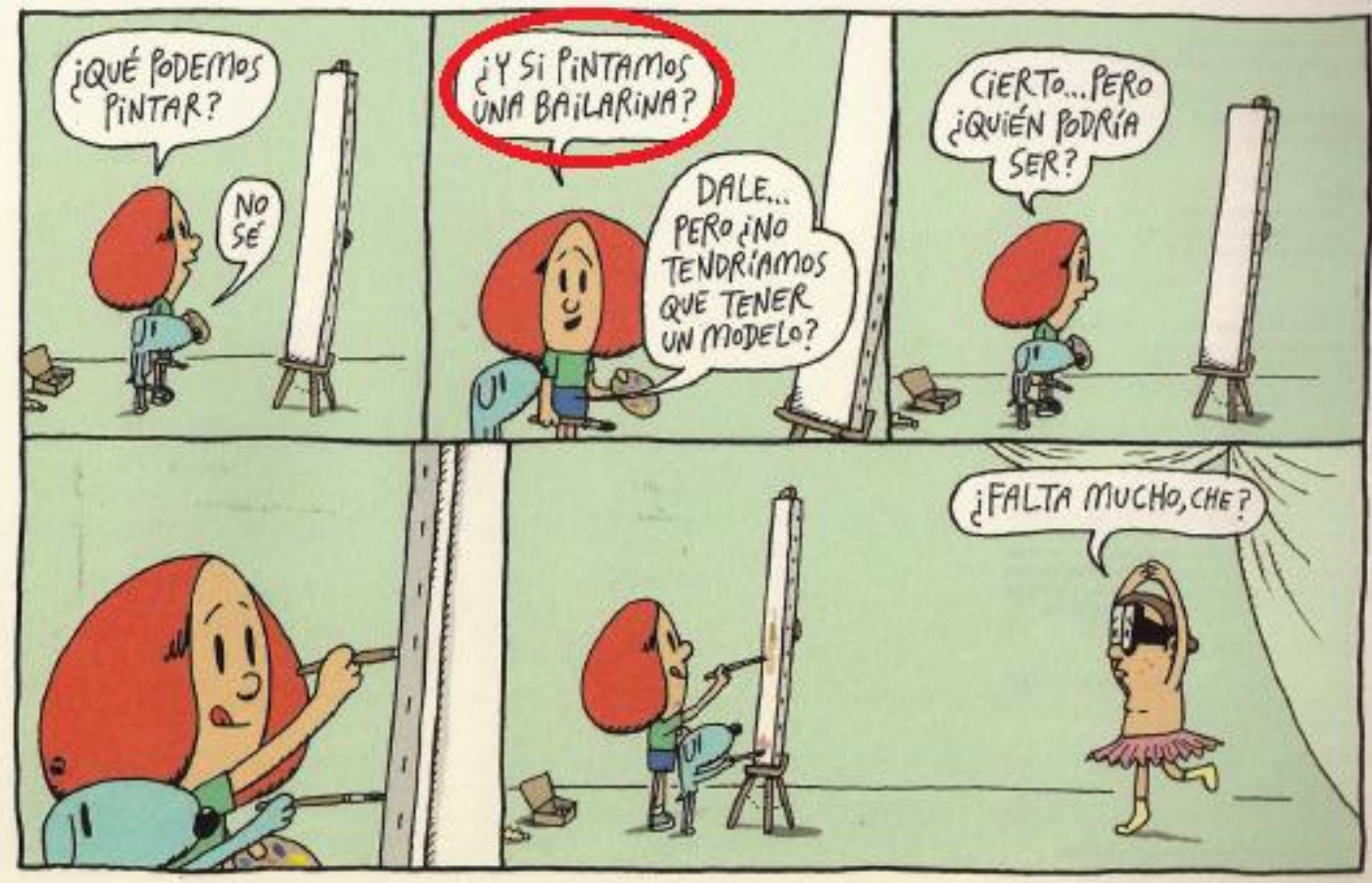

TUTE. Batu. Buenos Aires: Sudamericana, 2009

\subsubsection{Um breve relato}

A Tirinha 2 apresenta, no primeiro quadrinho, Batu diante de uma tela em branco e, junto ao seu amigo Tútum, está pensando sobre o que podem pintar. No segundo quadrinho, Batu expressa a ideia de pintar uma bailarina - ¿Y si pintamos una bailarina? Ao que Tútum pondera se não precisam, antes, buscar uma modelo. No terceiro quadrinho, Batu divide com Tútum sua dúvida sobre quem poderia servir de modelo. O quadrinho quatro mostra que a pintura está em andamento com os dois, Batu e Tútum, usando os pincéis. A solução encontrada por Batu aparece no último quadrinho, no qual vemos o amigo Boris no papel de modelo de bailarina. A situação parece não deixá-lo muito confortável, a julgar pela ansiedade que ele demonstra, explicitada por meio da pergunta final ¿Falta mucho, che?.

\subsubsection{Componentes do contexto}

Diferentemente da Tirinha 1, nesta situação, os elementos não verbais têm menor impacto na compreensão, visto o "contexto situacional", nos termos de Parret (1984) ou "situação comunicativa", nos termos de van Dijk (2012), ser facilmente identificado, por tratar-se de uma brincadeira que demanda menos da imaginação.

Nesta situação, os elementos verbais e não verbais combinados oferecem indícios e relações, nos termos de Parret (1984) para a compreensão do efeito de sentido do enunciado em 
destaque: A interrogativa introduzida por " $Y$ si" pode ser interpretada como uma sugestão em forma de cortesia, de forma a preservar a relação de amizade entre Batu e Tútum.

\subsubsection{Nossa análise}

Embora a Tirinha 2 traga uma situação de maior factibilidade que a Tirinha $1^{51}$, ou seja, apresenta-se uma condição plausível de realização no mundo real (crianças brincando de pintura em um ambiente fechado, provavelmente doméstico), para a compreensão, um novo modelo mental de contexto será elaborado. Van Dijk (2007) define que modelos de contexto estão relacionados de maneira geral a representações sociais compartilhadas com outros membros do mesmo grupo social ou comunidade. Assim, "modelos mentais de contextos são subjetivos, mas não arbitrários". A experiência dos participantes em milhares de outras situações de comunicação lhes permite generalizar e normalizar tais situações, como a organização de uma brincadeira, neste caso.

No segundo quadrinho, quando Batu fala ¿Y si pintamos una bailarina?, entendemos tratarse, de uma oração interrogativa que não constitui uma pergunta, pois Batu não espera uma resposta ou informação de Tútum. Tendo por base as afirmações de Escandell Vidal (1999), relativas à introdução de um enunciado utilizando a partícula $Y$ e considerando nossa proposição de que " $Y$ si" desempenha uma função de operador argumentativo, entendemos que esta, no enunciado destacado, tem função semelhante ao apresentado na Tirinha 1: Entendemos que Batu propõe ou sugere a Tútum sua ideia de utilizar uma bailarina como tema para sua pintura.

Não é possível avaliar sua intencionalidade, mas mesmo que a ideia de "pintar uma bailarina" já estivesse em seus planos, o uso de uma forma interrogativa, conforme Briz (2003), denota uma forma cortês de propor sua vontade. A resposta-pergunta de Tútum ¿No tendríamos que tener un modelo? permite-nos arriscar uma dupla intenção, nos termos de Koch (2011): A primeira, de fato, lembrar ao "pintor" que é necessário ter um modelo; a segunda, na possibilidade de que, na falta de um modelo, seria ele quem teria que desempenhar esse papel, Tútum, de maneira cortês, "sugere" que se busque um modelo, se desvencilhando da possibilidade dessa função, usando a mesma estratégia argumentativa de Batu.

A sequência de diálogos que se segue permite uma outra possibilidade de interpretação: É possível que Batu tivesse como intenção fazer de Tútum seu modelo. E, se assim for, poderemos considerar tratar-se, também, de uma forma polida ou velada de sugestão/convite, nos termos de Briz (2003), marcada não só pela modulação de pergunta, mas também pelo uso do Condicional Simple [tendríamos]. De acordo com Hilgert (2008), relações interpessoais envolvendo sujeitos diferentes em posições diferentes demandam

\footnotetext{
${ }^{51} \mathrm{Na}$ Tirinha 1, a situação de comunicação apresenta nossos personagens em uma condição totalmente imaginativa - crianças e um cachorrinho dentro de um navio, em alto mar, lutando contra piratas. Segundo Ibañez (1990), para a compreensão é necessária uma "construção mental com elementos da realidade circundante à interação", para elaboração do contexto situacional ou, nos termos de van Dijk (2007), a elaboração de um modelo mental de contexto.
} 
estratégias para a manutenção de uma relação harmoniosa. Ou seja, buscando sensibilizar o amigo Tútum para a necessidade de um modelo, Batu esperava que ele se prontificasse ao papel. Este, ao perceber a intenção de Batu, se desvencilha da situação com a pergunta ¿no tendríamos que tener un modelo?.

\subsection{A título de síntese}

A partir dos estudos e da análise dos elementos constituintes dessa estrutura $Y+s i / E+s e$, acreditamos que os enunciados em análise não pertençam às Orações Condicionais.

A título de síntese, apresentamos um esquema para o desenvolvimento de nossa análise:

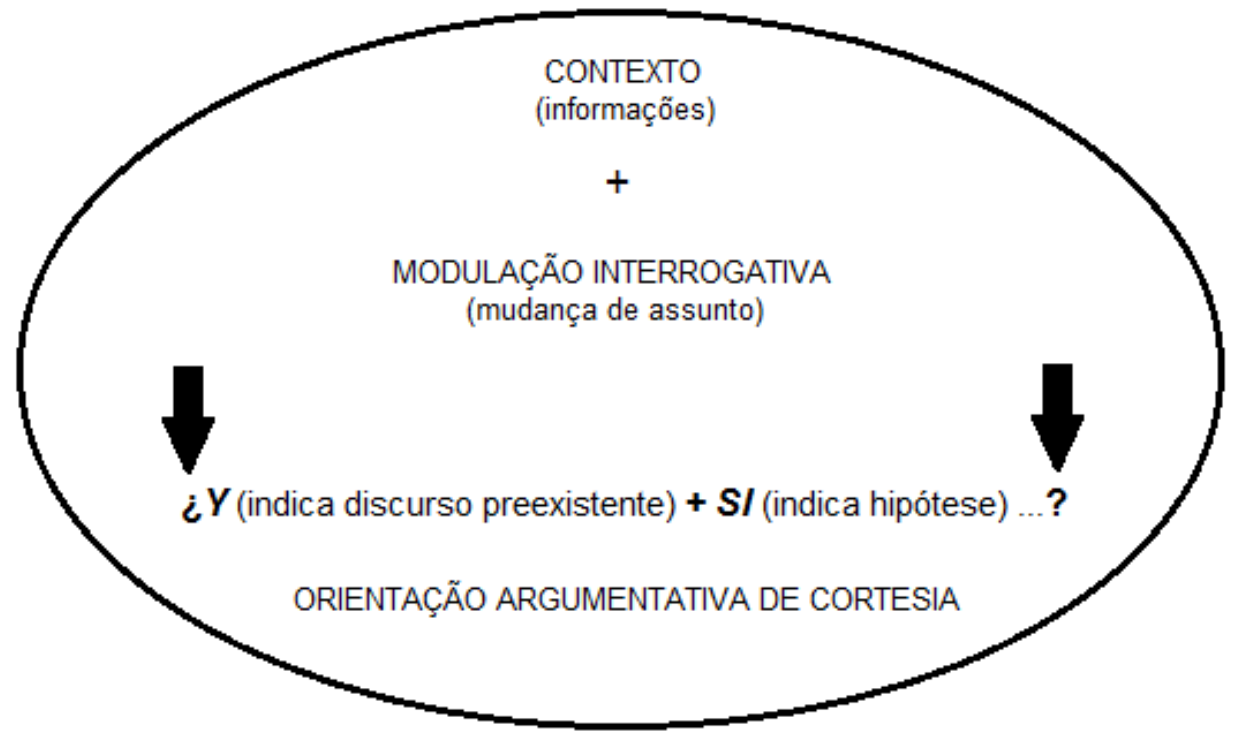

Fonte: Elaborado pela autora

Tomando por base, principalmente, os estudos de Portolés (1988) e Kock (2011), entendemos que " $Y$ si" tem força argumentativa e atua como operador argumentativo. A formulação em forma interrogativa orienta o enunciado no sentido de proposição ou sugestão de forma cortês, seja para uma nova brincadeira (Tirinha 1) ou para um tema para a nova pintura (Tirinha 2). Em comum, nas duas tirinhas, os personagens utilizam a cortesia como estratégia argumentativa para apresentar sua proposição. 


\section{CAPÍTULO 3 Análise dos dados}

"Podemos admitir que a compreensão textual se dá em boa medida como um processo inferencial, isto é, como uma atividade de construção de sentido em que compreender é mais do que extrair informações do texto: é uma atividade de produção de sentidos."

(Luiz Antônio Marcuschi, 1996, p.74)

\subsection{Introdução}

Neste capítulo, apresentamos os dados obtidos a partir das respostas dos informantes e respectivas análises e resultados parciais relativos a elas. As análises dos dados referentes a cada um dos Grupos: Grupo 1 - Tirinha 1 e Grupo 2 - Tirinha 2, serão tratados em itens separados.

\subsection{Dados da pesquisa}

Como informamos no Capítulo 2, contamos com as respostas de 40 informantes, aos quais foram atribuídas as atividades com uma das tirinhas, de forma aleatória. Assim, contamos com 21 sujeitos componentes do Grupo 1, dedicados às atividades de reformulação em português e relato da Tirinha 1, e 19 sujeitos componentes do Grupo 2, dedicados às atividades de reformulação em português e relato da Tirinha 2 . Lembramos que a identificação dos informantes se dá por meio da codificação explicada no Capítulo 2 (página 55).

As respostas dos sujeitos de pesquisa às duas atividades propostas ${ }^{52}$ foram compiladas em um quadro para cada grupo: Quadro 5: Compilação de respostas para a Tirinha 1 e Quadro 7: Compilação de respostas para a Tirinha 2. Por sua extensão, ambos estão disponíveis, integralmente, no Apêndice.

Para facilitar o entendimento do leitor, destacamos algumas das respostas apresentadas pelos sujeitos de pesquisa, a fim de exemplificar as ocorrências que deram suporte à elucidação das questões (já citadas na página 16) que nos moveram no desenvolvimento deste trabalho:

a) Checar se, para além das questões sistêmico-formais da língua espanhola, há influência de elementos discursivo-pragmáticos no eixo produção-compreensão;

b) O que está influenciando na compreensão? O que tem no contexto que ajuda ou atrapalha na compreensão?;

c) De que forma o contexto e a instrução formal podem (ou não) influenciar na compreensão deste tipo de enunciado?;

\footnotetext{
${ }^{52}$ As respostas foram transcritas da forma como os sujeitos as produziram, sem nenhuma correção.
} 
d) Como consequência da instrução formal sobre as Orações Condicionais com foco na metalinguagem, o que irá pesar mais na compreensão do aprendiz, a formalização dessas formas, o contexto, ambos ou, ainda, nenhum deles, já que segundo analisamos anteriormente os enunciados dos testes não se tratam de Orações Condicionais?

Além destas perguntas iniciais, durante as análises e leituras, surgiu outro questionamento, conforme se relatou na Introdução: a forma interrogativa, empregada no enunciado que utilizamos nos testes, constitui uma maneira cortês ou atenuadora de se posicionar frente ao seu interlocutor? E a locução conjuntiva " $Y$ si", é um operador argumentativo?

À luz do nosso entendimento sobre de que se compõe o contexto ${ }^{53}$, nossa análise se orientou pela observância de dois eixos: elementos verbais e elementos não verbais. Recordando, agrupamos como elementos verbais o código textual e as relações sintáticas e discursivopragmáticas. Para Parret (1985) trata-se do co-texto, em sua estrutura macro-gramatical, Ibañez (1990) também usa o conceito de cotexto ${ }^{54}$, o qual se compõe de elementos linguísticos, como as palavras. O eixo não verbal se constitui do conhecimento prévio, compartilhado ou não, do qual fazem parte elementos socioculturais e elementos icônicos.

Estamos de acordo com Bruno (2006, p.89), quando defende que "nem sempre a produção é reveladora da compreensão que de fato o aluno faz dessa forma". Por essa razão, analisamos as respostas da Atividade1 (reformulação das falas dos personagens) e da Atividade 2 (relato) de forma conjunta, por considerá-las complementares e possibilitarem, de forma cruzada, identificar se houve compreensão ou não e qual foi o efeito de sentido construído pelo informante.

Assim, organizamos nossa análise sob três categorias de ocorrências, envolvendo:

- elementos icônicos-Segundo Borges (2001, n.p.) “A técnica narrativa da história em quadrinhos envolve uma complexa relação entre dois canais, visuais e linguísticos, que permite ampliar as possibilidades de encaminhamento da mensagem e as perspectivas de recepção pelo destinatário.". Tais perspectivas estão associadas a construções sociais e culturais;

- elementos socioculturais-Os elementos socioculturais compõem o eixo não verbal do contexto e atribuímos a eles o elemento de maior influência na compreensão. Em acordo com Parret (1985), Ibáñez (1990) e van Dijk (2007, 2012), acreditamos que esta se dá a partir da interação entre os participantes e de processos cognitivos e discursivos, que estão influenciados pelas representações daqueles. Ou seja, dos valores sociais e culturais dos participantes que, compartilhados, privilegiam o êxito da comunicação;

\footnotetext{
${ }^{53}$ Vide esquema apresentado no final do Capítulo 1.

${ }^{54} \mathrm{Cf}$. nota de rodapé 67
} 
- elementos linguísticos -Além de aspectos relacionados ao código textual próprios dos enunciados em análise, em algumas situações, a reformulação das falas das personagens, referente à Atividade 1, demanda uma análise relativa à macroestrutura. Tais ocorrências serão apresentadas dentro da categoria de elementos linguísticos.

Passemos à análise dos dados.

\subsubsection{Análise dos dados do Grupo 1 - Tirinha 1}

Os dados obtidos pelas respostas dos informantes do Grupo 1, referem-se às atividades relacionadas à Tirinha 1, reproduzida na imagem abaixo. Em destaque, o enunciado cuja estrutura constitui nosso objeto de estudo.

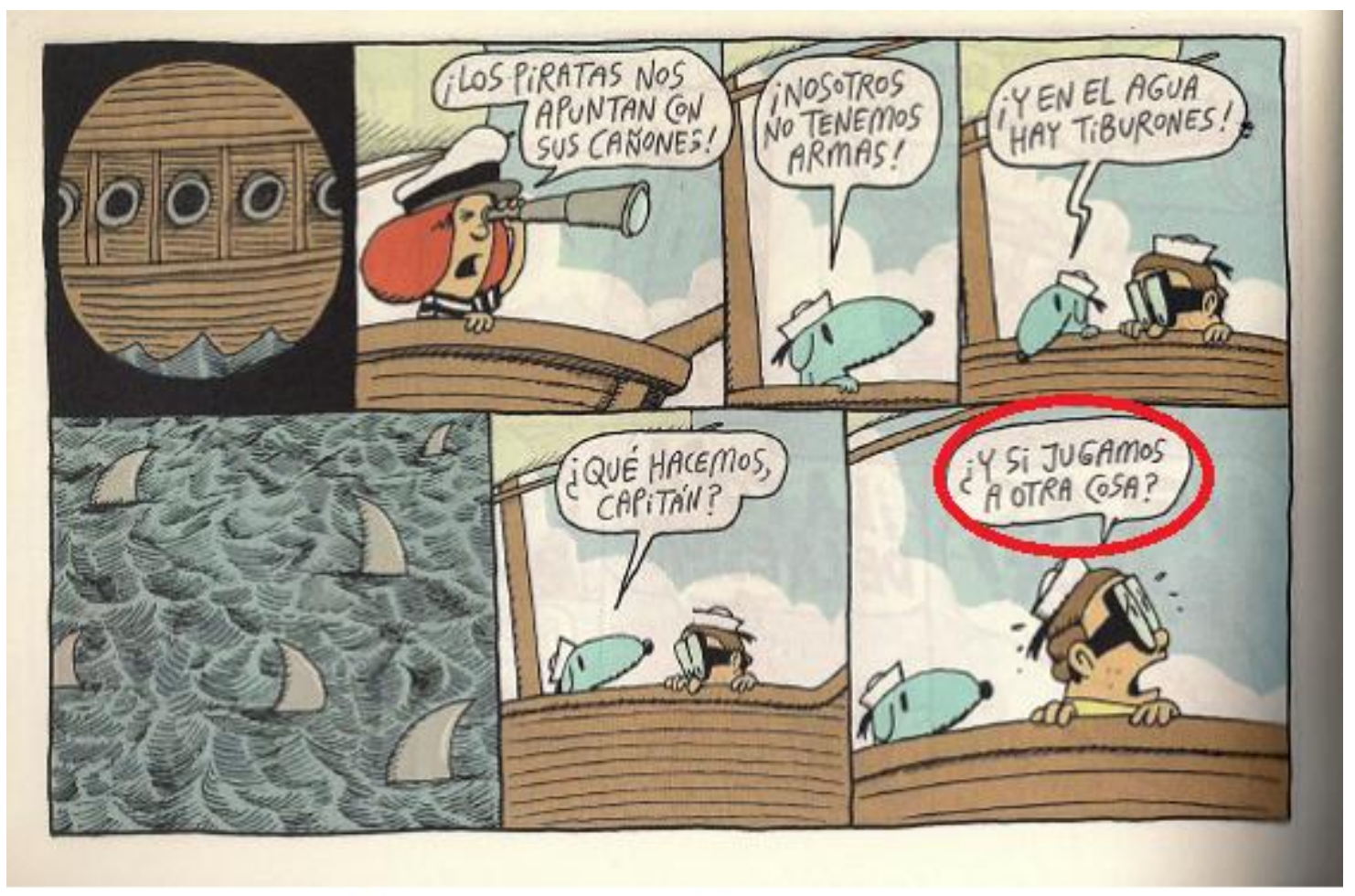

TUTE. Batu. Buenos Aires: Sudamericana, 2009

Os 21 componentes do Grupo 1 apresentaram a reformulação das falas dos personagens (Atividade 1) de forma muito semelhante. Como exemplo, reproduzimos a resposta de G1EM-002, que representa a reformulação de maior recorrência:

\footnotetext{
_Os piratas nos apontam com seus canhões!

_Nós não temos armas!

_Na água tem tubarão!

_O que fazemos capitão?

_E se jogarmos a outra coisa
}

Dezessete sujeitos reformularam as falas mantendo os verbos no tempo presente - nos apontam (12), nos ameaçam (1), miram (1) ou estão nos apontando (3). Quatro sujeitos 
usaram o tempo passado "apontaram". Dezenove interpretaram [jugar a] com o sentido de arremessar, usando [jogar] (18) ou [atirar] (1). Dentre eles, 4 mantiveram a preposição [a], 14 "apagaram" a preposição, e 1 sujeito substituiu a preposição [a] por [uma].

Somente dois sujeitos, usando, também o tempo presente ("miram" e "estão apontando"), identificaram [jugar a] com o significado de [brincar], G1-EM-016 e G1-UN-007, estes com idades de 16 e 20 anos, respectivamente.

$\begin{array}{ll}\text { G1-EM-016 } & \text { _Os piratas miram seus canhões para nós! } \\ & \text { _Nós não temos armas! } \\ & \text { _E na água tem tubarões! } \\ & \text { _O que fazemos, capitão? } \\ & \text { E se brincarmos de outra coisa? } \\ \text { G1-UN-007 } & \text { _Os piratas estão apontando seus canhões para gente! } \\ & \text { _Nós não temos armas! } \\ & \text { _E há tubarões na água! } \\ & \text { _O que faremos, capitão? } \\ & \text { _E se brincarmos de outra coisa? }\end{array}$

No entanto, durante a elaboração do Relato, solicitado na Atividade 2, outros dois sujeitos atribuíram ao enunciado em destaque ¿Y si jugamos a otra cosa? a opção de "mudar de brincadeira", conforme transcrevemos em seguida:

G1-EM-012 Duas crianças e um cachorro estavam velejando e se depararam com piratas que apontavam canhões para eles. O cachorro então os lembra que não possuem armas e estão cercados por tubarões, um dos marinheiros então sugere que mudem de brincadeira.

G1-UN-011 Dois garotos e um cãozinho estão brincando que são piratas. Para deixar a brincadeira mais emocionante, Batu, o menino de cabelos ruivos, diz que avista alguns piratas que estão armados e, como na "embarcação" que os meninos estão não possui armas e no "mar" existem tubarões, a melhor solução encontrada por Boris, o amigo de Batu, é perguntar se eles não podem trocar de brincadeira.

Na Atividade 2, os relatos dos sujeitos apresentaram algumas ocorrências relacionadas, principalmente, com elementos icônicos. Nada mais natural, visto estarmos tratando de um suporte narrativo que envolve uma dupla articulação de linguagem. Isso explica algumas diferenças observadas no eixo produção-compreensão entre a reformulação e o relato. Este propiciou ao sujeito informante a liberdade de "recontar" a estória com base apenas nas imagens. Por essa razão, iniciamos nossa análise pelas ocorrências relacionadas aos elementos icônicos. 


\subsubsection{Ocorrências relacionadas a elementos icônicos na Tirinha 1}

Nesta categoria, tratamos de ocorrências relacionadas à apreensão da situação global da estória por influência da imagem, que identificamos a partir dos relatos dos sujeitos informantes:

\subsubsection{1 "Apagamento" de Batu}

Dois sujeitos identificaram somente dois personagens. A partir de seus relatos, é possível afirmar que foi Batu quem passou despercebido:

G1-EM-004 Há dois tripulantes no navio e aponta outro navio pirata com seus canhões. Os dois tripulantes não tem armas e eles veem que na água há tubarões. Um deles pergunta o que fazer e o outro da uma sugestão.

G1-UN-009 Uma história na qual um menino e seu cachorro estavam em um barco e então alguns piratas os ameaçaram com seus canhões, eles não sabiam o que fazer, o cachorro disse que a água havia tubarões e então estavam sem saída então o menino deu a ideia de jogarem outra coisa.

Há somente "dois tripulantes", "um menino e seu cachorro". Entendemos que é Boris o menino citado por eles, pois é ele quem "da uma sugestão" ou "a ideia de jogarem outra coisa", como se observa nos dois últimos quadrinhos da tirinha, que destacamos abaixo. Ou seja, Batu desaparece de cena.

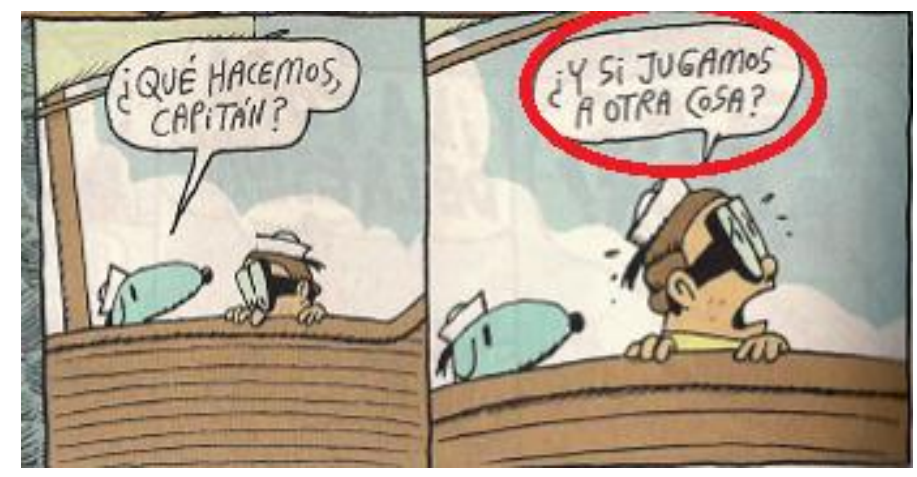

\subsection{Boris identificado como capitão}

Quatro informantes identificaram que era Boris o capitão, conforme se observa nos fragmentos dos seus relatos, que apresentamos abaixo:

G1-EM-010 ...ele pergunta o que vai fazer pro capitão e o capitão fala que pode jogar outra coisa.

G1-EM-024 ... O que fazemos agora capitão? capitão responde: sim jogamos outra coisa! 
G1-EM-030 ...perguntam ao capitão sobre o que fazemos e ele sugere jogar qualquer outra coisa para se defender

G1-UN-004 ... O cachorrinho pergunta ao capitão o que irão fazer, e ele responde se não eles não podem jogar outra coisa.

Novamente, os dois últimos quadrinhos, destacados anteriormente, levam os sujeitos informantes a essa interpretação. Tútum enuncia ¿Qué hacemos capitán? voltado para Boris, mas sua fala era dirigida ao capitão Batu, que não aparece nesta cena. No nosso entendimento, os sujeitos se atentaram para a imagem e se distraíram sobre que personagem exercia qual papel na situação. Ainda que nossa informação inicial aos sujeitos de pesquisa, sobre cada um dos personagens, pudesse ter sido negligenciada, o quepe usado por cada um deles os identificaria - marinheiros e capitão.

Certamente, a fala no quadrinho 6, em que somente Boris e Tútum estão presentes, "desviou a atenção" do leitor sobre a quem se dirigia o enunciado. Portanto, é possível afirmar que, no contexto desta cena, o icônico pesou mais que o enunciado; o local tirou o foco do global, visto que Batu, o capitão somente está presente no primeiro quadrinho. Por essa razão, estes informantes entenderam que Tútum falava com Boris, e, por tanto, este foi considerado o capitão.

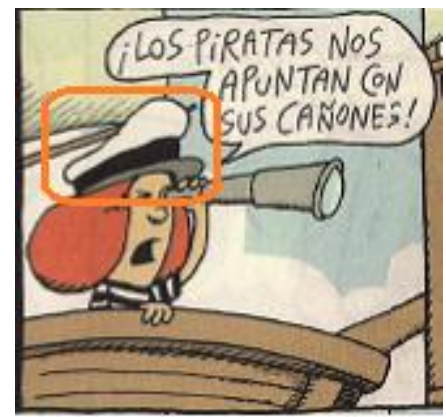

Quadrinho 2

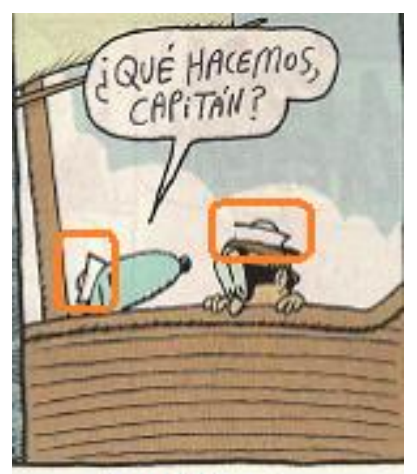

Quadrinho 6

\subsection{Tútum identificado como enunciador}

O sujeito G1-EM-028 relatou que o enunciado ¿Y si jugamos a otra cosa? teve a autoria de Tútum: "aí um cachorro pergunta se não podem jogar outra coisa". Acreditamos que por ter sido Tútum o enunciador no quadrinho 6 e, na sequência, sua posição ter sido mantida, o informante não se atentou para a origem do balão, com a fala de Boris. 


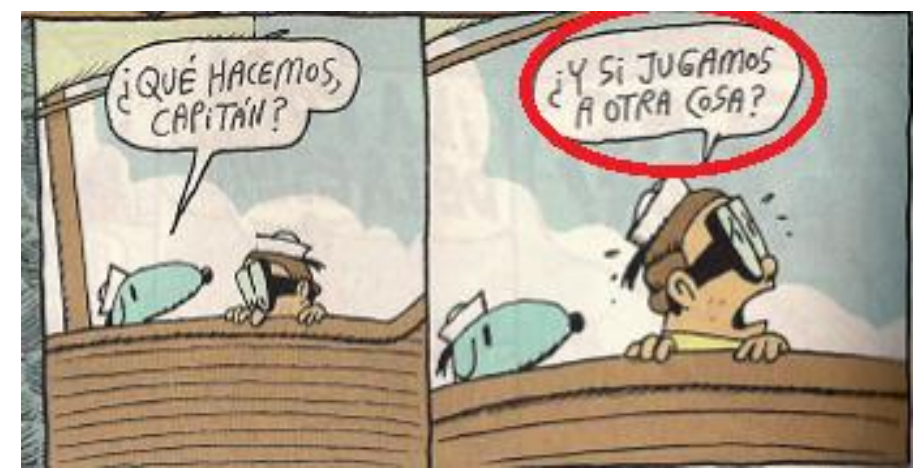

\subsection{Identificação dos personagens}

Onze sujeitos explicitaram ter identificado três personagens. Porém, dentre eles, os sujeitos G1-EM-006, G1-EM-016, G1-EM-021 e G1-UN-007 não deixam claro quem foi o autor do enunciado ¿Y si jugamos a otra cosa?, por utilizarem verbos na terceira pessoa do plural: "sugerem" ou "perguntam" ou a expressão "um deles" ou "um dos personagens".

Dos dez sujeitos restantes, G1-EM-004 e G1-UN-009 foram explícitos na identificação de somente dois personagens, pelo "apagamento de Batu". Os demais, em seu relato (Atividade 2) se referem aos personagens como "amigos" ou "eles", o que nos impossibilita registrar sua identificação. Com relação à identificação do autor do enunciado ¿'Y si jugamos a otra cosa?, além dos sujeitos citados nos itens anteriores, referentes à identificação de Boris como capitão e Tútum como enunciador, apontamos os relatos dos sujeitos G1-EM-017 e G1-EM020 que, por sua forma sintética e pela reprodução das falas, respectivamente, não explicitam quem foi o autor do enunciado. Destacamos o relato de G1-EM-005 por sua identificação explícita de Boris, como autor do enunciado:

G1-EM -005 São "piratas" (amigos) que não têm arma sendo alvo de piratas com arma, na água há tubarões e Boris opina em jogar (jugamos) outra coisa (cosa) neles; talvez jogar o piratas para os tubarões.

\subsection{Interpretação da imagem dos canhões}

Comprovando a influência da imagem, para a interpretação ${ }^{55}$, apresentamos as reformulações da Atividade 1, feitas por G1-EM-024, com destaque para as falas referentes aos quadrinhos dois e quatro.

No quadrinho 1, vemos os canhões que os piratas apontam, em uma imagem ampliada que ilustra o que Batu vê, por meio de sua luneta. Acreditamos que, influenciado por essa imagem, o sujeito interpretou os canhões como sendo uma série de lunetas, às quais denominou

\footnotetext{
${ }^{55}$ Empregamos, aqui, o termo interpretação à luz de uma utilização de Borges (2001), quando afirma que "o sentido de uma imagem será o conjunto de suas relações possíveis com as outras imagens que ela sugere: ao se isolar um sentido de um conjunto de outros, estaremos interpretando."
} 
telescópios (reformulação da fala do quadrinho 2). Na fala referente ao quarto quadrinho, o sujeito identifica a existência de "canhões" mas elabora uma construção inusitada, colocando "água nos canhões" ao invés de "tubarões na água". Interessante observar que no relato (Atividade 2) o sujeito cita a presença de tubarões mas mantém a "água nos canhões". Transcrevemos, abaixo, suas reformulações e seu relato.

\section{G1-EM-024}

_os piratas apontam com seus $\underline{\text { telescópios }}$

_os outros não tem armas

_tem água nos canhões

_o que fazemos capitão?

_e sim jogamos outra coisa? (quadrinho 2)

(quadrinho 3)

(quadrinho 4)

(quadrinho 6)

(quadrinho 7)
Que eles estão cercados de tubarões e tem água nos canhões e pede ajuda para o capitão e pergunta: $\mathrm{O}$ que fazemos agora capitão?

capitão responde: sim jogamos outra coisa!

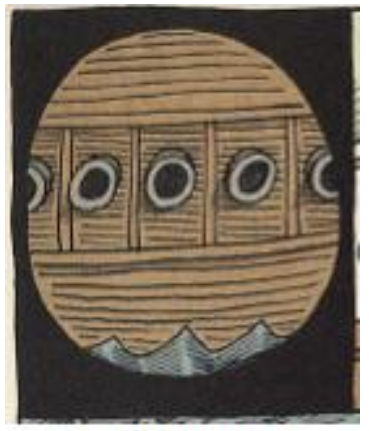

Quadrinho 1

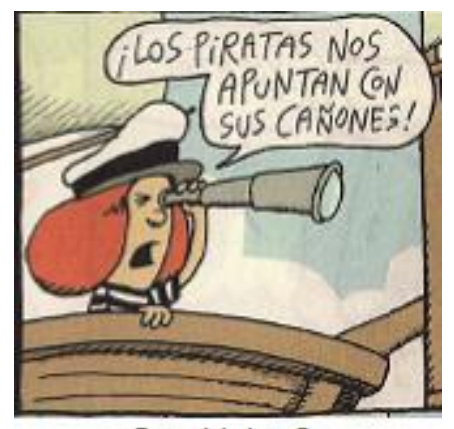

Quadrinho 2

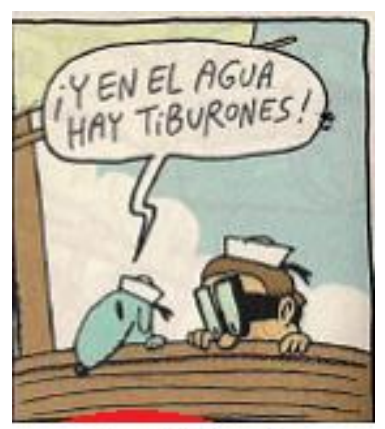

Quadrinho 4

\subsubsection{Ocorrências relacionadas a elementos socioculturais na Tirinha 1}

Nesta categoria, tratamos dos diferentes efeitos de sentido encontrados nos relatos dos sujeitos informantes. Identificamos, basicamente, três ocorrências importantes:

\subsection{Efeito de sentido de SUGESTÃO}

Da mesma forma como atribuímos o efeito de sentido de sugestão à locução conjuntiva " $Y$ si", conforme apresentamos em nossa análise, no Capítulo 2, doze informantes compreenderam que no enunciado ¿Y si jugamos a otra cosa? há um efeito de sentido de sugestão. Lembramos que os sujeitos informantes são aprendizes de E-LE de níveis iniciantes. No entanto, consideramos que esse desconhecimento não tenha sido impeditivo para esta compreensão, pois o contexto, com seus elementos constituintes, possibilitou esta construção de efeito de sentido.

Considerando [jugar a], cujo sentido, com os demais elementos deste enunciado, constitui uma sugestão para mudar de brincadeira, é possível supor que uma primeira reformulação tenha sido consequência da Transferência ${ }^{56}$ da Língua Materna (LM) para o Espanhol, pela

\footnotetext{
${ }^{56}$ Adotamos o termo Transferência a partir do entendimento de González (2005). A professora vê este processo não como uma simples transposição, mas como um "elemento cognitivo que intermedia o contato com a língua alvo e produz efeitos variados na produção estrangeira, um dos quais apenas é o de uma interlíngua calcada na L1". (GONZÁLEZ, 2005, p. 55)
} 
proximidade entre as duas línguas e, mais especificamente, neste caso, pela questão heterossemântica dos vocábulos [jugar] vs. [jogar].

Mas para quatro informantes, parece não ter feito muito sentido e, buscando outra possibilidade elaboraram um modelo mental da situação de perigo, com base em seus conhecimentos prévios relacionados a brincadeiras, e apresentaram a seguinte compreensão:

$\begin{array}{ll}\text { G1-EM-012 } & \begin{array}{l}\text {...um dos marinheiros então sugere que } \\ \text { mudem de brincadeira }\end{array} \\ \text { G1-EM-016 } & \begin{array}{l}\text {...um deles sugere que } \\ \text { brincadeira }\end{array} \\ \text { G1-UN-007 } & \begin{array}{l}\text {... Então, um dos personagens sugere que } \\ \text { troquem de brincadeira. }\end{array} \\ \text { G1-UN-011 } & \begin{array}{l}\text {...a melhor solução encontrada por Boris, o } \\ \text { amigo de Batu, é perguntar se eles não } \\ \text { podem trocar de brincadeira. }\end{array}\end{array}$

Os sujeitos G1-EM-006 e G1-UN-009 compreenderam o sentido de sugestão, mas relacionaram [jugar a] com seu significado no PB. Dessa forma, sua construção manteve a ambiguidade do verbo [jogar] que permite as duas possibilidades: mudar de brincadeira ou arremessar algo:
G1-EM-006 ...Então, eles se perguntaram o que devem fazer, e sem saber o que fazer, sugerem jogar outra coisa.
G1-UN-009 ...então o menino deu a ideia de jogarem outra coisa.

Outros quatro informantes compreenderam também o sentido de sugestão, mas para arremessar alguma coisa contra os piratas ou contra os tubarões:

G1-EM-002 ...Um dos seus tripulantes pergunta o que eles vão fazer já que não tem armas, o outro fala "e se jogarmos a outra coisa? Essa outra coisa poderia ser o capitão pra distrair os tubarões e saírem nadando.

G1-EM-005 São "piratas" (amigos) que não têm arma sendo alvo de piratas com arma, na água há tubarões e Boris opina em jogar (jugamos) outra coisa (cosa) neles; talvez jogar o piratas para os tubarões 


\section{G1- EM-030 ...perguntam ao capitão sobre o que fazemos e ele sugere jogar qualquer outra coisa para se defender \\ G1-UN-004* O cachorrinho pergunta ao capitão o que irão fazer, e ele responde se não eles não podem jogar outra coisa.}

Pelo relato, poderíamos interpretar que G1-UN-004 deixa ambígua sua construção com relação a arremessar ou mudar de brincadeira, no entanto, esta se esclarece em sua reformulação da fala do quadrinho 7: "E se atirarmos outra coisa?".

Considerando a possibilidade de lançar outra coisa na água, G1-EM-002 e G1-EM-005 acrescentam um elemento novo a essa interpretação: a comicidade. Lançar o capitão ou os piratas aos tubarões imprime um duplo sentido à sugestão de Boris.

Esse duplo efeito de sentido encontra explicação em Koch (2011), quando a autora afirma que "Não basta conhecer o significado literal das palavras ou sentenças de uma língua: é preciso saber reconhecer todos os seus empregos possíveis, que podem variar de acordo com as intenções do falante e as circunstâncias de sua produção". (KOCH, 2011, p.27). Tais circunstâncias estão limitadas pelo contexto, nos termos de Parret (1985).

Estes sujeitos, claramente, compreenderam a sugestão do personagem Boris, mas num primeiro momento o co-texto não ajuda ou lhes dá segurança para tentar uma opção que permita equivaler [jugar a] a [brincar]. Porém, influenciados pela LM e pela própria materialidade linguística, que neste caso, contribui para a falta de compreensão, vêm a possibilidade de "jugar" como "atirar". O contexto situacional não foi suficiente para desfazer a ambiguidade, mas elementos socioculturais foram fundamentais para permitir aos participantes vislumbrar mais de uma possiblidade, que o co-texto teria restringido, confirmando uma observação que apresentamos anteriormente, relativa à importância atribuída por Parret (1985) à contextualização.

Considerando que o autor dedica seu estudo à LM, no nosso entender, Parret (1985) parece desconsiderar outros fatores que interferem na compreensão, como se o falante tivesse controle absoluto sobre o processo, mas a compreensão está condicionada a uma colaboração mútua e à possibilidade de interpretação, pelos sujeitos envolvidos, da situação em que os diálogos são produzidos.

Os participantes usam seu conhecimento de mundo e suas experiências em outras situações de comunicação para construir um modelo mental e elaborar o contexto (cf. van Dijk, 2007) e, neste caso, a proximidade entre as línguas foi como uma "armadilha" que contribuiu para confundi-los, mas os elementos para a contextualização foram suficientes para que os sujeitos elaborassem a totalidade do contexto de forma eficaz. 
Os sujeitos G1-EM-004 e G1-UN-005 explicitaram o efeito de sentido de sugestão, mas sem determinar para fazer o quê:

G1-EM-004 $\begin{aligned} & \text {...Um deles pergunta o que fazer e o outro da } \\ & \text { uma sugestão. }\end{aligned}$
G1-UN-005
$\begin{aligned} & \text {...ao que o outro personagem sugere uma } \\ & \text { nova solução ao capitão. }\end{aligned}$

Ambos apresentaram "E se jogarmos outra coisa?" como reformulação para o enunciado da fala 5. Acreditamos que com base em seus conhecimentos de português e devido à similaridade de sentido de " $E$ se" na LM, compreenderam o sentido de sugestão, mas tendo ficado inseguros com o significado de jugar, preferiram não se comprometer com o teor dessa sugestão.

\subsection{Efeito de sentido de AUTORIZAÇÃO}

Atribuímos à modulação interrogativa do enunciado, aliada à presença de uma autoridade o capitão, a interpretação de um pedido de autorização, por quatro informantes:

$\begin{array}{ll}\text { G1-EM-010 } & \begin{array}{l}\text {... ele pergunta o que vai fazer pro capitão e } \\ \text { o capitão fala que pode jogar outra coisa. }\end{array} \\ \text { G1-EM-021 } & \begin{array}{l}\text {... E então perguntam para o capitão } \\ \text { poderiam jogar outra coisa }\end{array} \\ \text { G1-EM-024 } & \begin{array}{l}\text {... pede ajuda para o capitão e pergunta: O } \\ \text { que fazemos agora capitão? } \\ \text { capitão responde: sim jogamos outra coisa! }\end{array} \\ \text { G1-EM-028 } & \begin{array}{l}\text {...eles entram em dúvida no que fazer, aí um } \\ \text { cachorro pergunta se não podem jogar outra } \\ \text { coisa, como os tubarões }\end{array}\end{array}$

\subsection{Efeito de sentido de DÚVIDA}

Acreditamos que o desconhecimento do significado da palavra jugar, levou o informante G1EM-015 a interpretar tratar-se de um erro de "julgamento". Ele põe em dúvida se a situação é de fato o que está se apresentando:

G1-EM-015 Os piratas estão apontando seus "canhões" para o barco de Batu, e o cãozinho observa que eles não tem armas, e na água tem tubarões, porém o menino de óculos questiona se eles não viram errado. 


\subsection{Efeitos de sentido não explicitados}

Observamos quatro ocorrências cujos relatos não permitem identificar qual foi a construção de sentido dos sujeitos, seja por terem sido feitos com a reprodução das falas (G1-EM-007 eG1-EM-020), seja por ter sido um relato bastante sintético (G1-EM-017) ou mesmo com um relato detalhado, mas que reproduz o enunciado em análise sem explicitar qual o efeito de sentido (G1-EM-019):

$\begin{array}{ll}\text { G1-EM-007 } & \text { Batu: Os piratas nos aponta com seus } \\ \text { canhões! } \\ \text { Tutum: Nós não temos nenhuma arma! } \\ \text { Tutum: E a água tem tubarões } \\ \text { Tutum: O que fazemos capitão? } \\ \text { Boris: E se jogarmos outra coisa? } \\ \text { Os piratas apontam o canhão! } \\ \text { Nós não temos armas! } \\ \text { Na água há tubarões. } \\ \text { O que fazemos capitão? } \\ \text { E se jogarmos outra coisa? }\end{array}$

G1-EM-017 Um quadrinho que relata que tem dois barcos um contém piratas apontando canhões para um desarmado e as águas tem tubarões.

G1-EM-019 Eu entendi que o Batu é o capitão e o tútum e o Boris são os marinheiros. Eles estão navegando, quando um navio pirata aponta os canhões para eles, eles sem armas e sem saber o que fazer, pensam em até pular na água mais está cheia de tubarões, então Boris pergunta "e se jogarmos outra coisa".

Acreditamos que tenha ocorrido neste caso algo semelhante com o que verificamos anteriormente com dois informantes (G1-EM-004 e G1-UN-005) que explicitaram compreender tratar-se de uma sugestão, mas, talvez por preservar-se, não foram além nessa sugestão. A reprodução das falas de G1-EM-007 e de G1-EM-020 não possibilita averiguar sua compreensão. Mas G1-EM-017 e G1-EM-019 demonstraram ter compreendido a situação global e é possível supor que este último, tenha evitado expor uma compreensão incompleta ou parcial.

\subsection{Cruzamento entre as ocorrências de elementos icônicos e o efeito de sentido explicitado pelos sujeitos informantes na Tirinha 1}

A princípio, acreditávamos que as ocorrências relacionadas a elementos icônicos poderiam ter alguma influência na compreensão e/ou na construção de efeitos de sentido. No entanto, 
verificamos que esta se deu de maneira independente da forma como os sujeitos da pesquisa interpretaram as imagens.

O quadro da sequência apresenta um cruzamento entre as ocorrências relacionadas ao elemento icônico, com relação à identificação dos personagens e seus respectivos papéis, por parte dos informantes (o que poderia ter influenciado na sua compreensão) e o efeito de sentido que estes atribuíram ao enunciado em análise ¿Y si jugamos a otra cosa?

\begin{tabular}{|c|c|c|c|c|c|}
\hline \multicolumn{6}{|c|}{ Quadro 6 - Construção de efeito de sentido versus elemento icônico na Tirinha 1} \\
\hline $\begin{array}{r}\begin{array}{r}\text { Elemento } \\
\text { icônico }\end{array} \\
\text { Efeito de } \\
\text { sentido }\end{array}$ & $\begin{array}{c}\text { Apagamento } \\
\text { de Batu }\end{array}$ & $\begin{array}{l}\text { Boris como } \\
\text { capitão }\end{array}$ & $\begin{array}{c}\text { Tútum } \\
\text { como } \\
\text { enunciador }\end{array}$ & $\begin{array}{c}\text { Não } \\
\text { identificação } \\
\text { dos } \\
\text { personagens }\end{array}$ & $\begin{array}{l}\text { Identificação } \\
\text { dos } \\
\text { personagens }\end{array}$ \\
\hline $\begin{array}{l}\text { Sugestão } \\
\text { (mudar de } \\
\text { brincadeira) }\end{array}$ & & & & & $\begin{array}{l}\text { G1-EM-012 } \\
\text { G1-EM-016 } \\
\text { G1-UN-007 } \\
\text { G1-UN-011 }\end{array}$ \\
\hline $\begin{array}{l}\text { Sugestão } \\
\text { (ambígua) }\end{array}$ & G1-UN-009 & & & & G1-EM-006 \\
\hline $\begin{array}{c}\text { Sugestão } \\
\text { (arremessar) }\end{array}$ & & $\begin{array}{l}\text { G1-EM-030 } \\
\text { G1-UN-004 }\end{array}$ & & G1-EM-005 & G1-EM-002 \\
\hline $\begin{array}{l}\text { Sugestão (sem } \\
\text { ação especifica) }\end{array}$ & G1-EM-004 & & & & G1-UN-005 \\
\hline $\begin{array}{l}\text { Autorização } \\
\text { (dada ou } \\
\text { solicitada) }\end{array}$ & & $\begin{array}{l}\text { G1-EM-010 } \\
\text { G1-EM-024 }\end{array}$ & G1-EM-028 & & G1-EM-021 \\
\hline $\begin{array}{c}\text { Dúvida ou } \\
\text { questionamento }\end{array}$ & & & & & G1-EM-015 \\
\hline Não identificado & & & & $\begin{array}{l}\text { G1-EM-007 } \\
\text { G1-EM-017 } \\
\text { G1-EM-020 }\end{array}$ & G1-EM-019 \\
\hline
\end{tabular}

Verifica-se que, independentemente da correta identificação dos três personagens e de seus respectivos papeis (10 informantes o fizeram), somente 5 dos 21 informantes não compreenderam tratar-se de uma sugestão, não contabilizando os informantes G1-EM-007, G1-EM-017, G1-EM-019 e G1-EM-020, cujo efeito de sentido não foi identificado por não explicitaram sua compreensão de forma clara, conforme ponderamos no item anterior.

Considerando a atitude destes e lembrando que outros dois sujeitos (G1-EM-004 e G1-UN005) compreenderam tratar-se de uma sugestão, mas não "se arriscaram" em definir o que significava [jugar], acreditamos na possibilidade de que todos estes sujeitos tenham optado por evitar demonstrar uma compreensão parcial da situação.

Podemos concluir que a identificação ou não dos personagens não teve influência direta na intepretação do efeito de sentido do enunciado como sugestão. Esse resultado corrobora com 
nosso entendimento de que o efeito de sentido advém de uma construção sociocultural que o operador argumentativo " $Y$ si" evoca 57.

\subsubsection{Ocorrências relacionadas a elementos linguísticos na Tirinha 1}

Relativo à Atividade 1, observamos que todos os sujeitos adotaram o infinitivo pessoal ${ }^{58}$ na reformulação do enunciado ¿Y si jugamos a otra cosa?, usando "jogarmos", "atirarmos" ou "brincarmos", com exceção de G1-EM-024:

$\begin{array}{cl}\text { G1-EM-024 } & \text { _os piratas apontam com seus telescópios } \\ & \text { _os outros não tem armas } \\ & \text { _tem água nos canhões } \\ & \text { _o que fazemos capitão? } \\ & \text { _e } \operatorname{sim}^{59} \text { jogamos outra coisa? }\end{array}$

Independentemente de os sujeitos terem compreendido ou não o falso cognato [jugar a], foi possível evidenciar que eles compreenderam o efeito de sentido do enunciado. Ou seja, em sua maioria (doze, dos dezessete informantes), compreenderam o enunciado em questão como uma forma de sugestão, seja para buscar outra brincadeira ou para buscar outra coisa para tirar à água.

\subsubsection{Resultados parciais referentes à Tirinha 1}

Aceitar como verdadeira a situação posta, (pensando na natureza inferencial da compreensão, cf. Sperber e Wilson, 1994a, p.87) mesmo tratando-se de uma brincadeira, constitui um imaginário que faz parte da construção social e cultural dos sujeitos. Aliado ao co-texto, este conhecimento foi o que lhes permitiu elaborar o contexto situacional, nos termos de Parret (1985), compreender a estória e construir um efeito de sentido de sugestão.

Não achamos possível, portanto, delimitar o que pesa mais na compreensão, o código ou a imagem, o verbal ou o não verbal. Concordamos com Borges (2001) quando afirma que "a interpretação do não verbal, assim como do verbal, pressupõe a relação com acultura, com o histórico, com a formação social do sujeito intérprete". Reconhecer, por exemplo, o papel dos personagens e a hierarquia entre os tripulantes e o capitão a partir dos quepes faz parte de um universo cultural que nem sempre está acessível a todos.

\footnotetext{
${ }^{57} \mathrm{Cf}$. Ibañez - Ver nota de rodapé 29.

${ }^{58} \mathrm{Um}$ estudo sobre esta opção modo-temporal, por aprendizes de E-LE, falantes nativos de PB, pode ser visto em Ballesteros (2016).

${ }^{59}$ Considerando a reprodução da fala 5, substituindo SI por SIM, conforme apresentamos, acreditamos que o sujeito tenha compreendido SI como sí e, desta forma, fez uma pergunta com uma afirmativa, para a qual teria faltado uma vírgula "E sim, jogamos outra coisa?"
} 


\subsubsection{Análise dos dados do Grupo 2 - Tirinha 2}

Os dados obtidos pelas respostas dos informantes do Grupo 2, referem-se às atividades relacionadas à Tirinha 2, reproduzida na imagem a seguir. Em destaque, o enunciado cuja estrutura constitui nosso objeto de estudo.

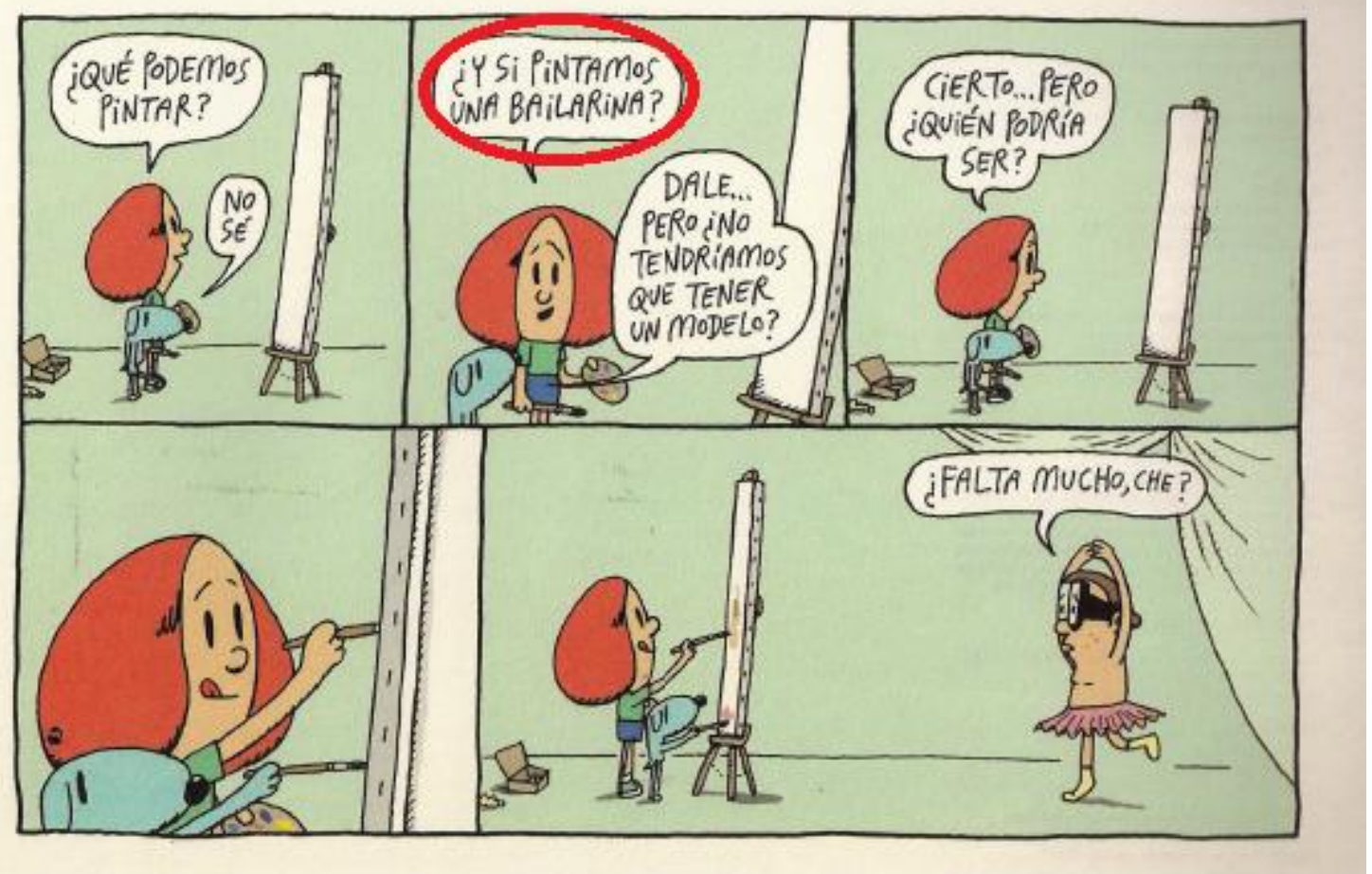

TUTE. Batu. Buenos Aires: Sudamericana, 2009

A reformulação das falas dos personagens (Atividade 1) apresentadas pelos 19 informantes manteve uma grande semelhança com as falas originais, seja no aspecto modo-temporal dos verbos, seja no aspecto lexical. A resposta que reproduzimos abaixo, do sujeito G2-EM-001, representa a reformulação de maior recorrência:

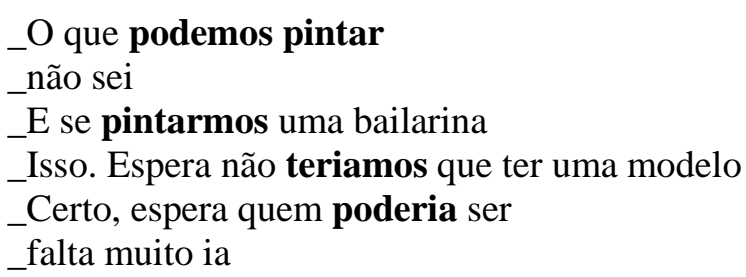

Destacamos em negrita os elementos que, em alguma resposta, apresentaram alguma variação. Por exemplo, [podemos pintar] foi a forma adotada por 17 sujeitos (destes, G2-UN001 substituiu "pintar" por "desenhar", mas sobre este sujeito, apresentamos um destaque, mais adiante).

Os dois sujeitos que optaram por uma alteração modo-temporal daquele elemento, apresentaram também uma reformulação diferente dos demais sujeitos para a fala 3 , a qual 
contempla o enunciado que trouxemos como objeto de nossa pesquisa: ¿Y si pintamos una bailarina?, conforme apresentamos em seguida:

\begin{tabular}{|c|c|c|}
\hline G2-EM-014 & $\begin{array}{l}\text { _O que poderemos pintar? } \\
\text { _Não sei } \\
\text { _E se pintassemos uma bailarina? } \\
\text { _Vale... Mas não teríamos que ter } \\
\text { um modelo? } \\
\text { _Certo... Mas quem poderia ser? } \\
\text { _Falta muito? }\end{array}$ & $\begin{array}{l}\text { Batu, juntamente com seu cão } \\
\text { pensa em fazer uma pintura } \\
\text { qualquer. }\end{array}$ \\
\hline G2-UN-010 & $\begin{array}{l}\text { _O que poderíamos pintar? } \\
\text { _Não sei } \\
\text { _E se pintássemos uma bailarina? } \\
\text { _Muito bom... Mas, não } \\
\text { precisamos antes, ter um modelo? } \\
\text { _É verdade... Mas, quem poderia } \\
\text { ser? } \\
\text { _Falta muito, Batu? }\end{array}$ & $\begin{array}{l}\text { A tirinha fala sobre um garoto e } \\
\text { seu cãozinho, que estavam } \\
\text { brincando de pintores; mas antes } \\
\text { de começarem a brincadeira } \\
\text { conversaram para decidir o que } \\
\text { iriam pintar. }\end{array}$ \\
\hline
\end{tabular}

O uso do pretérito de Subjuntivo na reformulação de Orações Condicionais, em Espanhol, foi um dos temas abordados em nossa IC, bem como as variações modo-temporais e seus efeitos de sentido. Por não ser este o objeto desta dissertação, não nos aprofundamos em análises deste tipo de ocorrência ${ }^{60}$. Mas, para a análise das respostas apresentadas acima, destacamos, daquele trabalho, um conceito de Leão (1961, p. 60), citado e defendido por Castilho (2014, p. 375) que atribui a ideia de condição ou hipótese não só à conjunção, mas também ao tempo e ao modo verbal. No caso do falante de PB, evidenciamos, naquela oportunidade, que este recorre preferentemente ao modo Subjuntivo quando o enunciado permite uma pressuposição. Trata-se de uma oposição semântica com relação à factualidade: em uma asserção, o falante exprime sua crença de que o que se segue é verdadeiro utilizando o modo Indicativo; quando o enunciado permite uma pressuposição, ou seja, a verdade é inferida pelo receptor, o verbo fica no modo Subjuntivo (BALLESTEROS, 2016, p.22).

Acreditamos que as respostas apresentadas anteriormente representam um exemplo dessa estratégia. Conforme destacamos nos relatos, ambos os sujeitos compreenderam haver uma negociação entre os personagens sobre o que pintar, pressupondo um acordo.

Chamamos a atenção para o fato de que tal opção na reformulação da fala do segundo quadrinho - "E se pintássemos uma bailarina?" - foi adotada por um sujeito de cada categoria: um aluno do Ensino Médio e um estudante de pós-graduação. Ou seja, independentemente da maturidade intelectual, ambos fizeram o mesmo tipo de escolha discursiva.

Segundo Borges (2001), "a mensagem icônica e a verbal nos quadrinhos não se excluem, mas interagem, combinando de tal forma a ponto de permitir novas possibilidades de encaminhamento e de recepção da mensagem". Comprovando a influência do componente

\footnotetext{
${ }^{60}$ Maiores detalhes daquele trabalho, podem ser vistos em BALLESTEROS (2016).
} 
cultural para a compreensão da imagem, evidenciamos diferenças no eixo produçãocompreensão, como proposto por Bruno (2006), entre a reformulação e o relato, que em sua maioria estão relacionadas ao elemento visual.

Com base na ideia de que a interpretação de um texto não só pressupõe a interação de regras de produção e de recepção, mas também o "contexto de experiência anterior no qual se inscreve a percepção estética", Joly $(2007$, p.70) afirma que "é capital compreender que aquilo que serve de base, antes de tudo o mais, à compreensão individual de um texto e ao efeito que ele produz é este horizonte de uma experiência estética intersubjetiva preliminar". Sendo assim, o conhecimento prévio do leitor é um componente diferencial para a qualidade de sua compreensão. Ou seja, conforme sua experiência estética, a imagem poderá resultar numa não compreensão. ${ }^{61}$

\subsubsection{Ocorrências relacionadas a elementos icônicos na Tirinha 2}

As ocorrências relacionadas à interpretação da estória, influenciadas pela imagem, não comprometeram a compreensão da situação global da narrativa, mas revelam a força do componente sociocultural na compreensão.

\subsection{Batu visto como uma menina}

Conforme mencionamos, no Capítulo 2, na descrição da Metodologia, antes das atividades, fornecemos aos sujeitos algumas informações preliminares, com a apresentação dos personagens e do autor das tirinhas:

As atividades estão relacionadas a uma tirinha de Tute (Juan Matías Loiseau), escritor argentino, que nos apresenta alguns personagens: Batu, um garoto de cabelos ruivos, sempre acompanhado de seu cãozinho azul, Tútum e de seu amigo Boris (garoto com óculos).

Apesar desta informação inicial, sete sujeitos relataram a presença de uma menina dentre os personagens.
G2-EM-013 Esse quadrinho é uma menina e um cachorro pintando...

G2-EM-018 Uma menina que queria pintar algo, mas ela não sabe o que seria esse algo...

G2-EM-023 A garota ruiva quer pintar algo ...

\footnotetext{
${ }^{61}$ Com relação à aprendizagem de leitura de imagens, a autora cita o caso de "certas pessoas adultas nunca viram imagens, por viverem em zonas afastadas onde a tradição cultural não emprega a imagem figurativa. As imagens figurativas reduzem-se então para estas pessoas a conjuntos de cores e formas que em caso algum remetem para elementos da realidade". (JOLY, 2007, p.47)
} 
G2-EM-027 Uma moça que tenta fazer uma pintura de uma bailarina...

G2-EM-029 Que uma menina quer fazer uma pintura ...

G2-UN-006 A menina estava sem ideias do que pintar...

G2-UN-008 Acabo de ler uma tirinha cômica que se passa com uma menina e seu cão ...

Atribuímos essa interpretação (cf Borges, 2001) a um pré-conceito cultural: meninas têm cabelos longos e meninos, cabelos curtos. Interessante foi o relato de G2-EM-022 que, inicialmente, identifica Batu como menino. Mas no decorrer do relato, fala d'ela.

G2-EM-022 Um menino e seu cão queriam pintar algo e o menino deu a ideia de pintarem uma bailarina e seu cão pergunta se eles não precisariam de um modelo ela em seguida pensa quem poderia ser este modelo...

É possível supor que no início de seu relato, o sujeito tenha se baseado na informação previamente fornecida. Mas, no decorrer do desenvolvimento da atividade, consultando a imagem, o elemento icônico teve maior peso e, como os sete sujeitos citados anteriormente, deixou-se levar pela força da imagem dos cabelos longos relacionando-a com uma cabeleira feminina.

\subsubsection{2"Apagamento” de Tútum}

O sujeito G2-EM-009 parece ignorar a presença de Tútum:

G2-EM-009 Um menino tem a ideia de pintar uma bailarina mais não tem um modelo ai resolve personalizar um menino de bailarina de modelo.

Talvez porque o cachorrinho apareça sempre na mesma posição, bem pequeno, ao lado de Batu, possa ter-lhe parecido um acessório. Certamente, o sujeito ignorou parte das informações iniciais e desconsiderou as falas de Tútum.

\subsection{O desenho de uma árvore?}

No início desta seção, quando apresentamos as formas mais recorrentes de reformulação das falas, citamos o sujeito G2-UN-001, como o único informante que substituiu "pintar" por "desenhar". Mas o mais instigante, na sequência de respostas deste sujeito, na atividade de reformulação, foi a reelaboração das falas, conforme reproduzimos abaixo: 
G2-UN-001_O que podemos desenhar?

_Não sei.

_E se desenharmos uma árvore?

_Vamos... Mas, não precisávamos ter uma como modelo?

_Certo... Vamos procurar uma?

_Falta muito para acharmos?
Um menino pergunta para seu companheiro, um cãozinho. $\mathrm{O}$ que eles poderiam pintar? E o cãozinho não sabia. Então tiveram a ideia de pintar uma bailarina, mas eles imaginaram que deveriam ter um modelo. Então um amigo foi o modelo de bailarina para a pintura. $\mathrm{E}$ ele no fim perguntou se iria demorar muito ainda.

Chamamos a atenção para o fato de que ao reformular, o verbo "pintar", da versão original, foi substituído pelo verbo "desenhar", nas duas falas em que aparece (fala 1 e fala 3). Por sua vez, no relato, o sujeito passou a usar o verbo "pintar".

Ao elaborar a reformulação, o sujeito "criou" uma árvore como tema para a pintura. Destacamos esta ocorrência no item que se refere às ocorrências envolvendo elementos icônicos, porque não podemos explicar essa interpretação a partir de elementos socioculturais e menos ainda com relação ao código, visto que, em momento algum, qualquer palavra do texto fez menção a nada que pudesse remeter à ideia de uma árvore.

O mais curioso é que ao relatar a estória, G2-UN-001 interpreta as imagens com coerência e compreende a situação global da tirinha.

\subsection{Identificação dos personagens}

As ocorrências envolvendo interferência das imagens na identificação dos personagens não comprometeram, de forma alguma, a compreensão global da narrativa. Com relação a este aspecto, o relato do sujeito G2-EM-001 não nos possibilitou verificar esta questão por ter repetido as falas, como havia feito na reformulação.

Os 10 sujeitos restantes (G2-EM-003, G2-EM-008, G2-EM-011, G2-EM-014, G2-EM-025, G2EM-022, G2-UN-001, G2-UN-002, G2-UN-003 e G2-UN-010) identificaram a presença dos três personagens e o autor do enunciado ¿Y si pintamos una bailarina?.

\subsubsection{Ocorrências relacionadas a elementos socioculturais na Tirinha 2}

Acreditamos que a construção do efeito de sentido tem como principal fator os elementos socioculturais que são explicitados nos relatos dos sujeitos informantes. Identificamos três construções importantes:

\subsection{Efeito de sentido de SUGESTÃO}

Dos 19 sujeitos informantes, 11 compreenderam que o enunciado ¿Y si pintamos una bailarina? constitui uma sugestão, corroborando com nossas análises, apresentadas no final do Capítulo 2. 
Os sujeitos G2-EM-003, G2-EM-008 e G2-UN-008 apresentam essa compreensão explicitamente:

G2-EM-003 [...] O garoto sugere uma bailarina e o cachorro um modelo $[\ldots]$

G2-EM-008 [...]Batu sugere que pintem uma bailarina[...]

G2-UN-008 [...]Sem saber o que pintar ela sugere ao cão para que eles pintassem uma bailarina[...]

Os demais, G2-EM-009, G2-EM-018, G2-EM-022, G2-EM-023, G2-EM-025, G2-UN-001, G2-UN002 e G2-UN-003 apresentam esta construção sob a forma de ter uma ideia:

G2-EM-009 Um menino tem a ideia de pintar uma bailarina $[\ldots]$

G2-EM-018 [...]Então ela tem a ideia de pintar uma bailarina[...]

G2-EM-022 Um menino e seu cão queriam pintar algo e o menino deu a ideia de pintarem uma bailarina[...]

G2-EM-023 A garota ruiva quer pintar algo mas ainda não tem ideia. Penso em pintar uma bailarina[...]

G2-EM-025 [...]Batu junto com seu cachorro azul onde ele quer pinta e tem uma ideia de pintar uma bailarina[...]

G2-UN-001 [...]Então tiveram a ideia de pintar uma bailarina[...]

G2-UN-002 [...]Então o garoto dá a ideia de pintarem uma bailarina[...]

G2-UN-003 [...]Batú deu ideia de pintar uma bailarina.[...]

\subsection{Efeito de sentido de DECISÃO}

Diferentemente da maioria dos informantes e de nossa análise, três sujeitos tiveram a compreensão de que Batu tomou a decisão de pintar uma bailarina:

G2-EM-014 Batu, juntamente com seu cão pensa em fazer uma pintura qualquer. Ele resolve então desenhar uma bailarina $[\ldots]$ 
G2-EM-011 Um menino e um cachorro azul com dúvidas em que ele poderia pintar, ele decide pintar uma bailarina $[\ldots]$

G2-UN-006 A menina estava sem ideias do que pintar, aí ela

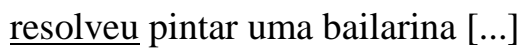

\subsection{Efeito de sentido de ACORDO}

O sujeito G2-UN-010 compreendeu que o diálogo entre Batu e Tútum se tratava de uma conversa para decidir o que iriam pintar. Nesta construção, a decisão não foi só de Batu. Houve um acordo, fruto de uma negociação:

G2-UN-010 A tirinha fala sobre um garoto e seu cãozinho, que estavam brincando de pintores; mas antes de começarem a brincadeira conversaram para decidir o que iriam pintar.

Após a conversa, decidiram que fariam a pintura de uma bailarina. [...]

\subsection{Efeitos de sentidos não explicitados}

Em quatro relatos não foi possível identificar qual foi a construção de sentido dos sujeitos, seja por terem sido feitos com a reprodução das falas (G2-EM-001), seja por ter sido um relato bastante sintético (G2-EM-013, G2-EM-027 e G2-EM-029) que não explicita qual foi a compreensão do sujeito com relação à situação apresentada:

G2-EM-001

_O que podemos pintar

_não sei

_E se pintarmos uma bailarina

_Isso. Espera não teriamos que ter uma modelo

_Certo, espera quem poderia ser

_falta muito ia

G2-EM-013__ _ que podemos pintar?

_Não sei

E se pintarmos uma bailarina?

_Ok mas, não teriamos que ter um modelo?

_Certo... mas, quem poderia ser?

_Falta muito, tempo?

G2-EM-027

_O que podemos pintar

_Não sei

_E se pintarmos uma bailarina

_OK precisamos de uma modelo

_Certo... OK quem poderia ser

_Falta muito ai
O que podemos pintar, não sei e se pintarmos uma bailarina? Isso espera não teriamos que ter um modelo

Certo espera quem poderia ser falta muito ai.

Esse quadrinho é uma menina e um cachorro pintando em um quadro um menino vestido de bailarina.

Uma moça que tenta fazer uma pintura de uma bailarina. 
G2-EM-029

_O que podemos pintar?

_Não sei

_E se pintarmos uma bailarina?

_Calma... Não teriamos que ter um modelo

_Certo... quem poderia ser?

_Falta muito
Que uma menina quer fazer uma pintura e precisava de um molde.

3.2.2.2.5 Cruzamento entre as ocorrências de elementos icônicos e o efeito de sentido explicitado pelos sujeitos informantes na Tirinha 2

Em seguida, apresentamos no quadro da sequência um cruzamento entre as ocorrências relacionadas ao elemento icônico, com relação à identificação dos personagens e o efeito de sentido que os sujeitos atribuíram ao enunciado em análise ¿Y si pintamos una bailarina?

\begin{tabular}{|c|c|c|c|c|}
\hline \multicolumn{5}{|c|}{ Quadro 8 - Construção de efeito de sentido versus elemento icônico na Tirinha 2} \\
\hline $\begin{array}{l}\text { Elemento } \\
\text { icônico } \\
\text { Efeito de } \\
\text { sentido }\end{array}$ & $\begin{array}{l}\text { Batu visto } \\
\text { como menina }\end{array}$ & $\begin{array}{c}\text { Identificação de } \\
\text { somente dois } \\
\text { personagens }\end{array}$ & $\begin{array}{c}\text { Não } \\
\text { identificação } \\
\text { dos } \\
\text { personagens }\end{array}$ & $\begin{array}{c}\text { Identificação } \\
\text { dos } \\
\text { personagens }\end{array}$ \\
\hline Sugestão & $\begin{array}{l}\text { G2-UN-008 } \\
\text { G2-EM-023 } \\
\text { G2-EM-018 }\end{array}$ & G2-EM-009 & & $\begin{array}{l}\text { G2-EM-003 } \\
\text { G2-EM-008 } \\
\text { G2-EM-022 } \\
\text { G2-EM-025 } \\
\text { G2-UN-001 } \\
\text { G2-UN-002 } \\
\text { G2-UN-003 }\end{array}$ \\
\hline Decisão & G2-UN-006 & & & $\begin{array}{l}\text { G2-EM-011 } \\
\text { G2-EM-014 }\end{array}$ \\
\hline $\begin{array}{c}\text { Acordo / } \\
\text { negociação }\end{array}$ & & & & G2-UN-010 \\
\hline Não identificado & $\begin{array}{l}\text { G2-EM-013 } \\
\text { G2-EM-027 } \\
\text { G2-EM-029 }\end{array}$ & & G2-EM-001 & \\
\hline
\end{tabular}

Dos 19 informantes, 11 compreenderam tratar-se de uma sugestão, independentemente de terem identificado corretamente os personagens. Três deles consideraram que Batu era uma menina e um deles (G2-EM-009) desconsiderou a presença de Tútum, personagem com quem Batu interagiu todo o tempo.

Por outra parte, G2-EM-011, G2-EM-014 e G2-UN-006, mesmo tendo identificado corretamente os três personagens, tiveram uma compreensão associada a uma tomada de decisão. 
Com base nessas ocorrências, podemos concluir que a identificação, correta ou não, dos personagens não teve influência na compreensão do efeito de sentido do enunciado como sugestão.

\subsubsection{Ocorrências relacionadas a elementos linguísticos da Tirinha 2}

\subsection{Questões modo-temporais da Tirinha 2}

Observamos o uso do infinitivo pessoal "pintarmos", na reformulação do enunciado ¿Y si pintamos una bailarina? por dezesseis sujeitos. Entre os três sujeitos restantes, G2-EM-014 e G2-UN-010 adotaram o pretérito do subjuntivo "pintássemos", além de uma outra opção para a reformulação da fala 1, do primeiro quadrinho ¿Qué podemos pintar? - o futuro simples do presente do Indicativo "poderemos" e o futuro do pretérito do Indicativo "poderíamos", respectivamente:

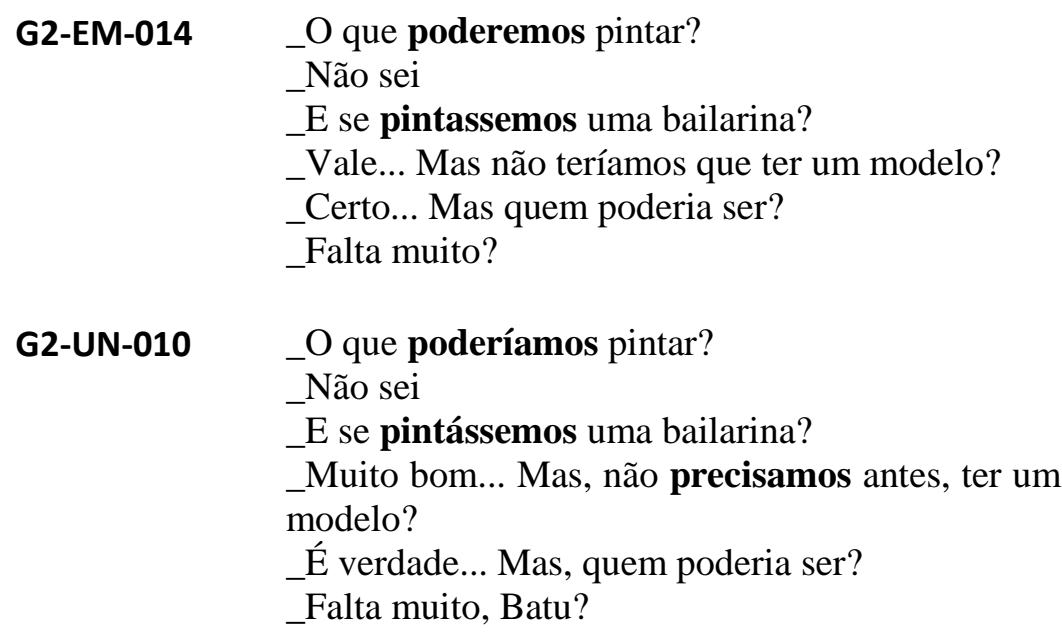

Este último sujeito apresenta, também, uma diferença na reformulação da fala 4, correspondente ao segundo quadrinho, ao adotar "mas não precisamos" no lugar de "mas não teríamos que ter", utilizado pela maioria dos sujeitos (treze). De qualquer forma, esta opção não altera o sentido de negociação presente na reformulação dos demais

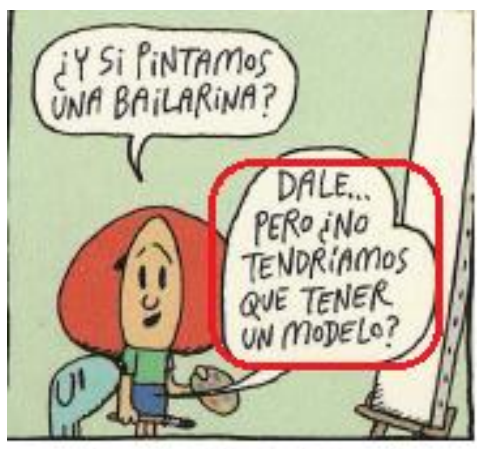

Quadrinhho 2 - fala 4

Destacamos o terceiro sujeito, G2-EM-025 que usou o presente de indicativo "si pintamos": 

G2-EM-025_Que podemos pintar?
_Não sei
_E si pintamos uma bailarina?
_Precisamos de um modelo?
_Certo Boris poderá ser?
_Falta muito, Batu?

Eu acabei de ler um menino ruivo chamado de Batu junto com seu cachorro azul onde ele quer pinta e tem uma ideia de pintar uma bailarina e chama seu amigo Boris para ser a Bailarina onde ele aceita o convite e o modelo de Batu.

Chamou nossa atenção o uso de uma estrutura mais próxima do espanhol original. Na fala 1, "o que podemos pintar" seria a forma mais usual do PB e na fala 3, "E si pintamos uma bailarina" manteve a conjunção em Espanhol.

Este sujeito chamou nossa atenção também pela adoção de outras formas modo-temporais que o diferenciaram dos demais. Na fala 4, a maioria dos sujeitos, com pequenas variações, reproduziu a estrutura "não teríamos que ter um modelo?", que pelo uso do futuro do pretérito imprime um sentido de negociação e cortesia. Adotando "precisamos de um modelo?", G2-EM-025 parece atribuir maior autoridade a Batu, colocando Tútum numa posição de consulta, deixando para Batu a decisão, mesmo que com uma modulação interrogativa: "Certo Boris poderá ser?". Nesta construção, a falta de pontuação complica nossa análise sobre qual teria sido sua compreensão. Acreditamos que faz mais sentido "Certo, Boris poderá ser?" e, neste caso, mais uma vez, o sujeito elabora uma construção pouco usual do PB, a qual seria: "Poderá ser o Boris?"

No relato, no entanto, o tom parece mais cortês e Batu faz um "convite" ao amigo.

\subsection{Tútum também fez uma sugestão}

Além de compreender o efeito de sentido de sugestão com relação ao enunciado ¿ $Y$ si pintamos una bailarina?, G2-EM-003, G2-UN-003 e G2-UN-008 atribuíram, também a Tútum a expressão de uma sugestão.

G2-EM-003 Um garoto ruivo e seu cachorro estão procurando e pensando no que poderão pintar. $\underline{\mathrm{O} \text { garoto }}$ sugere uma bailarina e o cachorro um modelo. $[\ldots]$

G2-UN-003 Batú quer saber o que ele e seu cãozinho azul tuntúm poderiam pintar. Seu cachorrinho não sabia. Batú deu ideia de pintar uma bailarina. E o tuntum deu ideia para os dois terem um modelo de bailarina $[. .$.

G2-UN-008 [...]Sem saber o que pintar ela sugere ao cão para que eles pintassem uma bailarina. $\underline{\mathrm{O} \text { cão sugere }}$ ter um modelo vivo.[...] 
Acreditamos que este efeito de sentido tenha sido construído devido ao uso do verbo no futuro do pretérito [teríamos] e à modulação interrogativa, na fala 4, do quadrinho 2.

\subsubsection{Algumas interpretações interessantes}

Assim como observamos nas análises da Tirinha 1, alguns sujeitos explicitaram outras interpretações que nos pareceram interessantes:

\subsection{Humor ou comicidade}

Os sujeitos G2-UN-006 e G2-UN-008 identificam um elemento cômico atribuído ao fato de haver um modelo masculino vestido de bailarina. G2-UN-006 declara que o esperado como modelo de uma bailarina seria uma mulher. G2-UN-008 relata ter lido uma "tirinha cômica" na qual "o amigo da menina se veste de bailarina". Destacamos que ambos os sujeitos são mulheres, estudantes universitários.

$\begin{array}{ll}\text { G2-UN-006 } & \text { A menina estava sem ideias do que pintar, aí ela } \\ & \text { resolveu pintar uma bailarina e para isso ela } \\ \text { queria (o cachorrinho deu a ideia de arrumar um } \\ \text { modelo) um modelo. No fim, ela acabava } \\ \text { arrumando um amigo para ser modelo. O amigo } \\ \text { dela fala se falta muito p/ pintar no último } \\ \text { quadrinho. O que provoca humor na tira é o fato } \\ \text { da modelo ser homem, sendo que o esperado era } \\ \text { para ser uma mulher. }\end{array}$

G2-UN-008 Acabo de ler uma tirinha cômica que se passa com uma menina e seu cão a pintar uma tela. Sem saber o que pintar ela sugere ao cão para que eles pintassem uma bailarina. O cão sugere ter um modelo vivo. Ela concorda e assim o amigo da menina se veste de bailarina.

Chamou nossa atenção uma forma peculiar de redação: "uma menina e seu cão a pintar uma tela". Esta é uma forma pouco usual no $\mathrm{PB}$, mais próxima do português de Portugal, o que denota, de certa forma, outros conhecimentos (neste caso da variedade de Portugal) que podem influir na maneira pela qual o sujeito se relaciona com a aprendizagem de uma nova língua.

\subsection{O desconforto de Boris}

Três sujeitos explicitaram que Boris não está confortável no papel de modelo de bailarina. G2EM-003 atribui o desconforto de Boris ao fato de ele ter que ficar imóvel por muito tempo "ele está bastante tempo parado". G2-UN-002 cita o desconforto com a situação, que poderia ser o fato de ele estar vestido de bailarina. Também G2-UN-010 entende que Boris não está "muito confortável na posição de um bailarino" e interpretou que Tútum escapa do papel de modelo ao sugerir "com esperteza" buscar um modelo. Esta "esperteza" permite afirmar que, na opinião do informante, o papel de modelo não era agradável já para Tútum. 
Fica claro que, devido a uma construção sociocultural, a situação de fazer o papel de modelo de uma bailarina, para "meninos", parece ser incômoda. Destacamos que, novamente, estes sujeitos são mulheres.

G2-EM-003 Um garoto ruivo e seu cachorro estão procurando e pensando no que poderão pintar. $\mathrm{O}$ garoto sugere uma bailarina e o cachorro um modelo. Então eles usam seu amigo como modelo e ele está bastante tempo parado.

G2-UN-002 Um garoto e seu cachorro queriam pintar alguma coisa. O garoto pergunta ao cachorro se ele tem alguma ideia e ele responde que não. Então o garoto dá a ideia de pintarem uma bailarina e o cachorro diz que que para isso eles precisariam de um modelo. O garoto pergunta quem poderia ser o modelo e, então, o modelo foi um outro menino que parecia estar desconfortável com a situação e que pergunta se ainda faltava muito para acabarem.

G2-UN-010 A tirinha fala sobre um garoto e seu cãozinho, que estavam brincando de pintores; mas antes de começarem a brincadeira conversaram para decidir o que iriam pintar.

Após a conversa, decidiram que fariam a pintura de uma bailarina.

O cãozinho, muito esperto, achou melhor que fizessem a pintura a partir de um modelo; como não sabiam quem poderia ajudá-los, contaram com o auxílio do amigo Boris, mas que não parecia muito confortável na posição de um bailarino.

\subsubsection{Resultados parciais referentes à Tirinha 2}

A forma interrogativa parece, para alguns sujeitos, uma forma de debater e entrar em acordo ou sugerir e para outros representa uma decisão previamente tomada, considerando, neste caso, a forma interrogativa como uma pergunta de retórica.

Oito informantes, dos19, identificaram Batu como uma menina ( 6 alunos de Ensino Médio e 2 estudantes universitários). Neste contexto, este fato não teve relevância, pois não altera a mensagem. Mas, fica evidente que o elemento icônico é mais relevante que o elemento verbal. Principalmente, se considerarmos que foram fornecidas informações prévias sobre os três personagens, aos informantes.

Não achamos possível, no entanto, delimitar o que pesa mais na compreensão, o código ou a imagem, o verbal ou o não verbal. Retomamos Borges (2001) quando afirma que a interpretação, seja do não verbal, ou do verbal, está relacionada à cultura do intérprete. Os 
cabelos longos de Batu, pertencerem ao universo feminino, ou uma modelo de bailarina ter que ser "uma menina" faz parte da construção social dos participantes. 


\section{CAPÍTULO 4 \\ Pressupostos teóricos e resultados da pesquisa}

"Compreender um enunciado não é somente referir-se a uma gramática e a um dicionário, é mobilizar saberes muito diversos, fazer hipóteses, raciocinar, construindo um contexto que não é um dado preestabelecido e estável. A própria ideia de um enunciado que possua um sentido fixo fora de contexto torna-se insustentável."

(Dominique Maingueneau, 2008, p.20)

"Pensar la organización significa reunir lo que está desglosado y compartimentado, pero no por dilución en lo global abstracto, sino en el vínculo vivo que conduce de lo global a lo local, incluye las retroacciones local/global, y produce la organización en esa dinámica propia que debemos reconstruir en el conocimiento. Enseñar a contextualizar el conocimiento en su realidad global/local en busca del conocimiento pertinente es una tarea fundamental de la reforma educativa. El resultado de reflexionar sobre la organización."

(Edgar Morin, 2008a, p.6)

\subsection{Introdução}

Neste último capítulo, apresentamos uma reflexão sobre o percurso desta pesquisa, iniciando pelas nossas questões iniciais, passando pelos conceitos e teorias à luz das quais construímos novos entendimentos e orientamos nossas análises, chegando a nossos resultados indiciais. Indiciais, porque os entendemos como instigadores de novos desafios e motivadores para uma continuidade, portanto inacabados.

\subsection{Nossa base conceitual}

Iniciamos este trabalho com a proposta de aprofundar nossa pesquisa realizada na IC, buscando identificar a influência (ou não) do contexto para a compreensão de enunciados compostos por Orações Condicionais, por falantes nativos de PB.

Ao longo deste percurso, fomos construindo um novo entendimento sobre estas estruturas e, mais especificamente, sobre a estrutura dos enunciados que elegemos para nossas análises. Discutimos a pertinência da classificação das orações utilizadas nos testes desta pesquisa, às quais, incialmente, batizamos Orações Condicionais não prototípicas, do ponto de vista de sua 
estrutura. No entanto, o que (não) encontramos nas gramáticas consultadas relacionado a definições e exemplos nos instigou a discutir sobre a pertinência de tal classificação.

A partir disso, antes de verificarmos a influência (ou não) do contexto para a compreensão, reorientamos nosso trajeto a fim de elucidar essa questão gramatical. Desconstruímos os enunciados e passamos a analisar a relação entre seus componentes - a introdução por $Y+s i$ e a modulação interrogativa.

\subsubsection{Que compreensão temos deste "Y SI"?}

\subsubsection{Sob uma perspectiva pragmática}

A introdução de um novo tema, pela partícula $Y$, segundo Escandel Vidal (1999), espera do interlocutor o aporte de uma informação a respeito. Nesse sentido, Montolío (1999) afirma que na estrutura condicional [se $p, q]$ há uma implicação pragmática entre os dois enunciados, visto que ao se deparar com a partícula SI o interlocutor terá que aceitar a suposição $p$ e, para além de interpretar $q$, terá que complementar a ideia do enunciador.

Sobre esta relação de construção mútua de sentido, estamos de acordo com Koch (2011) quando afirma que para esta somente uma abordagem sintático-semântica-pragmática poderá dar solução, "visto que o funcionamento global de uma língua só pode ser devidamente explicado por um estudo integrado dos três componentes" (p. 108).

\subsubsection{2 À luz da Teoria da argumentação}

A conjunção $Y$ interpretada enquanto conector argumentativo tem, na maioria das vezes, a função de vincular dois elementos do discurso, como coordenativa. No entanto, da forma como se apresenta nos enunciados que estamos analisando, deixa de ter a função de coordenação, no sentido lato, e adquire força argumentativa alterando a orientação argumentativa da conjunção $S I$ que, prototipicamente seria de condição. Neste caso, nos termos de Portolés (1988), a partícula $Y$ passaria à função de operador argumentativo.

De acordo com Portolés (1988, p. 80),

Un conector argumentativo consiste en una unidad que articula dos miembros del discurso, o más, que intervienen en una estrategia argumentativa única (v. gr. pero, sin embargo, además, etc.), y un operador argumentativo es una unidad que, aplicada a un contenido, transforma las potencialidades argumentativas de este contenido (v. gr. bien, casi, un poco, etc.). (grifos nossos)

A conjunção $S E / S I$ remete a uma construção de hipótese e a introdução do enunciado pela partícula $E / Y$ permite-nos entender que seu papel é o de ampliar a força argumentativa que ambos teriam, em separado. À luz da Teoria da Argumentação, entendemos a junção $[E$ se/ $Y$ si] com função de operador argumentativo. 


\subsubsection{3 À luz da semântica argumentativa}

Além de Bagno (2011), que apresenta um incômodo com relação às classificações estabelecidas e, de certa forma, cristalizadas nos estudos gramaticais, também encontramos em Koch (2011) voz para nosso questionamento quanto às classificações encontradas, nas gramáticas, aos conectores e conjunções tratados como operadores relacionais. $\mathrm{Na}$ opinião da autora, estes constituem operadores argumentativos ou discursivos, marcas linguísticas importantes da enunciação.

Considerar " $Y$ si" como operador argumentativo nos dá sustentação para afirmar que os enunciados que trouxemos para nossa análise não são Orações Condicionais sem apódose, nem pseudocondicionais ou mesmo orações hipotéticas. A partir daí, passamos a analisar estes enunciados como uma estratégia argumentativa.

\subsubsection{Tomando os enunciados em análise}

Entendemos que a partícula $\mathbf{Y}$ (elemento linguístico) articula os elementos não linguísticos do contexto, em cada uma das situações sociais dos personagens (brincadeiras):

(Tirinha 1) situação de perigo por estarem desarmados, frente a um ataque de piratas; (Tirinha 2) discussão em busca de um tema para a nova pintura

a uma nova proposição a seu interlocutor, introduzida pela partícula SI (hipótese):

(Tirinha 1) mudar de brincadeira

(Tirinha 2) pintar uma bailarina

Assim, concluímos que a junção $E$ se $/ \boldsymbol{Y}$ si constitui um operador argumentativo que altera a orientação argumentativa criando um efeito de sentido de proposição ou de sugestão.

\subsubsection{Qual efeito de sentido atribuímos à modulação interrogativa?}

\subsubsection{Quanto à modulação interrogativa}

Haimann (1978), citado por Montolío (1999, p. 66-67), identifica uma semelhança entre prótases condicionais e orações interrogativas, "ya que tanto en unas como en otras el hablante pretende que el oyente acepte el contenido como 'dado'".

Aliado à forma interrogativa, identificamos que os enunciados em análise apresentam uma estratégia argumentativa que visa à cortesia como uma maneira de atenuar alternativas assertivas.

\subsubsection{Y si isto for uma forma de cortesia?}

Segundo Briz (2013, p.284) a atenuação é o lado linguístico da manifestação de cortesia. 
A atenuação é uma categoria pragmática, um mecanismo estratégico e tático (portanto, intencional), que se relaciona à efetividade e à eficácia do discurso, ao alcance dos objetivos na interação, além de se tratar de uma função só determinável a partir do contexto.

Nos termos de van Dijk (2007, 2012), é o contexto que fornece, ao enunciador, elementos para a elaboração mental da situação comunicativa, bem como da receptividade de seu interlocutor, a fim de produzir o efeito de sentido que viabiliza atingir seu objetivo discursivo.

Assim, concluímos que nas tirinhas em análise, os enunciados apresentam uma proposição ou sugestão para uma nova brincadeira (Tirinha 1) e um tema para a pintura (Tirinha 2). Entendemos que os enunciadores (Boris e Batu, respectivamente) utilizam uma forma atenuadora em busca de adesão à sua ideia.

\subsection{Objetivos e perguntas de pesquisa}

Considerando a presença de todos estes elementos - uma Oração Condicional não prototípica, sem apódose, introduzida pela partícula $Y$, na forma interrogativa e os efeitos possíveis apontados por Montolío (1999) e Escandell Vidal (1999), buscamos evidenciar de que forma os componentes do contexto e a instrução formal poderiam (ou não) influenciar na compreensão deste tipo de enunciado, já que os testes foram aplicados em aprendizes de ELE, independentemente de estes já terem recebido, ou não, instrução formal sobre Orações Condicionais.

A partir da (des/re)construção dos enunciados ¿Y si jugamos a otra cosa? / ¿Y si pintamos una bailarina?, e de nossas conclusões preliminares sobre tal estrutura e seus efeitos de sentido, as seguintes questões nos moveram no desenvolvimento deste trabalho:

a) Para além das questões sistêmico-formais da língua espanhola, há influência de elementos discursivo-pragmáticos no eixo produção-compreensão;

b) O que está influenciando na compreensão? De que se compõe o contexto que ajuda ou atrapalha na compreensão?;

c) De que forma o contexto e a instrução formal podem (ou não) influenciar na compreensão deste tipo de enunciado?;

d) Como consequência da instrução formal sobre as Orações Condicionais, com foco na metalinguagem, o que irá pesar mais na compreensão do aprendiz, a formalização dessas formas, o contexto, ambos ou, ainda, nenhum deles, já que, segundo analisamos anteriormente, os enunciados dos testes não se tratam de Orações Condicionais?

Descrevemos, em seguida, as respostas que obtivemos para cada uma delas. 


\subsubsection{A influência de elementos discursivo-pragmáticos no eixo produção-compreensão}

A reformulação dos enunciados, em português, referente à Atividade 1, solicitada aos sujeitos de pesquisa, teve por objetivo verificar sua compreensão da situação e, de acordo com a forma ou recurso linguístico utilizado, checar se houve a influência ou não da LM ou ainda do conhecimento de outras línguas na sua elaboração.

Na Atividade 2, o relato da situação representada, em português, permitiu evidenciar quais foram os elementos discursivo-pragmáticos que interferiram na compreensão da enunciação, sob a influência (ou não) dos elementos do contexto.

Nos termos de Parret (1985), a compreensão "cria" um contexto que influencia na compreensão, em um movimento de ida e volta, tal como ocorre no eixo produçãocompreensão (BRUNO, 2006), em que o aluno testa hipóteses com base em seus conhecimentos prévios e nesse processamento vai elaborando sua compreensão.

Por essa razão, analisamos as respostas da Atividade 1 (reformulação das falas dos personagens) e da Atividade 2 (relato) de forma cruzada, a fim de identificar se houve compreensão ou não e qual foi o efeito de sentido construído pelo informante.

Foi possível verificar que na Atividade 2, os relatos dos sujeitos apresentaram algumas ocorrências relacionadas, principalmente, aos elementos icônicos. Algo esperado, visto estarmos tratando de um suporte narrativo que envolve uma dupla articulação de linguagem verbal e não verbal.

Identificamos algumas diferenças observadas no eixo produção-compreensão entre a reformulação e o relato que atribuímos à proximidade entre as línguas, principalmente, no Grupo 1, cuja tirinha trazia [jugar a] que, para alguns sujeitos foi como uma "armadilha", que contribuiu para confundi-los quanto a seu significado. Mas os elementos para a contextualização foram suficientes para que os sujeitos criassem a totalidade do contexto de forma eficaz e compreendessem o efeito de sentido de sugestão.

\subsubsection{Os componentes do contexto e sua influência na compreensão}

A partir dos pressupostos teóricos e reflexões de Parret (1985), Ibañez (1990) e van Dijk (2007, 2012), retomamos que entendemos contexto como uma construção mental elaborada pelos interlocutores em um processo recursivo e retroativo, que se dá a partir da combinação de componentes verbais (elementos linguísticos, aos quais associamos o código textual e as relações sintáticas e discursivo-pragmáticas) e não verbais (conhecimentos prévios, compartilhados ou não, relacionados a elementos socioculturais e icônicos) presentes em uma situação social específica que os participantes, inconscientemente selecionam, de acordo com a relevância que tenham para aquela situação, para a sua compreensão e produção discursiva, em decorrência de sua compreensão sobre a situação comunicativa, conforme apresentamos no Quadro 3: Componentes do contexto. 
Evidenciamos que o falante se apropria de informações novas aliadas a conhecimentos que traz na bagagem ('dispositivo-k', de van Dijk, 2007) para a elaboração do modelo de contexto adequado a aquela situação de comunicação.

A partir das análises dos dados, identificamos que a brincadeira (Tirinha 1), constituinte de um imaginário que faz parte da construção social e cultural dos sujeitos, aliada ao co-texto, permitiu-Ihes elaborar o contexto situacional, nos termos de Parret (1985), compreender a estória e construir um efeito de sentido de sugestão.

Também foi este o efeito de sentido construído pelos sujeitos que trabalharam com a Tirinha 2 , ainda que os cabelos longos de Batu tenham causado alguma "confusão" fazendo com que alguns informantes interpretassem que o personagem era uma menina, dando destaque ao elemento icônico em detrimento do elemento verbal. Mas esta ocorrência não teve influência na compreensão.

Diante das respostas dos sujeitos, não consideramos possível delimitar o que pesa mais na compreensão, o código ou a imagem, o verbal ou o não verbal. Concordamos com Borges (2001) quando afirma que a interpretação, seja do não verbal, ou do verbal, está relacionada à cultura do intérprete. Acreditamos, sim, que este - o elemento sociocultural - seja o elemento constituinte do contexto de maior influência para a compreensão, já que, para o caso das Tirinhas, é preciso que se ativem conhecimentos sobre brincadeiras e também de diferentes elementos que a constituem ou não como, por exemplo, saber diferenciar entre um chapéu e um quepe.

\subsubsection{O que os dados revelaram sobre a compreensão}

Foi possível evidenciar que os informantes compreenderam sim, o efeito de sentido dos enunciados destacados nas tirinhas. Ainda que o co-texto tenha causado algum tipo de ambiguidade, considerando a suposta transparência entre o Espanhol e o PB, é possível afirmar que os diferentes elementos do contexto possibilitaram a compreensão global da estória.

Além do elemento cultural ou conhecimento pragmático - nos termos de Parret (1985) e van Dijk (2007), o conhecimento de mundo advém de experiências e vivências. Assim, é possível considerar que a maturidade intelectual (são dois grupos de informantes: alunos de Ensino Médio - entre 15 e 18 anos, e universitários em nível de pós-graduação) tem alguma influência. No Grupo 1, a compreensão de Boris ser o capitão ocorreu para seis informantes, dos quais, quatro são estudantes de Ensino Médio. No Grupo 2, dos oito informantes que interpretaram que Batu era uma menina, seis são alunos do Ensino Médio.

Por outro lado, com relação ao preconceito sobre o "papel do homem", quando Boris faz o papel de modelo de bailarina, na Tirinha 2 , dos cinco informantes que manifestaram essa posição, quatro pertencem à categoria de universitários. 


\subsubsection{Quanto à instrução formal}

Quanto à instrução formal, concluímos que esta não teve qualquer influência na compreensão ou no processo. No entanto, chamamos a atenção para o fato de que esta, normalmente, reproduz classificações gramaticais "enquadradas" e, tratando-se de estruturas complexas, como estas que utilizamos em nossos testes, demandam uma mudança de paradigma no sentido de rever a organização linear de conteúdos curriculares.

Para além do viés discursivo-pragmático, essa observação nos leva ao questionamento que vimos apresentando com relação ao tratamento dado, em alguns casos, a esses conteúdos na instrução formal que, normalmente, reproduz classificações gramaticais sem reflexão. Para um aprendiz de Espanhol, falante do PB, a proximidade entre as línguas pode se constituir uma armadilha de diferente ordem. O que dizer, então, de estruturas morfossintáticas mais complexas e, no entanto, aparentemente, idênticas por sua organização estrutural?

A segmentação e a fragmentação de conteúdos, no ensino de E-LE, comprometem o processo dos alunos em direção à língua-alvo, este mediado pela produção e compreensão, conforme Bruno (2006, p. 152). Defendemos, portanto, que conscientizar os usuários da língua do valor argumentativo de marcas linguísticas como as que compõem os enunciados analisados possibilita percebê-las no discurso do outro e utilizá-las, com eficácia, no seu próprio, segundo Koch (2011).

Deixamos aqui a proposição de uma revisão sobre a organização de conteúdos e a consequente fragmentação dos objetos de ensino, na instrução formal, principalmente no caso de cursos de formação de professores, à luz dos princípios sistêmico-organizacional, dialógico, de recursividade e retroatividade, do Pensamento Complexo de Edgar Morin (2003, 2006), os quais permearam nossas reflexões ao longo desta pesquisa.

\section{4 À guisa de conclusão}

Iniciamos este trabalho com um objetivo aparentemente simples: verificar a influência (ou não) do contexto para a compreensão de Orações Condicionais. Mas, nas palavras de Bachelard, citado por Morin (2006, p.15) “o simples não existe, só o que há é o simplificado".

Assim, no percurso desta pesquisa nos deparamos com "descobertas" que reforçam e comprovam essa afirmação. O homem tende a tratar de forma simplificada questões que são complexas, buscando uma organização que falsamente, propicia uma facilidade. Neste processo, tenta-se definir o todo pela soma das partes, o que leva à fragmentação e ao "encaixotamento".

Do ponto de vista sistêmico-organizacional, nos termos de Morin (2003), as partes possuem qualidades próprias, mas que sofrem influências por fazerem parte do todo. Entendemos que assim construíram o conhecimento, fonte da qual nos servimos nesta pesquisa, Portolés (1998), quando faz uma distinção entre o conector argumentativo e operador argumentativo 
ao destacar a mudança de função de uma partícula de acordo como ela afeta o conteúdo; Koch (2011), em sua defesa pela indissociabilidade dos componentes semântico, sintático e pragmático para o funcionamento global da língua; Parret (1985), Ibañez (1990) e van Dijk (2007) ao entender o contexto como um sistema dinâmico que se retroalimenta dos componentes verbais e não verbais.

Acreditamos que ao desenvolver os conteúdos e recursos da língua alvo de forma a tornar consciente seu uso pelos aprendizes, estes passam a percebê-los e compreendê-los no discurso do outro e a utilizá-los, com eficácia, no seu próprio. Assim, reforçamos nosso questionamento com relação ao tratamento dado, em alguns casos, a esses conteúdos na instrução formal que, normalmente, reproduz classificações gramaticais sem reflexão.

Defendemos que o ensino deve-se desenvolver de forma dialógica, assim como o processo dialógico que se observa no eixo produção-compreensão, nos termos propostos por Bruno (2006) com base no Pensamento Complexo. Segundo Morin (2003, p. 36) “o princípio dialógico pode ser definido como associação complexa (complementar, concorrente, antagônica) de instâncias necessárias, conjuntamente necessárias à existência, ao funcionamento e ao desenvolvimento de um fenômeno organizado", valendo à pena reforçar que à luz da Complexidade "organizado" não significa de modo linear.

Nesse sentido, podemos interpretar que a escola é formada por uma multiplicidade organizacional constituída pelo professor, pelo aluno e pelo processo de ensino e aprendizagem que, por sua vez, dependem desta (auto)organização dialógica, enquanto constituintes da própria escola.

Consideramos que, mais que ter alcançado os objetivos propostos, o maior e mais importante resultado deste trabalho foi termos desenvolvido uma forma de pensar complexa que, por outro lado, poderá vir a trazer luzes para "provocar" outros trabalhos, não só na área dos estudos descritivos sobre o par PB/E, mas também sobre questões relativas à aquisição, ao ensino e à aprendizagem dessas línguas e quem sabe de outras. 


\section{BIBLIOGRAFIA}

Referências bibliográficas

BALLESTEROS, M. A. C. Aprendendo mais que gramática: como os futuros professores de Espanhol percebem os elementos pragmático-discursivos em Orações Condicionais em Espanhol. Revista (Entre Parênteses), vol. 1, num. 5, 2016.

BAGNO, M. (1961) Gramática pedagógica do português brasileiro. São Paulo: Parábola Editorial, 2011.

BORGES, L. R. Quadrinhos: literatura gráfico-visual. In: Agaquê - Revista eletrônica especializada em Histórias em Quadrinhos e temas correlatos. São Paulo: Escola de Comunicações e Artes da USP, v.3, n.2, agosto/2001. Disponível em: http://www.eca.usp.br/nucleos/nphqeca/agaque/indiceagaque.htm. Acesso em outubro de 2018.

BRIZ, A. A atenuação e os atenuadores: estratégia e táticas. Versão para o português: Luiz Antônio da Silva, Adriana Marcelle de Andrade e Ramiro Carlos Humberto Caggiano Blanco. Linha d'água. n. 26 (2), p. 281-314, 2013.

BRUNO, F. T. C. Ensino de espanhol: construção da impessoalidade em sala de aula. São Carlos: Claraluz, 2004. (Coleção interinvenção).

. Lo que uno/una comprende, lo que uno/una dice - Compreensão e produção do espanhol como língua estrangeira por adultos brasileiros em situação de ensino $e$ aprendizagem. Tese de Doutorado, DL - FFLCH/USP, 2006.

. O livro didático e a reforma do pensamento. In: BARROS, C; COSTA, E.; FREITAS, L. (orgs.). O livro didático de espanhol na escola brasileira. Campinas, SP: Pontes Editores, 2018, p. 387-404.

CASTILHO, A. T. Nova gramática do português brasileiro. São Paulo: Contexto, 2014.

CHARAUDEAU, P. \& MAINGUENEAU, D. Dicionário de Análise do Discurso. Trad. Fabiana Komesu, 3a ed., 2a reimpr., São Paulo: Contexto, 2016.

ESCANDELL VIDAL, M. V. Los enunciados interrogativos. Aspectos semánticos y pragmáticos. In: BOSQUE, I. y DEMONTE, V. (org). Gramática Descriptiva de la Lengua Española - entre la oración y el discurso/morfología. Madrid: Espasa Calpe S.A., 1999, p.3929.

FAUCONNIER, G. Espaces mentaux: aspects de la construction du sens dans les langues naturelles. Paris: Les Éditions de Minuit. Edição em inglês: Mental spaces. Cambridge: MIT Press, 1985. Disponível em: http://terpconnect.umd.edu/ israel/FauconnierMentalSpaces.pdf. Acesso em setembro de 2016.

FERNÁNDEZ LANZA, S. Una propuesta metodológica para la evaluación de condicionales. Revista de Filosofía, n. 2, vol. 33, p. 67-86, 2008. 
FIEDLER-FERRARA, N.O pensar complexo: construção de um novo paradigma. In: SIMPÓSIO NACIONAL DE ENSINO DE FÍSICA, 15. 2003, Curitiba. Atas do XV Simpósio Nacional de Ensino de Física. Curitiba: CEFET-PR, 2003. p. 1779-1789. 1CD-ROM.

GALISSON, R. \& COSTE, D. (concepção, coordenação e revisão) Dicionário de didáctica das línguas. Coimbra: Livraria Almedina, 1983.

GARCÍA, O. M. Comunicação em prosa moderna: aprenda a escrever, aprendendo a pensar. 26a ed., Rio de Janeiro: Editora FGV, 2006.

GONZÁLEZ, N. T. M. Quantas caras tem a transferência? Os clíticos no processo de ensino/aprendizagem do Espanhol/Língua Estrangeira. In: BRUNO, F. T. C. (org.). Ensino e aprendizagem de línguas estrangeiras: reflexão e prática. São Carlos: Claraluz, 2005, p. 55-70.

HILGERT, J. G. A cortesia no monitoramento de problemas de compreensão na fala. Em: PRETI, D. (org.) Cortesia verbal. São Paulo: Humanitas, 2008, p. 125-155.

IBAÑEZ, R. El contexto del evento verbal. IX Congresso Internacional da ALFAL, São Paulo: Unicamp, 1990.

JOLY, M. Introdução à análise da Imagem. Lisboa: Editora 70, 1994-2007.

JULIÁN MARISCAL, O. Las pseudocondicionales. Intento de clasificación. Interlingüística, n.17, p. 570-579, 2007.

KOCH, I. G. V. Argumentação e Linguagem. 13a ed., São Paulo: Cortez, 2011.

MAINGUENEAU, D. Os termos-chave da Análise do Discurso. Trad. Maria Adelaide P.P. Coelho da Silva. Lisboa: Gradiva Produções Ltda., 1997.

Análise de textos de comunicação. 5a ed., São Paulo: Cortez, 2008.

MARCUSCHI, L. A. Exercícios de compreensão ou copiação nos manuais de ensino de língua? In: Em aberto. Brasília, ano 16, n. 69, pp. 64-82, jan-mar/1996.

MATTE BON, F. Gramática Comunicativa del español: de la idea a la lengua - tomo II. 2a ed. 13a reimpr, España: EDELSA Grupo Didascalia, 1995.

MONTOLÍO, E. Las construcciones condicionales. In: BOSQUE, I. y DEMONTE, V. (org). Gramática Descriptiva de la Lengua Española - entre la oración y el discurso/morfología. Madrid: Espasa Calpe S.A., 1999, p.3643.

MOURA NEVES, M. H. Gramática de usos do Português. São Paulo: Editora UNESP, 2000.

MORIN, E. Ciência com consciência. Trad. Maria D. Alexandre e Maria Alice Sampaio Dória. 2aㅡ ed. Rio de Janeiro. Bertrand Brasil, 1998.

Educar na era planetária: o pensamento complexo como método de aprendizagem no erro e na incerteza humana. Trad. Sandra Trabucco Valenzuela. São Paulo: Cortez, Brasília-DF: UNESCO, 2003. 
. Introdução ao pensamento complexo. Trad. Eliane Lisboa. Porto Alegre: Sulina, 2006.

$\frac{}{\text { p.4-9. }}$. Reformar la educación, la enseñanza, el pensamiento. Este país, n. 202, ene/2008a,

MORIN, E.; ALMEIDA, M. C.; CARVALHO, E. A. (orgs.). Edgar Morin. Educação e complexidade: os sete saberes e outros ensaios. Tradução Edgard de Assis Carvalho. 5a ed. São Paulo: Cortez, 2009.

PARRET, H. Pragmática. In: Caderno de Estudos Linguísticos. Campinas: IEL/Unicamp, v.7, 1984, p.39-51.

. Contexto como restrições da compreensão em uma situação de diálogo. Cadernos de Estudos Linguísticos, n. 9, 1985, p. 159-169.

PERINI, M. Gramática do português brasileiro. São Paulo: Parábola Editorial, (1943) 2010.

PORTOLÉS, J. La teoría de la argumentación en la lengua y los marcadores del discurso. In: MARTÍN ZORRAQUINO, M. A.; MONTOLÍO DURÁN, E. (coordinadoras). Los marcadores del discurso - Teoría y análisis. Madrid: Arco Libros, 1988, p. 71-91.

POSSENTI, S. Por que (não) ensinar gramatica na escola. 16a reimpr. Campinas, SP: Mercado das Letras, 1996-2006

. Os limites do discurso: ensaios sobre discurso e sujeito. São Paulo: Parábola, 2009.

RAE - REAL ACADEMIA ESPAÑOLA. Oraciones complejas (VII-Concesivas y condicionales). In: Gramática de la lengua española. Madrid: Espasa Calpe S.A., 1999, p.373-383.

Construcciones condicionales y concesivas. In: Nueva gramática de la lengua española. Madrid: Espasa, 2010, p.897-915.

Diccionario panhispánico de dudas (DPD). Versão eletrônica. Disponível em: http://lema.rae.es/dpd/. Acesso em junho de 2016.

ROSA, J. G. Grande sertão: veredas. 19a ed. Rio de Janeiro, Nova Fronteira, 2001.

SANDES, E. I. A. O infinitivo flexionado no processo de aprendizagem do Espanhol como L2. Todas as Letras. n.3, p. 37-44, 2001.

SANTOS, B. S. Um discurso sobre as ciências na transição para uma ciência pós-moderna. São Paulo: Cortez, 2003.

SPERBER, D. \& WILSON, D. La comunicación. In: La relevancia: comunicación y procesos cognitivos. Madrid: Visor Dis. S. A., 1994a.

. La relevancia. In: . La relevancia: comunicación y procesos cognitivos. Madrid: Visor Dis. S. A., $1994 b$.

TUTE. Batu. Buenos Aires: Sudamericana, 2009. 
VAN DIJK, T. A. Coments on Context and Conversation. In: FAIRCLOUGH, N., CORTESE, G. \& ARDIZZONE, P. (Eds). Discourse and Contemporary Social Change. Bern: Peter Lang, 2007, p. 281- 316.

. Discurso e contexto: uma abordagem sociocognitiva. Trad. Rodolfo llari. São Paulo: Contexto, 2012.

VYGOTSKY, L. S. Pensamento e Linguagem. Tradução de Jefferson Luiz Camargo. Revisão técnica José Cipolla Neto. 4a ed., São Paulo: Martins Fontes, 2008.

Bibliografia de apoio

BITTENCOURT, D. L. R. A condicional hipotética e a modalidade: uma inter-relação dialógica. Cadernos do IL. Porto Alegre, n. 44, junho, 2012, p. 75-96.

BRAVO, D. y BRIZ, A. (eds.). Pragmática sociocultural: estudios sobre el discurso de cortesía en español. Barcelona: Editorial Ariel S.A., 2004.

CONTRERAS, L. Oraciones independientes introducidas por si. Boletín de Filología de la Universidad de Chile, n. 12, p. 273-290, 1963.

. Las oraciones condicionales. Boletín de Filología de la Universidad de Chile, n. 15, p. 33-109, 1966.

"Si" en oraciones y cláusulas interrogativas indagativas. Boletín de Filología de la Universidad de Chile, n. 34, p. 63-82, 1994.

DURANTI, A. \& GOODWIN, C. Rethinking context. Language as interactive phenomenon. Cambridge: University Press, 1992.

ESCANDELL VIDAL, M. V. Los fenômenos de interferência pragmática. MarcoELE: Revista de Didáctica, $\quad$ n. 9, p.95-110, 2009. Disponível em: http://marcoele.com/descargas/expolingua1996_escandell.pdf. Acesso em maio de 2016.

GERALDI, J. W. Se a semântica fosse pragmática... ou Para uma análise semântica dos enunciados condicionais. Dissertação de Mestrado, IEL/Unicamp, 1978.

KINTSCH, W. \& VAN DIJK, T. A. Strategies of discourse comprehension. San Diego, California, Academic Press, 1983.

KULILOWSKI, M. Z. \& GONZÁLEZ, N. T. M. Español para brasileños. Sobre por dónde determinar la justa medida de una cercanía. Anuario brasileño de estúdios hispánicos, n. 9, p. 11-19, 1999.

MARCUSCHI, L. A . Da fala para a escrita: atividades de retextualização. 2. ed., São Paulo: Cortez, 2001.

MORIN, E. Epistemologia da complexidade. In: SCHINITMAN, D. F. Novos paradigmas, cultura e subjetividade. Porto Alegre: Artes Médicas, 1996. P. 274-286. 
A cabeça bem-feita: repensar e reforma, reformar o pensamento. Tradução Eloá Jacobina. 15a ed. Rio de janeiro: Bertrand Brasil, 2008b.

NARBONA JIMÉNEZ, A. Las subordinadas adverbiales impropias en español (Bases para su estudio). Málaga: Librería Ágora, 1989.

- Las subordinadas adverbiales impropias en español (II). Causales y finales, comparativas y consecutivas, condicionales y concesivas. Málaga: Librería Ágora, 1990.

PERELMAN, C. \& OLBRECHTS-TYTECA, L. Tratado de la argumentación. La nueva retórica. Madrid: Editorial Gredós, 1989.

PORCAR MIRALLES, M. La oración condicional. La evolución de los esquemas verbales condicionales desde el latín hasta el español actual. Castellón, Universidad Jaume I, 1993.

SANTANA MARRERO, J. Si como marcador discursivo en el habla urbana de Sevilla. Interlingüística, n.7 (Actas del XI Encuentro de la Asociación de Jóvenes Lingüistas). Madrid, 1999, p. 211-216.

Las oraciones condicionales: Estudio en la lengua hablada. Sociolingüística Andaluza, n.13. Sevilla, Servicio de Publicaciones de la Universidad de Sevilla, 2003.

SANTOS, A. Complexidade e transdisciplinaridade em educação: cinco princípios para resgatar o elo perdido. Revista Brasileira de Educação, v. 13, n. 37, jan./abr. 2008, 71-83.

SPERBER, D. \& WILSON, D. La relevancia: comunicación y procesos cognitivos. Madrid: Visor Dis. S. A., 1994.

VAN DIJK, T. A. La ciencia del texto. Barcelona, Paidós, 1978

Modelos na memória - o papel das representações da situação no processamento do discurso. In: . Discurso, cognição e leitura. São Paulo, Contexto, 1988, p. 158-181.

VATRICAN, A. El condicional de cortesía en español: la hipótesis como forma de atenuación. Estudios de lingüística: investigaciones, propuestas y aplicaciones. Universitat de València, p. 469-480, 2013.2 Disponível em: http://www.uv.es/canea/archivos/Estudios linguistica 2013.pdf. Acesso em outubro de 2016. 


\section{APÊNDICE \\ Atividades - Quadros}

Atividades para composição do corpus

Atividades da Tirinha 1

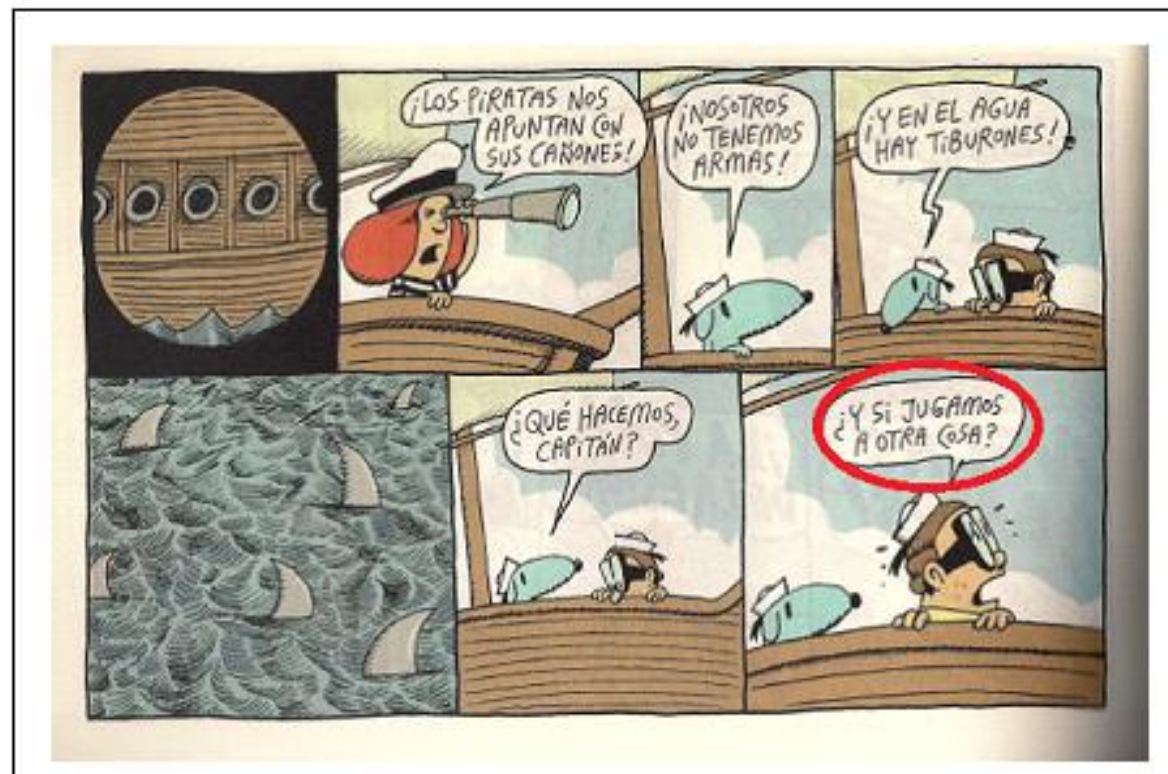

Escreva, em português, uma versão de cada uma das falas dos personagens da tirinha:

1) ¡Lospiratas nos apuntan con sus cañones!

2) ¡Nosotros no tenemos armas!

3) iY en el agua hay tiburones!

4) ¿Qué hacemos, capitán?

5) ¿Ysi jugamos a otra cosa?

Relate, em português, o que você a ca ba de ler. 
Atividades da Tirinha 2

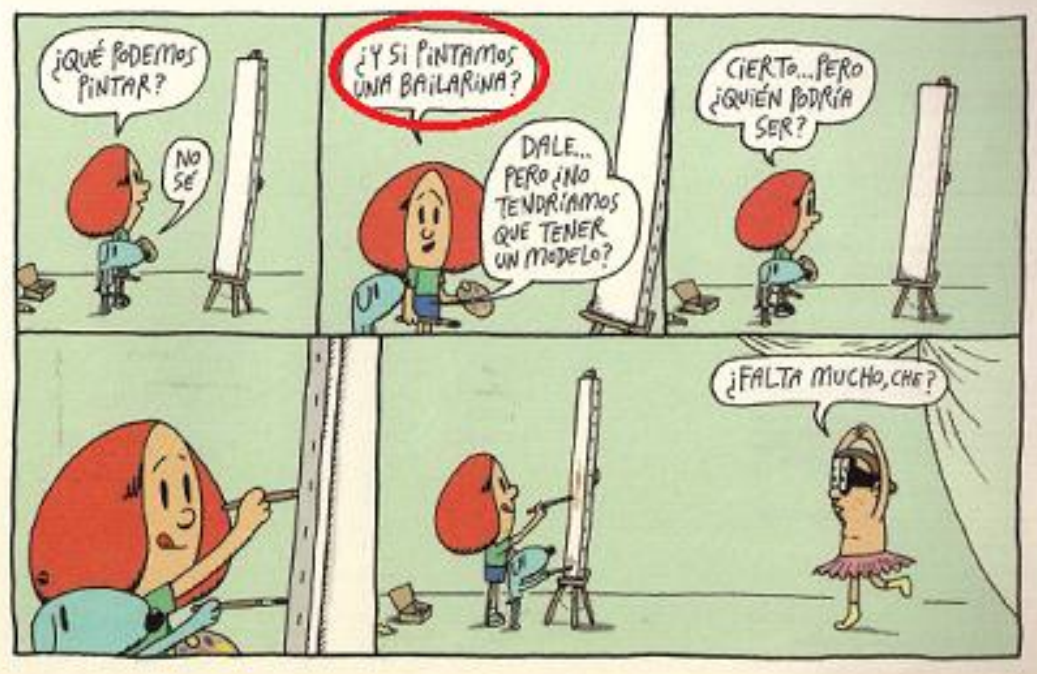

Escreva, em português, uma versão de cada uma das falas dos personagens da tirinha:

1) ¿Qué podemos pintar?

2) No sé

3) ¿Y si pintamos una bailarina?

4) Dale... Pero ino tendríamosque tener un modelo?

5) Cierto... Pero ¿quién podría ser?

6) ¿Falta mucho, che?

Relate, em português, o que você a ca ba de ler. 


\section{Quadros}

Quadro 1: Tipos de Contexto em relação a Tipos de Orientação Pragmática

\begin{tabular}{|l|l|}
\hline \multicolumn{1}{|c|}{ Tipos de Contexto } & \multicolumn{1}{c|}{ Orientações da pragmática } \\
\hline Co-textual & Do texto \\
\hline Existencial & Lógica indicial \\
\hline Situacional & "mundos possíveis" \\
\hline Acional & Orientada sociologicamente \\
\hline Psicológica & Teoria dos atos de fala \\
\hline
\end{tabular}

Fonte: PARRET (1984)

Quadro 2: Esquema apresentado por Ibañez

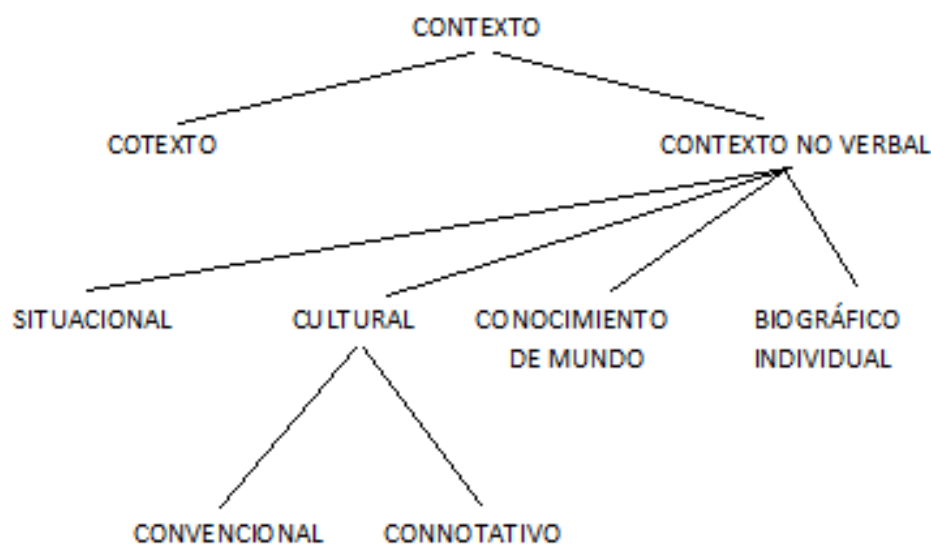

Fonte: IBAÑEZ (1990, p.8) 
Quadro 3: Componentes do contexto

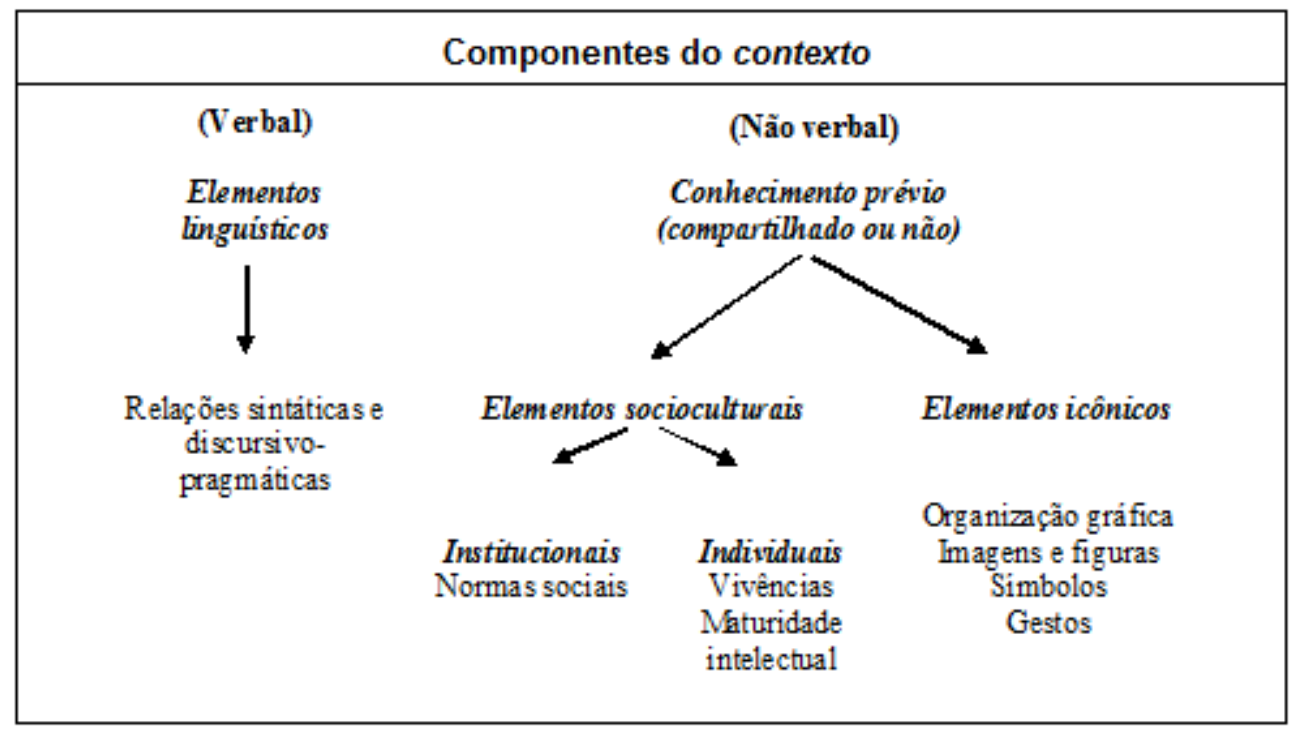

Fonte: Elaborado pela autora

Quadro 4: Síntese de nosso entendimento sobre " $Y$ si"

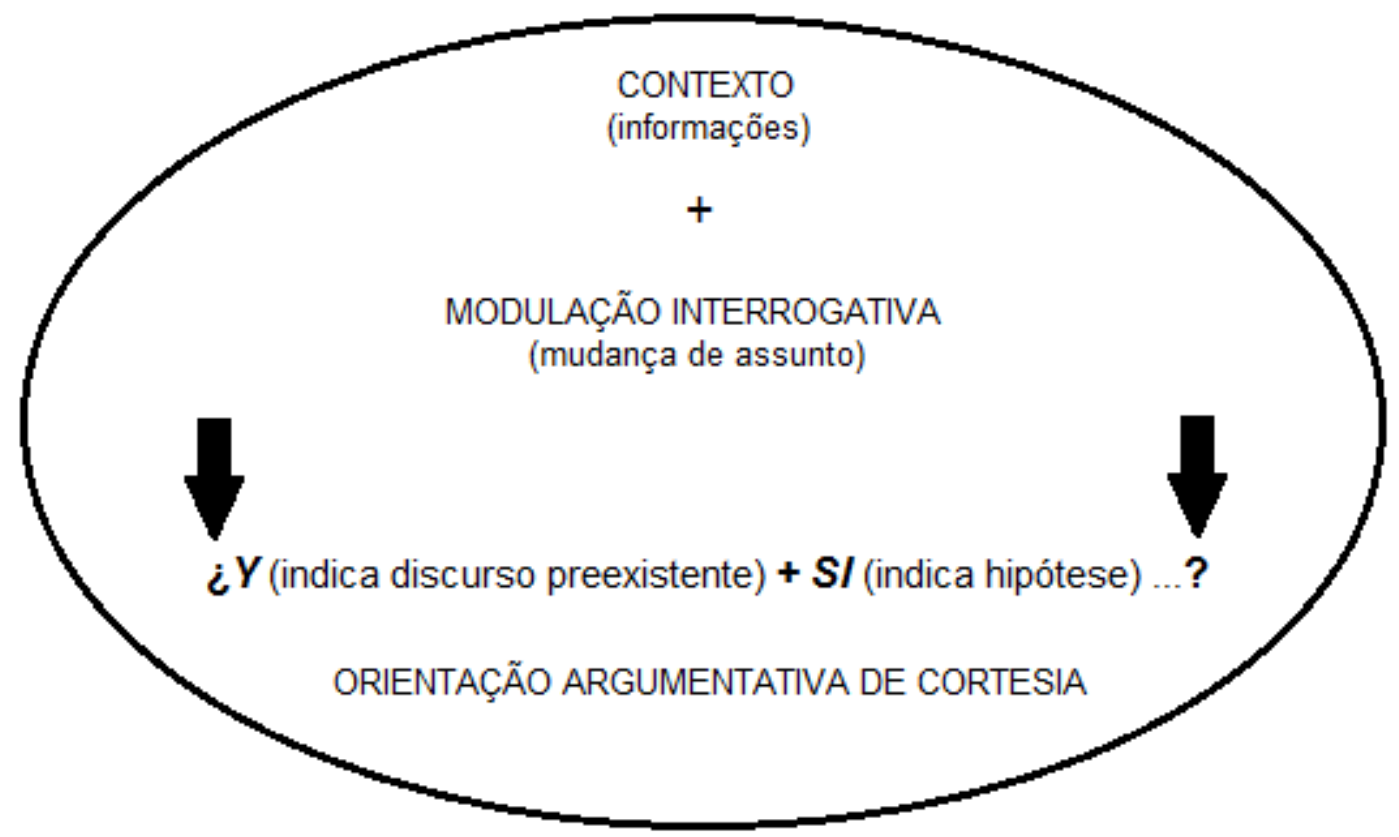

Fonte: Elaborado pela autora 
Quadro 5: Compilação de respostas para a Tirinha 1

Quadro 5 - Compilação de respostas para a Tirinha 1

(organizado por idade, na categoria - Ensino Médio / Universitário)

\begin{tabular}{|c|c|c|c|}
\hline $\begin{array}{c}\text { Código } \\
\text { Informante }\end{array}$ & Idade & Falas & Relato \\
\hline G1-EM-002 & 15 & $\begin{array}{l}\text { _Os piratas nos apontam com } \\
\text { seus canhões! } \\
\text { _Nós não temos armas! } \\
\text { _Na água tem tubarão! } \\
\text { _O que fazemos capitão? } \\
\text { _E se jogarmos a outra coisa? }\end{array}$ & $\begin{array}{l}\text { Tem um barco normal com } 3 \text { tripulantes, } \\
\text { o capitão avista um outro barco com } \\
\text { canhões apontado para eles. Um dos } \\
\text { seus tripulantes pergunta o que eles vão } \\
\text { fazer já que não tem armas, o outro fala } \\
\text { "e se jogarmos a outra coisa? Essa outra } \\
\text { coisa poderia ser o capitão pra distrair os } \\
\text { tubarões e saírem nadando. }\end{array}$ \\
\hline G1-EM-005 & 15 & $\begin{array}{l}\text { _Os piratas nos apontam com } \\
\text { seus canhões } \\
\text { _Nós não temos armas } \\
\text { _E na água tem tubarões } \\
\text { _O que fazemos capitão? } \\
\text { _E se jogarmos a outra coisa? }\end{array}$ & $\begin{array}{l}\text { São "piratas" (amigos) que não têm } \\
\text { arma sendo alvo de piratas com arma, na } \\
\text { água há tubarões e Boris opina em jogar } \\
\text { (jugamos) outra coisa (cosa) neles; talvez } \\
\text { jogar o piratas para os tubarões. }\end{array}$ \\
\hline G1-EM-010 & 15 & $\begin{array}{l}\text { _Os piratas nos apontam com } \\
\text { seus canhões! } \\
\text { _Nós não temos armas! } \\
\text { _I na água tem tubarões! } \\
\text { _Que fazemos, capitão? } \\
\text { _I si jogarmos outra coisa? }\end{array}$ & $\begin{array}{l}\text { Eu li uma história que piratas estão } \\
\text { começando a atacar eles e o cachorro } \\
\text { fala que eles não tem armas e que na } \\
\text { água tem muitos tubarões, e ele } \\
\text { pergunta o que vai fazer pro capitão e o } \\
\text { capitão fala que pode jogar outra coisa. }\end{array}$ \\
\hline G1-EM-021 & 15 & $\begin{array}{l}\text { _Os piratas estão apontando com } \\
\text { seus canhões! } \\
\text { _Nós não temos armas! } \\
\text { _E na água há tubarões } \\
\text { _O que fazemos capitão? } \\
\text { _E se jogarmos outra coisa? }\end{array}$ & $\begin{array}{l}\text { Um grupo de amigos, incluindo o } \\
\text { cachorro, estão vendo um navio pirata } \\
\text { apontando vários canhões para eles. } \\
\text { Eles tentam achar uma solução. Não } \\
\text { podem abandonar o navio, pois na água } \\
\text { tem vários tubarões, e eles não tem } \\
\text { armas. E então perguntam para o } \\
\text { capitão se poderiam jogar outra coisa }\end{array}$ \\
\hline G1-EM-024 & 15 & $\begin{array}{l}\text { _os piratas apontam com seus } \\
\text { telescópios } \\
\text { _os outros não tem armas } \\
\text { _tem água nos canhões } \\
\text { _o que fazemos capitão? } \\
\text { _e sim jogamos outra coisa? }\end{array}$ & $\begin{array}{l}\text { Que eles estão cercados de tubarões e } \\
\text { tem água nos canhões e pede ajuda para } \\
\text { o capitão e pergunta: O que fazemos } \\
\text { agora capitão? } \\
\text { capitão responde: sim jogamos outra } \\
\text { coisa! } \\
\text { Continua... }\end{array}$ \\
\hline
\end{tabular}




\begin{tabular}{|c|c|c|c|}
\hline $\begin{array}{c}\text { Código } \\
\text { Informante }\end{array}$ & Idade & Falas & Relato \\
\hline G1-EM-028 & 15 & $\begin{array}{l}\text { _Os piratas nos apontam com } \\
\text { seus canhões } \\
\text { _Nós não temos armas! } \\
\text { _E na água há tubarões } \\
\text { _O que fazemos, capitão? } \\
\text { _E se jogarmos outra coisa? }\end{array}$ & $\begin{array}{l}\text { Eles estavam em um conflito com outro } \\
\text { navio, porém eles não tem armas e a } \\
\text { água está cheia de tubarões, eles entram } \\
\text { em dúvida no que fazer, aí um cachorro } \\
\text { pergunta se não podem jogar outra } \\
\text { coisa, como os tubarões. }\end{array}$ \\
\hline G1-EM-004 & 16 & $\begin{array}{l}\text { _Os piratas apontam com seus } \\
\text { canhões! } \\
\text { _Nós não temos armas! } \\
\text { _Na água tem tubarões! } \\
\text { _O que fazemos capitão? } \\
\text { _e se jogarmos outra coisa? }\end{array}$ & $\begin{array}{l}\text { Há dois tripulantes no navio e aponta } \\
\text { outro navio pirata com seus canhões. Os } \\
\text { dois tripulantes não tem armas e eles } \\
\text { veem que na água há tubarões. Um } \\
\text { deles pergunta o que fazer e o outro da } \\
\text { uma sugestão. }\end{array}$ \\
\hline G1-EM-006 & 16 & $\begin{array}{l}\text { _Os piratas nos apontaram seus } \\
\text { canhões. } \\
\text { _Nós não temos armas. } \\
\text { _E na água tem tubarões. } \\
\text { _Que fazemos, capitão? } \\
\text { _E se jogarmos outra coisa? }\end{array}$ & $\begin{array}{l}\text { Os piratas tinham apontado um canhão } \\
\text { para Batu, seu cachorro Tútum e seu } \\
\text { amigo Boris, mas eles não tinham armas } \\
\text { e não sabiam o que fazer, pois na água } \\
\text { tinha tubarões. Então, eles se } \\
\text { perguntaram o que devem fazer, e sem } \\
\text { saber o que fazer, sugerem jogar outra } \\
\text { coisa. }\end{array}$ \\
\hline G1-EM-007 & 16 & $\begin{array}{l}\text { _Os piratas nos apontarão seus } \\
\text { canhões! } \\
\text { _Nós não temos nenhuma arma! } \\
\text { _E na água tem tubarões! } \\
\text { _O que fazemos capitão? } \\
\text { _E se jogarmos outra coisa? }\end{array}$ & $\begin{array}{l}\text { Batu: Os piratas nos aponta com seus } \\
\text { canhões! } \\
\text { Tutum: Nós não temos nenhuma arma! } \\
\text { Tutum: E a água tem tubarões } \\
\text { Tutum: O que fazemos capitão? } \\
\text { Boris: E se jogarmos outra coisa? }\end{array}$ \\
\hline G1-EM-012 & 16 & $\begin{array}{l}\text { _Os piratas nos apontaram seus } \\
\text { canhões } \\
\text { _Nós não temos armas } \\
\text { _E há tubarões na água } \\
\text { _O que fazemos, capitão } \\
\text { _E se jogarmos outra coisa? }\end{array}$ & $\begin{array}{l}\text { Duas crianças e um cachorro estavam } \\
\text { velejando e se depararam com piratas } \\
\text { que apontavam canhões para eles. O } \\
\text { cachorro então os lembra que não } \\
\text { possuem armas e estão cercados por } \\
\text { tubarões, um dos marinheiros então } \\
\text { sugere que mudem de brincadeira. }\end{array}$ \\
\hline G1-EM-015 & 16 & $\begin{array}{l}\text { _Os piratas nos apontam com } \\
\text { seus canhões! } \\
\text { _Nós não temos armas! } \\
\text { _E na água tem tubarões } \\
\text { _O que fazemos, capitão? } \\
\text { _E se jogarmos outra coisa? }\end{array}$ & $\begin{array}{l}\text { Os piratas estão apontando seus } \\
\text { "canhões" para o barco de Batu, e o } \\
\text { cãozinho observa que eles não tem } \\
\text { armas, e na água tem tubarões, porém o } \\
\text { menino de óculos questiona se eles não } \\
\text { viram errado. }\end{array}$ \\
\hline G1-EM-016 & 16 & $\begin{array}{l}\text { _Os piratas miram seus canhões } \\
\text { para nós! } \\
\text { _Nós não temos armas! } \\
\text { _E na água tem tubarões! } \\
\text { _O que fazemos, capitão? } \\
\text { _E se brincarmos de outra coisa? }\end{array}$ & $\begin{array}{l}\text { Dois meninos e um cão brincam de } \\
\text { piratas e marinheiros, quando se } \\
\text { encontram em uma silada, sem armas e } \\
\text { com tubarões em sua volta um deles } \\
\text { sugere que mudem de brincadeira. } \\
\text { Continua... }\end{array}$ \\
\hline
\end{tabular}




\begin{tabular}{|c|c|c|c|}
\hline $\begin{array}{c}\text { Código } \\
\text { Informante }\end{array}$ & Idade & Falas & Relato \\
\hline G1-EM-019 & 16 & $\begin{array}{l}\text { _Os piratas nos apontam os seus } \\
\text { canhões! } \\
\text { _Nós não temos armas! } \\
\text { _E na água há tubarões! } \\
\text { _Que fazemos, capitão? } \\
\text { _E se jogarmos outra coisa? }\end{array}$ & $\begin{array}{l}\text { Eu entendi que o Batu é o capitão e o } \\
\text { tútum e o Boris são os marinheiros. Eles } \\
\text { estão navegando, quando um navio } \\
\text { pirata aponta os canhões para eles, eles } \\
\text { sem armas e sem saber o que fazer, } \\
\text { pensam em até pular na água mais está } \\
\text { cheia de tubarões, então Boris pergunta } \\
\text { "e se jogarmos outra coisa". }\end{array}$ \\
\hline G1-EM-020 & 16 & $\begin{array}{l}\text { _Os piratas nos apontam o } \\
\text { canhão. } \\
\text { _Nós não temos arma. } \\
\text { _Na água tem tubarões. } \\
\text { _O que fazemos capitão? } \\
\text { _E se jogarmos outra coisa. }\end{array}$ & $\begin{array}{l}\text { Os piratas apontam o canhão! } \\
\text { Nós não temos armas! } \\
\text { Na água há tubarões. } \\
\text { O que fazemos capitão? } \\
\text { E se jogarmos outra coisa? }\end{array}$ \\
\hline G1-EM-030 & 17 & $\begin{array}{l}\text { _Os piratas estão nos apontando } \\
\text { seus canhões. } \\
\text { _Não temos armas. } \\
\text { _E na água há tubarões } \\
\text { _O que faremos, capitão. } \\
\text { _E se jogarmos uma outra coisa? }\end{array}$ & $\begin{array}{l}\text { Um navio esta sendo atacado por } \\
\text { piratas, eles ficam preocupados por não } \\
\text { terem armas para se defender, não } \\
\text { podem escapar pela água pois há } \\
\text { tubarões, perguntam ao capitão sobre o } \\
\text { que fazemos e ele sugere jogar qualquer } \\
\text { outra coisa para se defender. }\end{array}$ \\
\hline G1-EM-017 & 18 & $\begin{array}{l}\text { _Os piratas nos apontam com } \\
\text { seus canhões } \\
\text { _Nós não temos armas } \\
\text { _E na água tem tubarões } \\
\text { _Que fazemos capitão } \\
\text { E se jogarmos outra coisa }\end{array}$ & $\begin{array}{l}\text { Um quadrinho que relata que tem dois } \\
\text { barcos um contém piratas apontando } \\
\text { canhões para um desarmado e as águas } \\
\text { tem tubarões. }\end{array}$ \\
\hline G1-EM-026 & 18 & $\begin{array}{l}\text { _o que personagens piratas } \\
\text { _Não sei } \\
\text { _E se pintarmos uma bailarina } \\
\text { _Batu } \\
\text { Não sei }\end{array}$ & $\begin{array}{l}\text { Uma narração entre piratas } \\
\text { DESCONSIDERADO }\end{array}$ \\
\hline G1-UN-005 & 19 & $\begin{array}{l}\text { _Os piratas nos apontam com } \\
\text { seus canhões! } \\
\text { _Nós não temos armas! } \\
\text { _E na água tem tubarões! } \\
\text { _Que fazemos, capitão? } \\
\text { _E se jogarmos outra coisa? }\end{array}$ & $\begin{array}{l}\text { Acabo de ler uma tirinha que contêm } \\
\text { três personagens dialogando em um } \\
\text { barco em alto mar. Eles conversam a } \\
\text { respeito de um possível ataque que } \\
\text { sofrerão. Um dos personagens é um } \\
\text { cachorro que argumenta não terem } \\
\text { armas para revidar o ataque, ao que o } \\
\text { outro personagem sugere uma nova } \\
\text { solução ao capitão. } \\
\text { Continua... }\end{array}$ \\
\hline
\end{tabular}




\begin{tabular}{|c|c|c|c|}
\hline $\begin{array}{c}\text { Código } \\
\text { Informante }\end{array}$ & Idade & Falas & Relato \\
\hline G1-UN-009 & 19 & $\begin{array}{l}\text { _Os piratas nos apontaram com } \\
\text { seus canhões! } \\
\text { _Nós não temos armas! } \\
\text { _E na água há tubarões! } \\
\text { _O que fazemos, capitão? } \\
\text { _E se jogarmos a outra coisa? }\end{array}$ & $\begin{array}{l}\text { Uma história na qual um menino e seu } \\
\text { cachorro estavam em um barco e então } \\
\text { alguns piratas os ameaçaram com seus } \\
\text { canhões, eles não sabiam o que fazer, o } \\
\text { cachorro disse que a água havia } \\
\text { tubarões e então estavam sem saída } \\
\text { então o menino deu a ideia de jogarem } \\
\text { outra coisa. }\end{array}$ \\
\hline G1-UN-007 & 20 & $\begin{array}{l}\text { _Os piratas estão apontando seus } \\
\text { canhões para gente! } \\
\text { _Nós não temos armas! } \\
\text { _E há tubarões na água! } \\
\text { _O que faremos, capitão? } \\
\text { _E se brincarmos de outra coisa? }\end{array}$ & $\begin{array}{l}\mathrm{Na} \text { tirinha mostrada acima, três } \\
\text { personagens estão em uma brincadeira } \\
\text { onde simulam estarem em alto mar, } \\
\text { cercados por tubarões e perseguidos por } \\
\text { piratas. } \\
\text { Após os relatos dos perigos que estão } \\
\text { correndo na brincadeira, um dos } \\
\text { personagens indaga o que eles deverão } \\
\text { fazer em relação aos perigos. Então, um } \\
\text { dos personagens sugere que troquem de } \\
\text { brincadeira. }\end{array}$ \\
\hline G1-UN-004 & 25 & $\begin{array}{l}\text { _Os piratas nos ameaçam com } \\
\text { seus canhões! } \\
\text { _Nós não possuímos armas! } \\
\text { _E na água tem tubarões! } \\
\text { _O que faremos, capitão? } \\
\text { _E se atirarmos outra coisa? }\end{array}$ & $\begin{array}{l}\text { A história se passa em alto mar, Batu } \\
\text { está olhando com uma "luneta" e } \\
\text { percebe que há piratas que estão } \\
\text { mirando seus canhões para eles. O } \\
\text { cachorro azul avisa que eles não } \\
\text { possuem armas para se defenderem e } \\
\text { não podem pular no mar porque há } \\
\text { tubarões na água. O cachorrinho } \\
\text { pergunta ao capitão o que irão fazer, e } \\
\text { ele responde se não eles não podem } \\
\text { jogar outra coisa. }\end{array}$ \\
\hline G1-UN-011 & 27 & $\begin{array}{l}\text { _Os piratas apontam seus } \\
\text { canhões! } \\
\text { _Nós não temos armas! } \\
\text { _E na água tem tubarões } \\
\text { _O que fazemos, capitão? } \\
\text { _E se jogarmos a outra coisa? }\end{array}$ & $\begin{array}{l}\text { Dois garotos e um cãozinho estão } \\
\text { brincando que são piratas. Para deixar a } \\
\text { brincadeira mais emocionante, Batu, o } \\
\text { menino de cabelos ruivos, diz que avista } \\
\text { alguns piratas que estão armados e, } \\
\text { como na "embarcação" que os meninos } \\
\text { estão não possui armas e no "mar" } \\
\text { existem tubarões, a melhor solução } \\
\text { encontrada por Boris, o amigo de Batu, é } \\
\text { perguntar se eles não podem trocar de } \\
\text { brincadeira. }\end{array}$ \\
\hline
\end{tabular}

Fonte: Elaborado pela autora 
Quadro 6: Construção de efeito de sentido versus elemento icônico- Tirinha 1

\begin{tabular}{|c|c|c|c|c|c|}
\hline \multicolumn{6}{|c|}{ Quadro 6 - Construção de efeito de sentido versus elemento icônico na Tirinha 1} \\
\hline $\begin{array}{r}\begin{array}{r}\text { Elemento } \\
\text { icônico }\end{array} \\
\text { Efeito de } \\
\text { sentido }\end{array}$ & $\begin{array}{c}\text { Apagamento } \\
\text { de Batu }\end{array}$ & $\begin{array}{l}\text { Boris como } \\
\text { capitão }\end{array}$ & $\begin{array}{c}\text { Tútum } \\
\text { como } \\
\text { enunciador }\end{array}$ & $\begin{array}{c}\text { Não } \\
\text { identificação } \\
\text { dos } \\
\text { personagens }\end{array}$ & $\begin{array}{c}\text { Identificação } \\
\text { dos } \\
\text { personagens }\end{array}$ \\
\hline $\begin{array}{l}\text { Sugestão } \\
\text { (mudar de } \\
\text { brincadeira) }\end{array}$ & & & & & $\begin{array}{l}\text { G1-EM-012 } \\
\text { G1-EM-016 } \\
\text { G1-UN-007 } \\
\text { G1-UN-011 }\end{array}$ \\
\hline $\begin{array}{l}\text { Sugestão } \\
\text { (ambígua) }\end{array}$ & G1-UN-009 & & & & G1-EM-006 \\
\hline $\begin{array}{c}\text { Sugestão } \\
\text { (arremessar) }\end{array}$ & & $\begin{array}{l}\text { G1-EM-030 } \\
\text { G1-UN-004 }\end{array}$ & & G1-EM-005 & G1-EM-002 \\
\hline $\begin{array}{l}\text { Sugestão (sem } \\
\text { ação especifica) }\end{array}$ & G1-EM-004 & & & & G1-UN-005 \\
\hline $\begin{array}{l}\text { Autorização } \\
\text { (dada ou } \\
\text { solicitada) }\end{array}$ & & $\begin{array}{l}\text { G1-EM-010 } \\
\text { G1-EM-024 }\end{array}$ & G1-EM-028 & & G1-EM-021 \\
\hline $\begin{array}{c}\text { Dúvida ou } \\
\text { questionamento }\end{array}$ & & & & & G1-EM-015 \\
\hline Não identificado & & & & $\begin{array}{l}\text { G1-EM-007 } \\
\text { G1-EM-017 } \\
\text { G1-EM-020 }\end{array}$ & G1-EM-019 \\
\hline
\end{tabular}

Fonte: Elaborado pela autora 
Quadro 7: Compilação de respostas para a Tirinha 2

Quadro 7 - Compilação de respostas para a Tirinha 2

(organizado por idade, na categoria - Ensino Médio / Universitário)

\begin{tabular}{|c|c|c|c|}
\hline $\begin{array}{c}\text { Código } \\
\text { Informante }\end{array}$ & Idade & Falas & Relato \\
\hline G2-EM-001 & 15 & $\begin{array}{l}\text { _O que podemos pintar } \\
\text { _não sei } \\
\text { _E se pintarmos uma bailarina } \\
\text { _Isso. Espera não teriamos que } \\
\text { ter uma modelo } \\
\text { _Certo, espera quem poderia ser } \\
\text { _falta muito ia }\end{array}$ & $\begin{array}{l}\text { O que podemos pintar, não sei } \\
\text { e se pintarmos uma bailarina? } \\
\text { Isso espera não teriamos que ter um } \\
\text { modelo } \\
\text { Certo espera quem poderia ser } \\
\text { falta muito ai }\end{array}$ \\
\hline G2-EM-003 & 15 & $\begin{array}{l}\text { _O que podemos pintar? } \\
\text { _Não sei. } \\
\text { _E se pintarmos uma bailarina? } \\
\text { _Não teriamos que ter um } \\
\text { modelo? } \\
\text { _Certo. Quem poderia ser? } \\
\text { _Falta muito? }\end{array}$ & $\begin{array}{l}\text { Um garoto ruivo e seu cachorro estão } \\
\text { procurando e pensando no que poderão } \\
\text { pintar. O garoto sugere uma bailarina e } \\
\text { o cachorro um modelo. Então eles usam } \\
\text { seu amigo como modelo e ele está } \\
\text { bastante tempo parado. }\end{array}$ \\
\hline G2-EM-009 & 15 & $\begin{array}{l}\text { _O que podemos pintar? } \\
\text { _Não sei } \\
\text { _E se pintarmos uma bailarina? } \\
\text { _Bom, não teremos que ter um } \\
\text { modelo } \\
\text { _Certo, quem poderia ser? } \\
\text { _Falta muito? }\end{array}$ & $\begin{array}{l}\text { Um menino tem a ideia de pintar uma } \\
\text { bailarina mais não tem um modelo ai } \\
\text { resolve personalizar um menino de } \\
\text { bailarina de modelo. }\end{array}$ \\
\hline G2-EM-014 & 15 & $\begin{array}{l}\text { _O que poderemos pintar? } \\
\text { _Não sei } \\
\text { _E se pintassemos uma bailarina? } \\
\text { _Vale... Mas não teríamos que ter } \\
\text { um modelo? } \\
\text { _Certo... Mas quem poderia ser? } \\
\text { _Falta muito? }\end{array}$ & $\begin{array}{l}\text { Batu, juntamente com seu cão pensa em } \\
\text { fazer uma pintura qualquer. Ele resolve } \\
\text { então desenhar uma bailarina para isso } \\
\text { ele chamou seu amigo que se chamava } \\
\text { Boris para servir de modelo para ele } \\
\text { desenhar com a ajuda de seu cão. }\end{array}$ \\
\hline G2-EM-023 & 15 & $\begin{array}{l}\text { _O que podemos pintar? } \\
\text { _Não sei } \\
\text { _E se pintarmos uma bailarina? } \\
\text { _Isso. Espera, não teriamos que } \\
\text { ter uma modelo? } \\
\text { _Certo. Mas quem poderia ser? } \\
\text { _Falta muito? }\end{array}$ & $\begin{array}{l}\text { A garota ruiva quer pintar algo mas } \\
\text { ainda não tem ideia. Penso em pintar } \\
\text { uma bailarina porém ainda não tem uma } \\
\text { modelo. Pensando bem quem poderia } \\
\text { ser, seu amigo acaba posando ajudando } \\
\text { ela. }\end{array}$ \\
\hline G2-EM-025 & 15 & $\begin{array}{l}\text { _Que podemos pintar? } \\
\text { _Não sei } \\
\text { _E si pintamos uma bailarina? } \\
\text { _Precisamos de um modelo? } \\
\text { _Certo Boris poderá ser? } \\
\text { _Falta muito, Batu? }\end{array}$ & $\begin{array}{l}\text { Eu acabei de ler um menino ruivo } \\
\text { chamado de Batu junto com seu } \\
\text { cachorro azul onde ele quer pinta e tem } \\
\text { uma ideia de pintar uma bailarina e } \\
\text { chama seu amigo Boris para ser a } \\
\text { Bailarina onde ele aceita o convite e o } \\
\text { modelo de Batu. } \\
\text { Continua... }\end{array}$ \\
\hline
\end{tabular}




\begin{tabular}{|c|c|c|c|}
\hline $\begin{array}{c}\text { Código } \\
\text { Informante }\end{array}$ & Idade & Falas & Relato \\
\hline G2-EM-029 & 15 & $\begin{array}{l}\text { _O que podemos pintar? } \\
\text { _Não sei } \\
\text { _E se pintarmos uma bailarina? } \\
\text { _Calma... Não teriamos que ter } \\
\text { um modelo } \\
\text { _Certo... quem poderia ser? } \\
\text { _Falta muito }\end{array}$ & $\begin{array}{l}\text { Que uma menina quer fazer uma pintura } \\
\text { e precisava de um molde. }\end{array}$ \\
\hline G2-EM-008 & 16 & $\begin{array}{l}\text { _O que podemos pintar? } \\
\text { _Não sei } \\
\text { _E se pintarmos uma bailarina? } \\
\text { _Ótimo... Mas, não teríamos que } \\
\text { ter um modelo? } \\
\text { _Certo... Mas quem poderia ser? } \\
\text { _Falta muito, che? }\end{array}$ & $\begin{array}{l}\text { O menino, Batu, e seu cãozinho Tútum, } \\
\text { estão indecisos sobre o que eles devem } \\
\text { pintar. Então Batu sugere que pintem } \\
\text { uma bailarina, mas eles precisam } \\
\text { arranjar uma modelo. Então eles usam o } \\
\text { amigo de Batu, Boris, como modelo. }\end{array}$ \\
\hline G2-EM-011 & 16 & $\begin{array}{l}\text { _O que podemos pintar? } \\
\text { _Não sei. } \\
\text { _E se pintarmos uma bailarina? } \\
\text { _É... Más, não teríamos que ter } \\
\text { um modelo? } \\
\text { _Certo... Más quem poderia ser? } \\
\text { Falta muito, ainda? }\end{array}$ & $\begin{array}{l}\text { Um menino e um cachorro azul com } \\
\text { dúvidas em que ele poderia pintar, ele } \\
\text { decide pintar uma bailarina mas não } \\
\text { tinha ninguém de modelo, então decide } \\
\text { chamar alguém para servir de modelo } \\
\text { para sua pintura. }\end{array}$ \\
\hline G2-EM-013 & 16 & $\begin{array}{l}\text { _O que podemos pintar? } \\
\text { _Não sei } \\
\text { _E se pintarmos uma bailarina? } \\
\text { _Ok mas, não teriamos que ter } \\
\text { um modelo? } \\
\text { _Certo... mas, quem poderia ser? } \\
\text { _Falta muito, tempo? }\end{array}$ & $\begin{array}{l}\text { Esse quadrinho é uma menina e um } \\
\text { cachorro pintando em um quadro um } \\
\text { menino vestido de bailarina. }\end{array}$ \\
\hline G2-EM-022 & 16 & $\begin{array}{l}\text { _O que podemos pintar? } \\
\text { _Não sei } \\
\text { _E se pintarmos uma bailarina? } \\
\text { _Ótimo... Espera. Não teríamos } \\
\text { que ter um modelo? } \\
\text { _Certo. Espera. Quem poderia } \\
\text { ser? } \\
\text { _Falta muito, em? }\end{array}$ & $\begin{array}{l}\text { Um menino e seu cão queriam pintar } \\
\text { algo e o menino deu a ideia de pintarem } \\
\text { uma bailarina e seu cão pergunta se eles } \\
\text { não precisariam de um modelo ela em } \\
\text { seguida pensa quem poderia ser este } \\
\text { modelo. Em seguida aparece seu amigo } \\
\text { parado como uma bailarina } \\
\text { perguntando se ainda faltava muito para } \\
\text { terminar a pintura. }\end{array}$ \\
\hline G2-EM-027 & 16 & $\begin{array}{l}\text { _O que podemos pintar } \\
\text { _Não sei } \\
\text { _E se pintarmos uma bailarina } \\
\text { _OK precisamos de uma modelo } \\
\text { _Certo... OK quem poderia ser } \\
\text { _Falta muito ai }\end{array}$ & $\begin{array}{l}\text { Uma moça que tenta fazer uma pintura } \\
\text { de uma bailarina. }\end{array}$ \\
\hline
\end{tabular}




\begin{tabular}{|c|c|c|c|}
\hline $\begin{array}{c}\text { Código } \\
\text { Informante }\end{array}$ & Idade & Falas & Relato \\
\hline G2-EM-018 & 17 & $\begin{array}{l}\text { _O que podemos pintar? } \\
\text { _Não sei } \\
\text { _E se pintarmos uma bailarina? } \\
\text { _Para... espera. Não teriamos que } \\
\text { ter um modelo? } \\
\text { _Certo... espera. O que poderia } \\
\text { ser? } \\
\text { _Falta muito? }\end{array}$ & $\begin{array}{l}\text { Uma menina que queria pintar algo, mas } \\
\text { ela não sabe o que seria esse algo. } \\
\text { Então ela tem a ideia de pintar uma } \\
\text { bailarina, mas ela acha que precisa de } \\
\text { um modelo para conseguir concluir a sua } \\
\text { pintura. }\end{array}$ \\
\hline G2-UN-002 & 21 & $\begin{array}{l}\text { _O que podemos pintar? } \\
\text { _Não sei. } \\
\text { _E se pintarmos uma bailarina? } \\
\text { _Mas não teríamos que ter um } \\
\text { modelo? } \\
\text { _Certo... Mas quem poderia ser? } \\
\text { _Falta muito? }\end{array}$ & $\begin{array}{l}\text { Um garoto e seu cachorro queriam } \\
\text { pintar alguma coisa. O garoto pergunta } \\
\text { ao cachorro se ele tem alguma ideia e ele } \\
\text { responde que não. Então o garoto dá a } \\
\text { ideia de pintarem uma bailarina e o } \\
\text { cachorro diz que que para isso eles } \\
\text { precisariam de um modelo. O garoto } \\
\text { pergunta quem poderia ser o modelo e, } \\
\text { então, o modelo foi um outro menino } \\
\text { que parecia estar desconfortável com a } \\
\text { situação e que pergunta se ainda faltava } \\
\text { muito para acabarem. }\end{array}$ \\
\hline G2-UN-006 & 22 & $\begin{array}{l}\text { _O que podemos pintar? } \\
\text { _Não sei. } \\
\text { _E se pintarmos uma bailarina? } \\
\text { _Sim... Mas não teríamos que ter } \\
\text { um modelo? } \\
\text { _Certo... Mas quem poderia ser? } \\
\text { _Falta muito, che? }\end{array}$ & $\begin{array}{l}\text { A menina estava sem ideias do que } \\
\text { pintar, aí ela resolveu pintar uma } \\
\text { bailarina e para isso ela queria (o } \\
\text { cachorrinho deu a ideia de arrumar um } \\
\text { modelo) um modelo. No fim, ela } \\
\text { acabava arrumando um amigo para ser } \\
\text { modelo. O amigo dela fala se falta muito } \\
\text { p/ pintar no último quadrinho. O que } \\
\text { provoca humor na tira é o fato da } \\
\text { modelo ser homem, sendo que o } \\
\text { esperado era para ser uma mulher. }\end{array}$ \\
\hline G2-UN-003 & 27 & $\begin{array}{l}\text { _O que podemos pintar? } \\
\text { _Não sei } \\
\text { _E se pintarmos uma bailarina? } \\
\text { _Claro! Espera. Não teríamos que } \\
\text { ter um modelo? } \\
\text { _Certo. Para quem poderia ser? } \\
\text { _Você, falta muito? }\end{array}$ & $\begin{array}{l}\text { Batú quer saber o que ele e seu cãozinho } \\
\text { azul tuntúm poderiam pintar. Seu } \\
\text { cachorrinho não sabia. Batú deu ideia de } \\
\text { pintar uma bailarina. E o tuntum deu } \\
\text { ideia para os dois terem um modelo de } \\
\text { bailarina e começaram a pintar uma } \\
\text { bailarina com uma modelo e o modelo } \\
\text { perguntou se falta muito para Batú e seu } \\
\text { cãozinho acabarem. } \\
\text { Continua... }\end{array}$ \\
\hline
\end{tabular}




\begin{tabular}{|c|c|c|c|}
\hline $\begin{array}{c}\text { Código } \\
\text { Informante }\end{array}$ & Idade & Falas & Relato \\
\hline G2-UN-001 & 30 & $\begin{array}{l}\text { _O que podemos desenhar? } \\
\text { _Não sei. } \\
\text { _E se desenharmos uma árvore? } \\
\text { _Vamos... Mas, não precisávamos } \\
\text { ter uma como modelo? } \\
\text { _Certo... Vamos procurar uma? } \\
\text { _Falta muito para acharmos? }\end{array}$ & $\begin{array}{l}\text { Um menino pergunta para seu } \\
\text { companheiro, um cãozinho. O que eles } \\
\text { poderiam pintar? E o cãozinho não } \\
\text { sabia. Então tiveram a ideia de pintar } \\
\text { uma bailarina, mas eles imaginaram que } \\
\text { deveriam ter um modelo. Então um } \\
\text { amigo foi o modelo de bailarina para a } \\
\text { pintura. E ele no fim perguntou se iria } \\
\text { demorar muito ainda. }\end{array}$ \\
\hline G2-UN-010 & 33 & $\begin{array}{l}\text { _O que poderíamos pintar? } \\
\text { _Não sei } \\
\text { _E se pintássemos uma bailarina? } \\
\text { _Muito bom... Mas, não } \\
\text { precisamos antes, ter um } \\
\text { modelo? } \\
\text { _É verdade... Mas, quem poderia } \\
\text { ser? } \\
\text { _Falta muito, Batu? }\end{array}$ & $\begin{array}{l}\text { A tirinha fala sobre um garoto e seu } \\
\text { cãozinho, que estavam brincando de } \\
\text { pintores; mas antes de começarem a } \\
\text { brincadeira conversaram para decidir o } \\
\text { que iriam pintar. } \\
\text { Após a conversa, decidiram que fariam a } \\
\text { pintura de uma bailarina. } \\
\text { O cãozinho, muito esperto, achou } \\
\text { melhor que fizessem a pintura a partir de } \\
\text { um modelo; como não sabiam quem } \\
\text { poderia ajudá-los, contaram com o } \\
\text { auxílio do amigo Boris, mas que não } \\
\text { parecia muito confortável na posição de } \\
\text { um bailarino. }\end{array}$ \\
\hline G2-UN-008 & 48 & $\begin{array}{l}\text { O que podemos pintar? } \\
\text { Não sei. } \\
\text { E si pintarmos uma bailarina? } \\
\text { Ok... Mas, não teríamos que ter } \\
\text { um modelo? } \\
\text { Certo... Mas quem poderia ser? } \\
\text { Falta muito?! }\end{array}$ & $\begin{array}{l}\text { Acabo de ler uma tirinha cômica que se } \\
\text { passa com uma menina e seu cão a } \\
\text { pintar uma tela. Sem saber o que pintar } \\
\text { ela sugere ao cão para que eles } \\
\text { pintassem uma bailarina. O cão sugere } \\
\text { ter um modelo vivo. Ela concorda e } \\
\text { assim o amigo da menina se veste de } \\
\text { bailarina. }\end{array}$ \\
\hline
\end{tabular}

Fonte: Elaborado pela autora 
Quadro 8: Construção de efeito de sentido versus elemento icônico- Tirinha 2

\begin{tabular}{|c|c|c|c|c|}
\hline \multicolumn{5}{|c|}{ Quadro 8 - Construção de efeito de sentido versus elemento icônico na Tirinha 2} \\
\hline $\begin{array}{r}\text { Elemento } \\
\text { icônico }\end{array}$ & $\begin{array}{l}\text { Batu visto } \\
\text { como menina }\end{array}$ & $\begin{array}{l}\text { Identificação de } \\
\text { somente dois } \\
\text { personagens }\end{array}$ & $\begin{array}{c}\text { Não } \\
\text { identificação } \\
\text { dos } \\
\text { personagens }\end{array}$ & $\begin{array}{l}\text { Identificação } \\
\text { dos } \\
\text { personagens }\end{array}$ \\
\hline Sugestão & $\begin{array}{l}\text { G2-UN-008 } \\
\text { G2-EM-023 } \\
\text { G2-EM-018 }\end{array}$ & & & $\begin{array}{l}\text { G2-EM-003 } \\
\text { G2-EM-008 } \\
\text { G2-EM-022 } \\
\text { G2-EM-025 } \\
\text { G2-UN-001 } \\
\text { G2-UN-002 } \\
\text { G2-UN-003 }\end{array}$ \\
\hline Decisão & G2-UN-006 & & & $\begin{array}{l}\text { G2-EM-011 } \\
\text { G2-EM-014 }\end{array}$ \\
\hline $\begin{array}{c}\text { Acordo / } \\
\text { negociação }\end{array}$ & & & & G2-UN-010 \\
\hline Não identificado & $\begin{array}{l}\text { G2-EM-013 } \\
\text { G2-EM-027 } \\
\text { G2-EM-029 }\end{array}$ & & G2-EM-001 & \\
\hline
\end{tabular}

Fonte: Elaborado pela autora 


\section{ANEXO}

\section{Tirinhas}

\section{Tirinha 1}

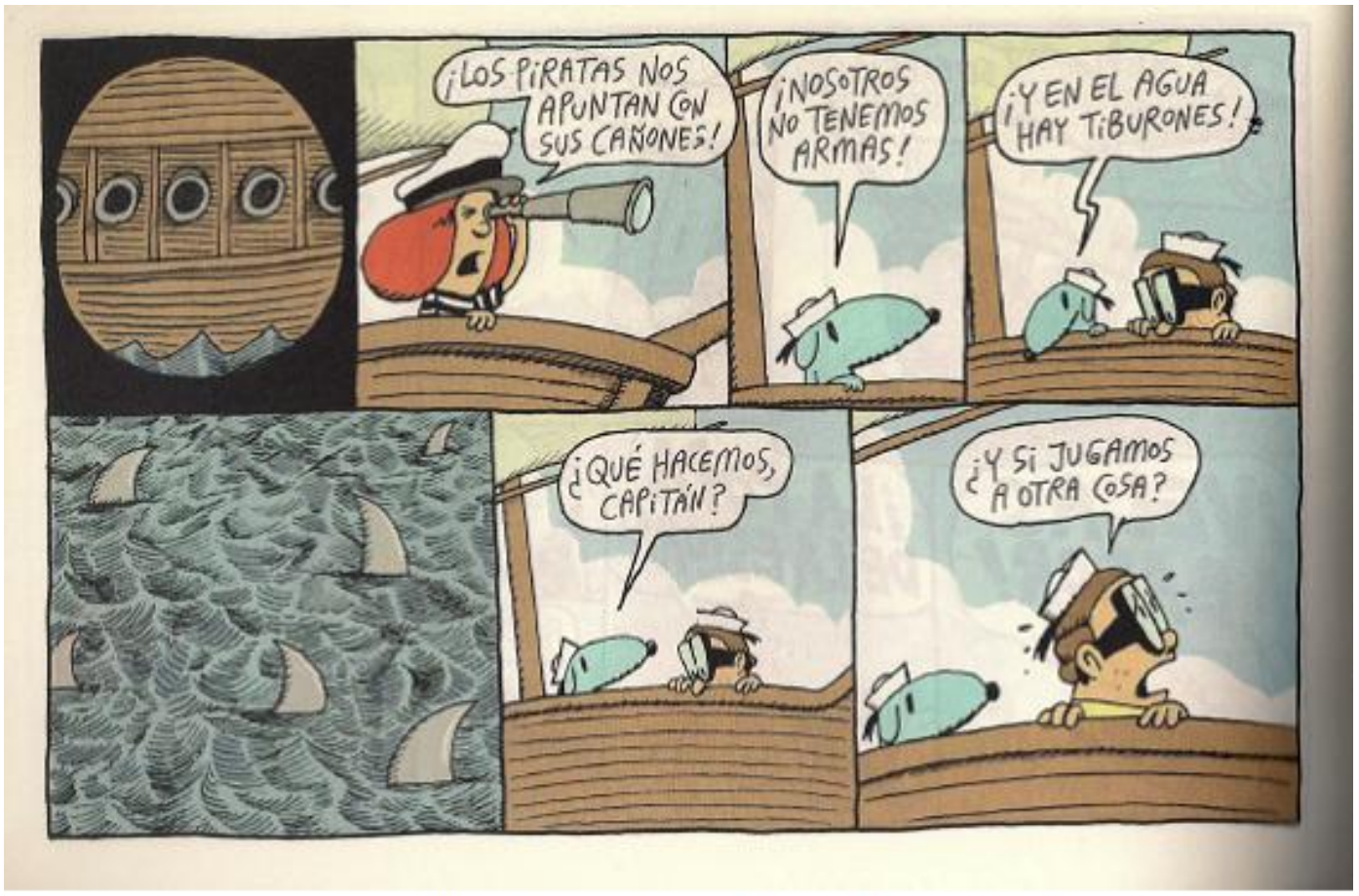

TUTE. Batu. Buenos Aires: Sudamericana, 2009.

Tirinha 2

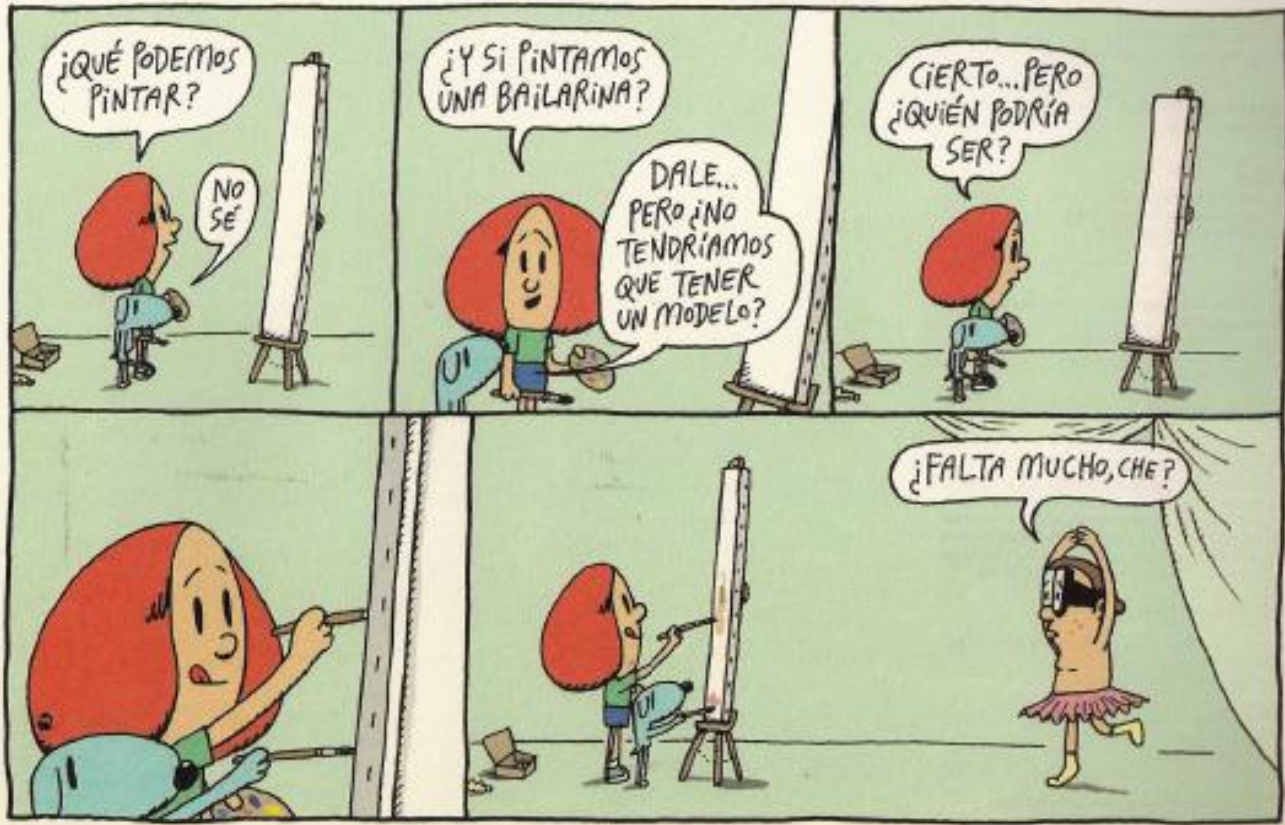

TUTE. Batu. Buenos Aires: Sudamericana, 2009. 